\title{
أسباب تدني نتائج طلاب وطالبات المرحلتين الابتدائية والمتوسطة في الاختبارات التحصيلية (المركزية) \\ بمنطقة الباحة
}

$$
\text { (دراسة ميدانية) }
$$

إعداد

\footnotetext{
دام دوفق علي الغامدي

دكتور اه الفلسفة في التربية

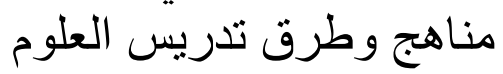

الإدارة العامة للتعليم بمنطقة الباحة
}

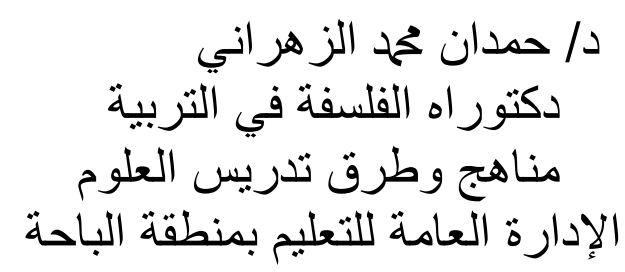

2021 


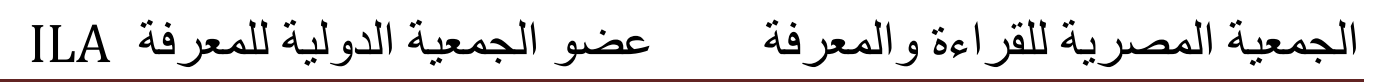

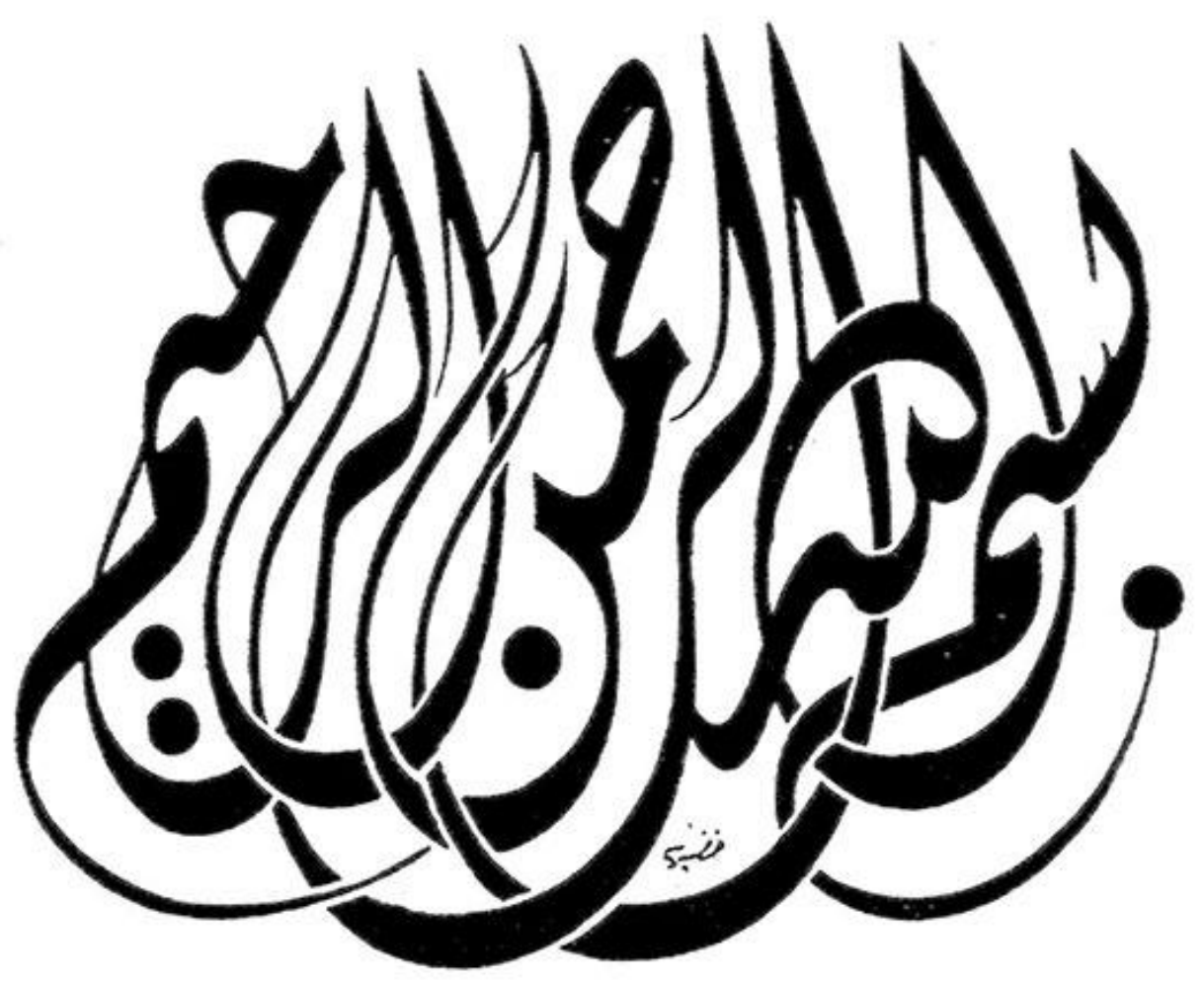




\section{المستخلص}

هدف هذا البحث إلى تعرّف أساب تدني نتائج طلاب وطالبات المرحلتين الابتدائية والمتوسطة في

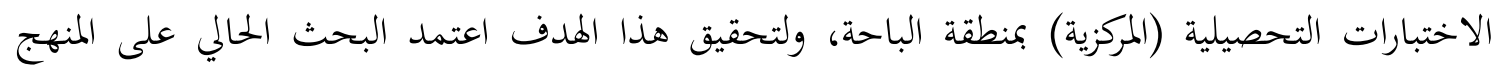

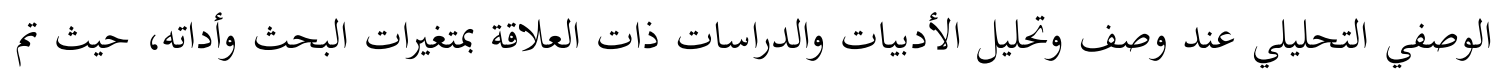

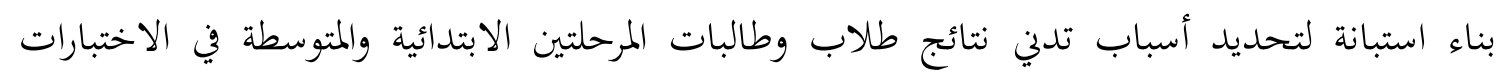

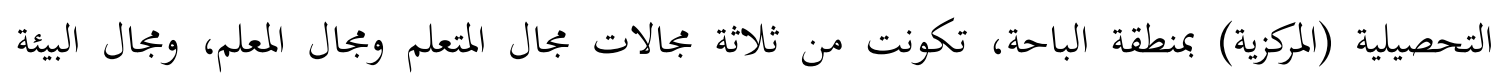

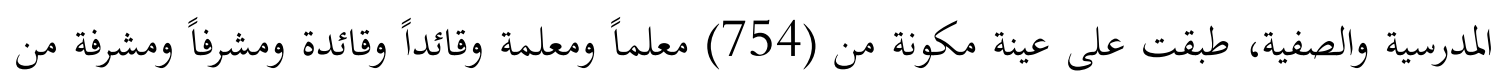

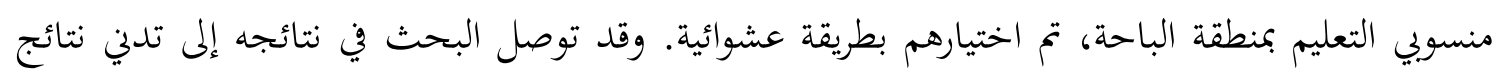

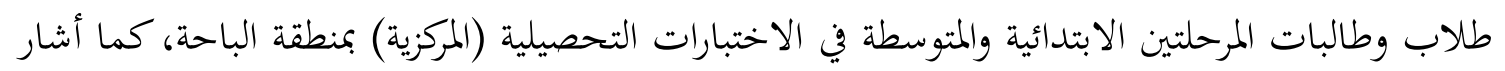

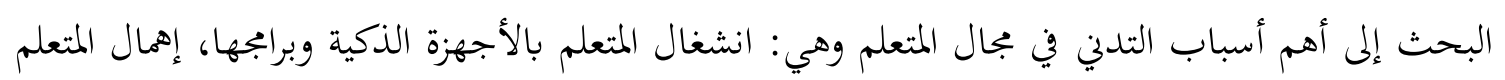

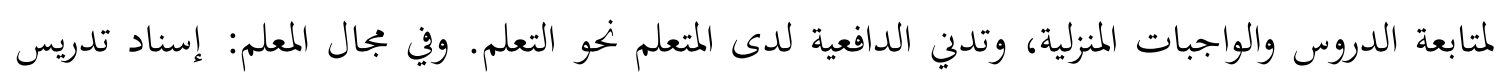

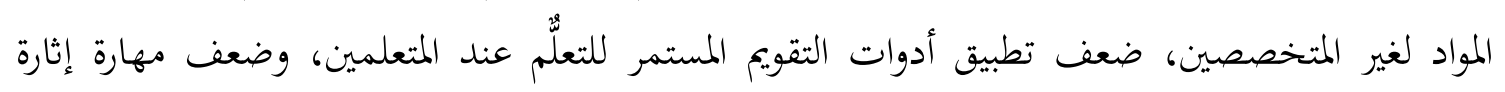

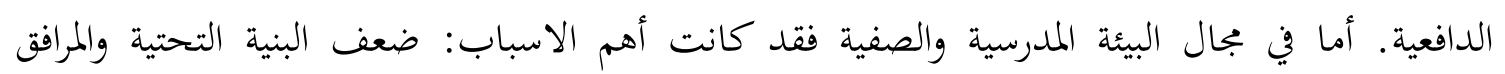

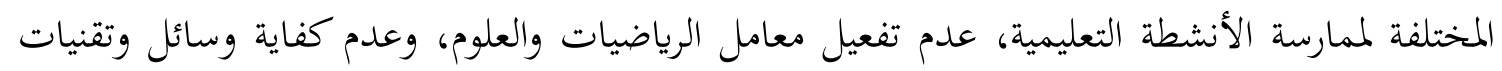

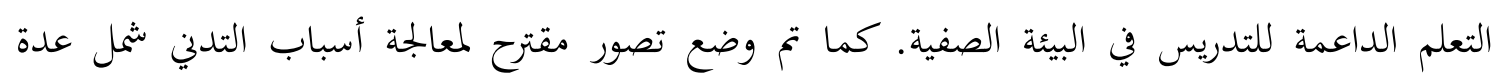
إجراءات على مستوى المدرسة، ومكتب التعليه، وعلى مستوى إدارة التعليم.

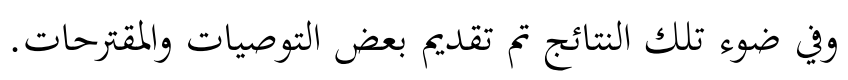
الكلمات المفتاحية: الاختبارات المركزية - التحصيل الدراسي - اللغة العربية - العلوم - الرياضيات. 


\begin{abstract}
This research aims to identify the reasons of declined results of male and female students in the primary and intermediate stages in the achievement tests (Central) in AlBaha region. To achieve this goal, the current research relied on the descriptive analytical approach when describing and analyzing the literature and studies related to the research variables and its tools. Where as a questionnaire was built to determine the reasons for the low results of the primary and middle school students in the achievement tests (central) in Al-Baha region, which consisted of three fields the first is the learner field and the second is field The teacher while the third is the field of the school environment and the descriptive school. The study applied to a sample consisting of (754) male and female teachers, leaders, and supervisors from the employees of education in Al-Baha region were chosen randomly. The research found in its results that there are declined results of male and female students in the primary and intermediate stages in achievement tests (central) in Al-Baha region, as the research indicated the most important reasons for the decline in the learner field which is that the learner's preoccupation with smart devices and programs, the learner's neglect to follow lessons and homework, and the low motivation for the learner about learning. In the field of the teacher the reasons was assigning teaching materials to non-specialists, weak application of continuous evaluation tools for learning among learners, and weak motivation skill. As for the school and descriptive environment, the most important reasons were: weak infrastructure and various facilities for practicing educational activities, lack of activation of math and science laboratories, and insufficient learning methods and techniques in support of teaching in the classroom environment. A proposal was also developed to address the causes of the decline, which included several measures at the school, education office, and education management levels. In light of these results, some recommendations and proposals were presented.
\end{abstract}

Key words: Central tests - Academic achievement - Arabic language - Science Mathematics. 


\section{الفصل الأول \\ مدخل إلى البحث}

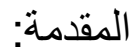

فرضت التغيرات التربوية، والعلمية، والتقنية السريعة على النظم التربوية ومؤسساتا المختلفة أن تنهض

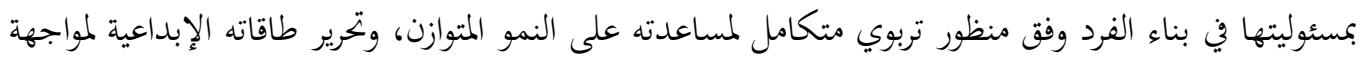

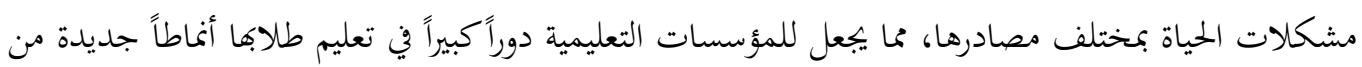
السلوك تستند إلى نماذج عقلية وتربوية، تعمل على رفع مستوى التحصيل الدراسي لديهم. وقد عنيت المملكة العربية السعودية عناية كبيرة بتطوير المنظومة التعليمية؛ لهذا سارعت إلى الأخـذ

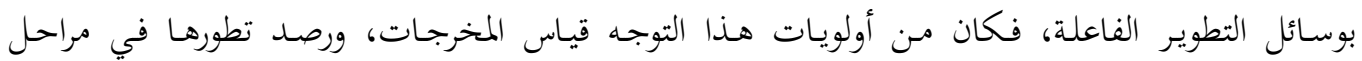

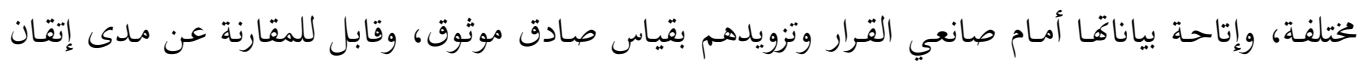

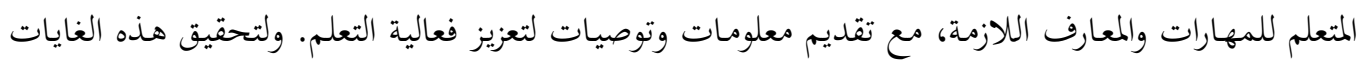

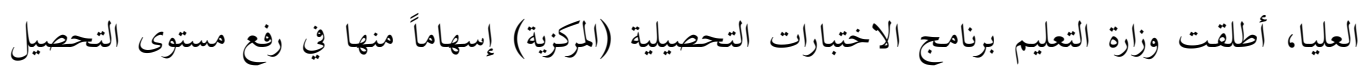

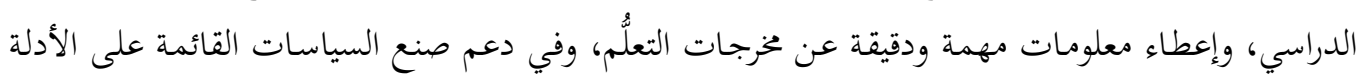
في المملكة العربية السعودية، واختيار السياسات والبرامج التعليمية الناجحة.

ويُعلُّ التحصيل الدراسي هدفًا تربويًا رئيسًا في العملية التعليمية، حيث تشير نتائجه إلى مدى التقدم

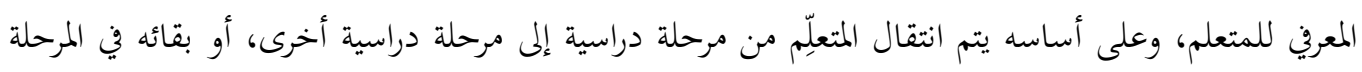

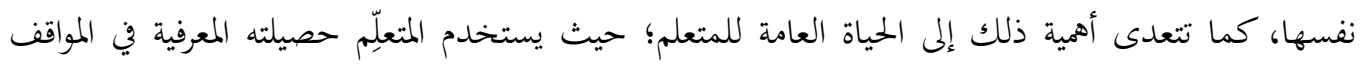

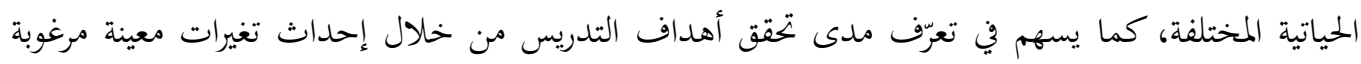

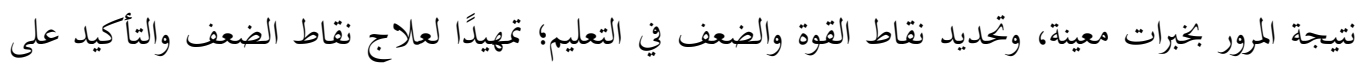
نقاط القوة. (الغامدي، 2016).

وقد سعت وزارة التعليم في المملكة العربية السعودية للوقوف على مدى جودة التحصيل الدراسي حيث

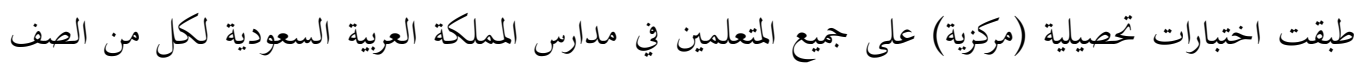

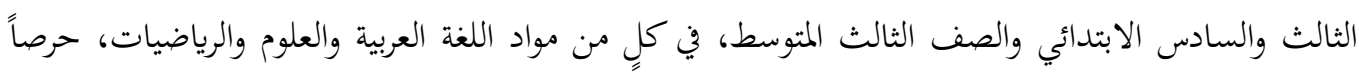
منها على تجويد العملية التعليمية وخاصة فيما يتعلق بنواتج التعلم. 


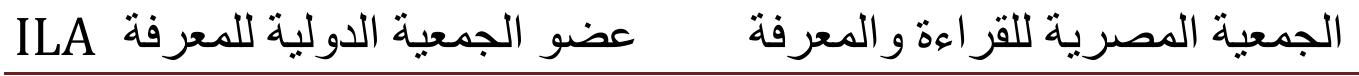

ومن هنا؛ فقد نبعت فكرة هذا البحث لدراسة أسباب تدني نتائج طلاب وطالبات المرحلتين الابتدائية والمتوسطة في الاختبارات التحصيلية (المركزية) بمنطقة الباحة وتقديم توصيات للرفع من مستوى التحصيل الدراسي.

مشكلة البحث:

في ضوء نتائج الاختبارات التحصيلية (المركزية) التي طبقتها وزارة التعليم خلال العام الدراسي 1440/1439هـ والتي أكّدت وجود تدني في نتائج طلاب وطالبات المرحلتين الابتدائية والمتوسطة في الاختبارات المركزية بمنطقة الباحة في المواد المستهدفة وهي اللغة العربية والعلوم والرياضيات كما هو موضح في الجدول التالي:

جدول (1): مقارنة متوسطات إدارة التعليم بمنطقة الباحة مع متوسطات وزارة التعليم

\begin{tabular}{|c|c|c|c|c|c|c|c|}
\hline \multicolumn{3}{|c|}{ الصف الثالث المثوسط } & \multicolumn{3}{|c|}{ الصف السادس الابتدائي } & الثفالث الثف & الصف و المادة \\
\hline 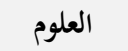 & الرياضيات & 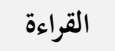 & 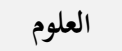 & الرياضيات & 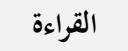 & 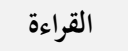 & المتوسطات \\
\hline 227.75 & 187.10 & 245.84 & 239.63 & 189.56 & 264.41 & 223.64 & متوسطات إدارة التعليم \\
\hline 222.89 & 184.75 & 240.22 & 236.17 & 190.73 & 251.34 & 237.56 & متوسطات وزارة التعليم \\
\hline
\end{tabular}

يتضح من الجدول (1) أن هناك مؤشراً يبين انخفاضاً في مستوى التحصيل الدراسي لدى طلاب الصف الثالث الابتدائي في مادة القراءة حيث بلغ المتوسط العام لإدارة التعليم 223,64 وهو مستوى كفاءة منخفض، كما بلغ المتوسط العام للإدارة في مادة القراءة للصف السادس264,41 وهو مستوى كفاءة متوسط، وبلغ متوسط مستوى الكفاءة في مادة الرياضيات لنفس الصف 189,56 وهو مستوى كفاءة منخفض، وفي مادة العلوم بلغ متوسط مستوى الكفاءة 239,63 وهو مستوى كفاءة منخفض، كذلك في منك

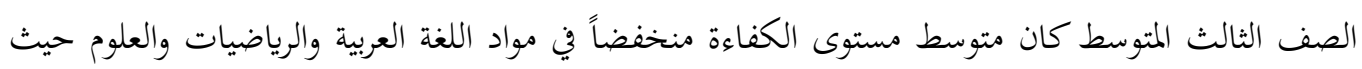
بلغت على التوالي 245,84، 227,75 187,10 


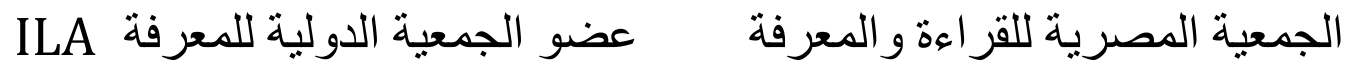

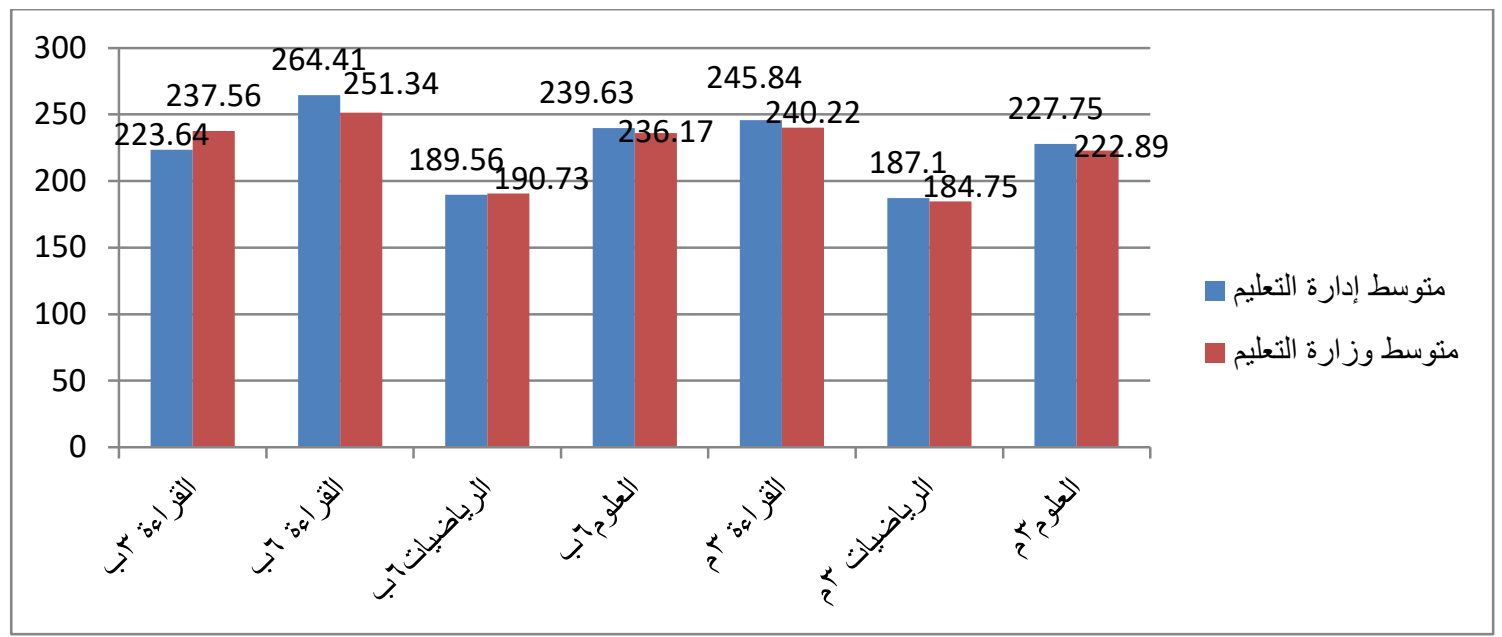

شكل (1): مقارنة متوسطات إدارة التعليم بمنطقة الباحة مع متوسطات وزارة التعليم

وين ضوء ذلك تتحدد مشكلة البحث الحالي في دراسة أسباب تدني نتائج طلاب وطالبات المرحلتين الابتدائية والمتوسطة في الاختبارات التحصيلية بمنطقة الباحة ومعالجتها وتقديم توصيات للرفع من مستوى التحصيل الدراسي. أسئلة البحث: حاول البحث الحالي الإجابة على السؤالين التاليين: 1) ما أسباب تدني نتائج طلاب وطالبات المرحلتين الابتدائية والمتوسطة في الاختبارات التحصيلية (المركزية) من وجهة نظر المعلمين والمعلمات والمشرفين والمشرفات بتعليم منطقة الباحة؟ 2) ما التصور المقترح لمعالجة أسباب تدني نتائج طلاب وطالبات المرحلتين الابتدائية والمتوسطة في الاختبارات التحصيلية (المركزية) بمنطقة الباحة؟

1) تعرّف أسباب تدني نتائج تطبيق الاختبارات التحصيلية (المركزية) من وجهة نظر المعلمين والمعلمات والمشرفين والمشرفات.

2) بناء تصور مقترح لمعالجة أسباب تدين نتائج تطبيق الاختبارات التحصيلية (المركزية). 


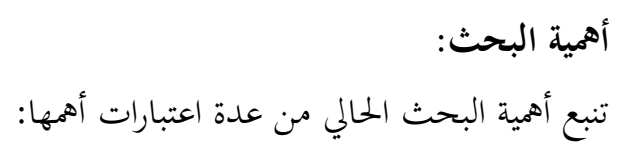

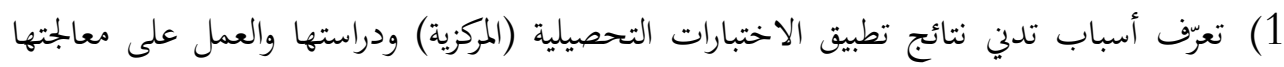
للوصول إلى نتائج جيدة عند تطبيق اختبارات أخرى منائلة.

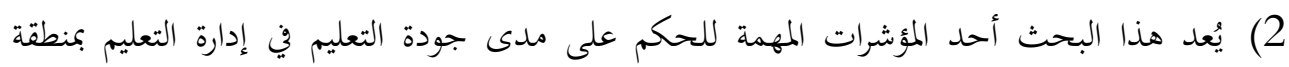
الباحة.

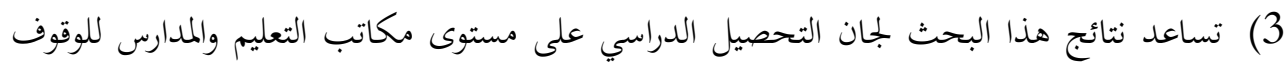

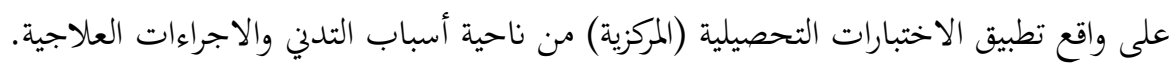

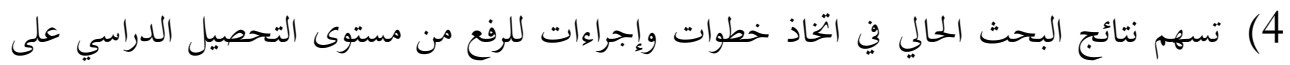
مستوى إدارة التعليم بالمنطقة ومكاتب التعليم والمدارس. 5) يسهم البحث الحالي في إعداد تصور لتهيئة الطلاب والطالبات على الاستعداد للاختبارات الوطنية والدولية كاختبارات التيمز والبيزا والبيرلز.

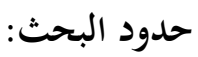

اقتصر البحث الحالي على الحدود التالية: - الموضوعية: الاختبار ات التحصيلية (المركزية) على الصف الثالية التالث الابتدائي في

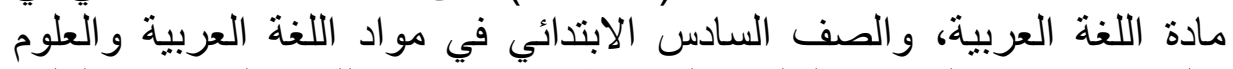

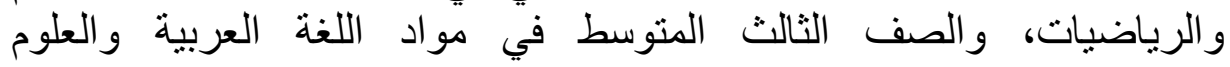

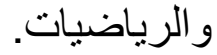
- - البشرية: عينة من معلمي ومعلمات ومشرفي ومشرفات الإدارة العامة للتعليم بمنطقة الباحة. - - المكانية: النطاق الإثر افي للإدارة العامة للتعليم بمنطقة الباحة.

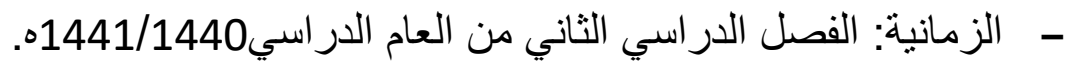

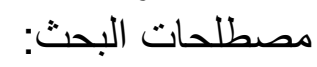
تضمن البحث الحالي الصصطلحات التالية:

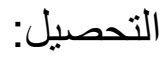

عرفه شحاته و النجار (2003) بأنه: "مقار ما يحصل عليه الطالب من معلومات أو الو بهار

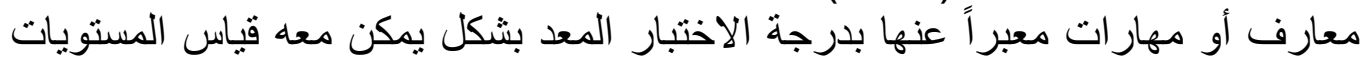
المحدة ويتميز بالصدق و الثبات و الموضو عية" (ص. 89). 


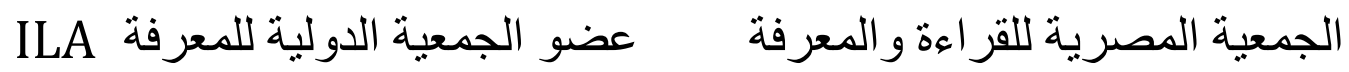

كما عرفه الثايع (2010) بأنه: "استيعاب المعلومات التي اكتسبها الطالب نتيجة

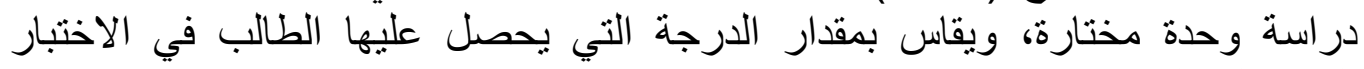

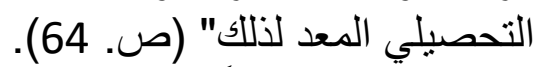

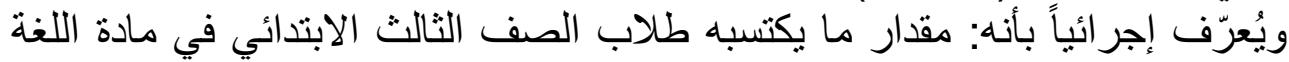

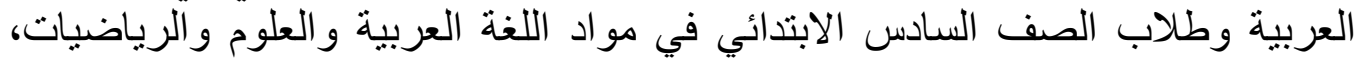

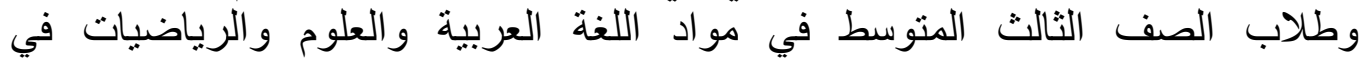

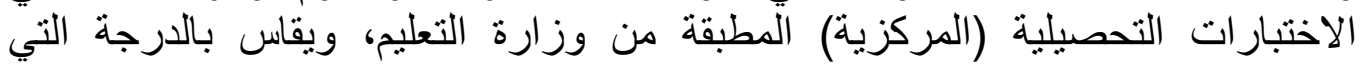

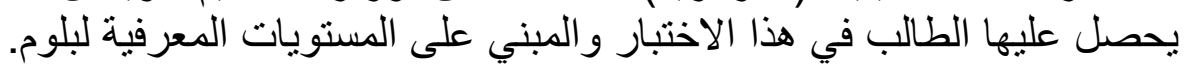
الاختبار ات التحصيلية (المركزية): تعرّف اجرائياً بأها: اختبارات تحصيلية (مركزية) مقننة مبنية على المهارات الأساسية في القراءة والعلوم والرياضيات، تم تحكيمها والتأكد من جودة بنودها وحساب الخصائص السيكومترية لها. 


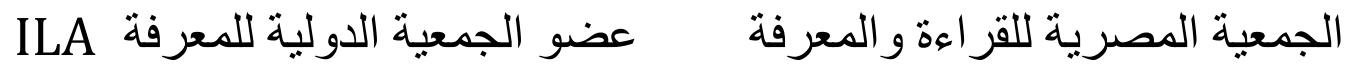

$$
\text { أدبيات البحثل الثاني }
$$

التحصيل الدراسي: - na

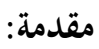

حظي التحصيل الدراسي باهتمام كبير من المتخصصين في ميدان التربية وعلم النفس، لما له من أهمية في

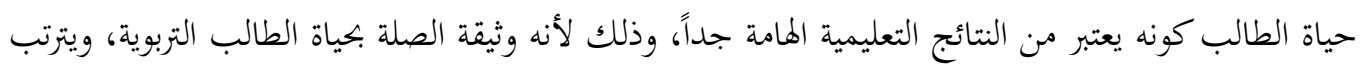

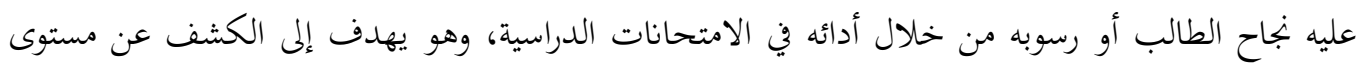

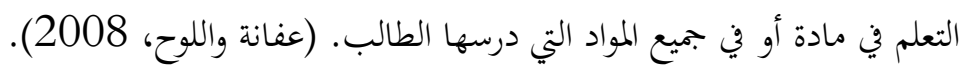

ويؤدي التحصيل الدراسي دوراً كبيراً في تشكيل عملية التعلم وتحديدها، ولكنه ليس المتغير الوحيد في

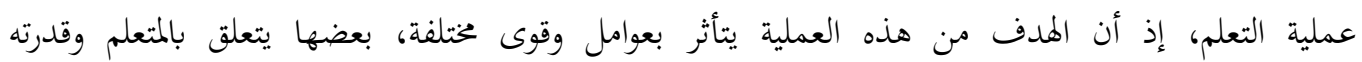
واستعداداته وصفاته المزاجية والصحية، وبعضها متعلق بالخبرة وطريقة تعلمها، وما يحيط بالفرد من إمكانيات. (سناء أبو دقة، 2008).

وبالتالي فإن الدرجات التحصيلية وما ينبثق عنها من تقديرات أساساً مهماً للكثير من الإجراءات

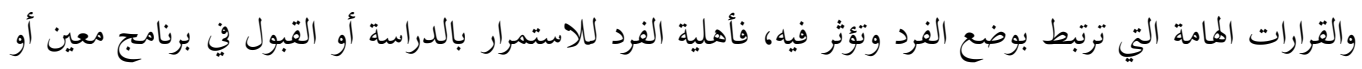

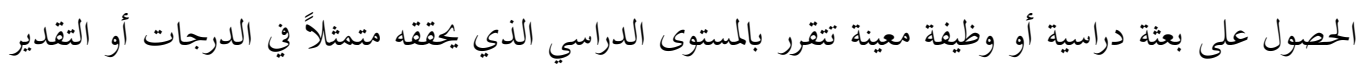
الذي يكصل عليها.

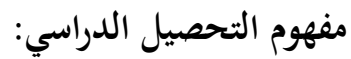

عرف اللقاني والجمل (2003) التحصيل بأنه: "مدى استيعاب الطلاب لما فعلوا من خبرات معينة من

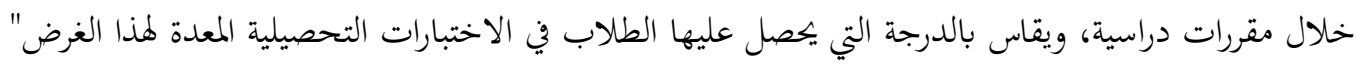

وعرفه حمدان (2008) بأنه: "عملية تركيز الانتباه على موضوع ما وتحصيله، ولاسيما إذا كان مكتوباً أو

$$
\text { مطبوعاً" (ص.37) (37). }
$$

وعرفه سمارة والعديلي (2008) بأنه: "المعلومات والمهارات المكتسبة من قبل المتعلمين كنتيجة لدراسة

$$
\text { موضوع أو وحدة دراسية محددة" (ص. 52). }
$$




\section{ILA الجمعية المصرية للقر اعة والمعرفة عضو الجمعية الدولية للمعرفة}

كما عرفه الشايع (2010) بأنه: "استيعاب المعلومات التي اكتسبها الطالب نتيجة دراسة وحدة مختارة،

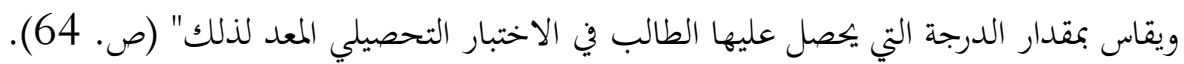

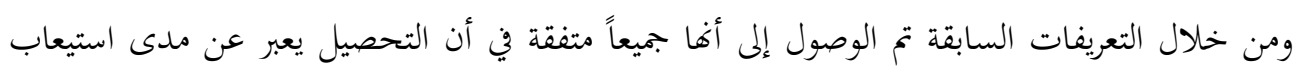
الطالب للمعلومات، أو المعارف، ويقاس بالدرجة التي يكصل عليها الطالب في الاختبار التحصيلي المعد لذلك.

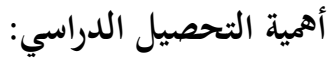

يعد التحصيل الدراسي من الظواهر التي شغلت فكر الكثير من التربويين عامة والمتخصصين بعلم النفس

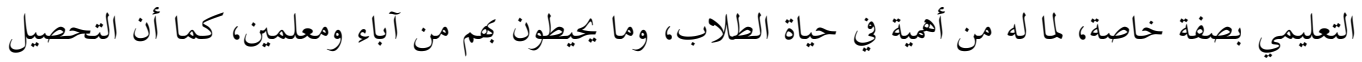

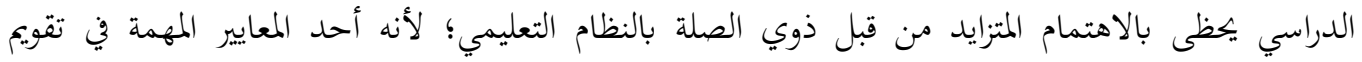

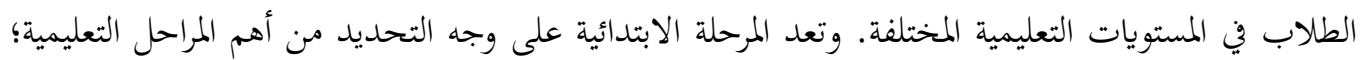

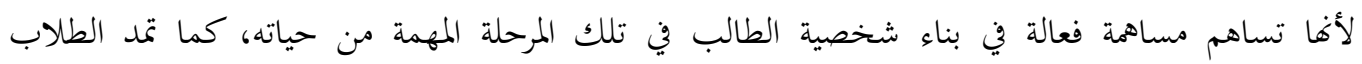
بالأساسيات الضرورية اللازمة لاستمرارهم في المراحل التعليمية التالية. وفي هذا السياق يذكر علي (2002) أن تقويم التحصيل الدراسي ذو أهمية نابعة من كونه يساعد على: 1) توعية الطلاب بمدى تقدمهم نحو الأهداف التعليمية، وزيادة دافعيتهم للتعلم.

2) التخاذ القرار التربوي السليم نحو تصنيف وتوجيه الطلاب إلى نوع معين من التعليم أو تخصص معين. 3) الحكم على فعالية التدريس وتطوير استراتيجياته من خلال نتائج التعلم، وتطوير المناهج الدراسية. حيث أشارت دراسة تيلا (Tell, 2013) إلى أن هناك تأثير كبير بالنسبة لاستراتيجية التعلم بالإقران

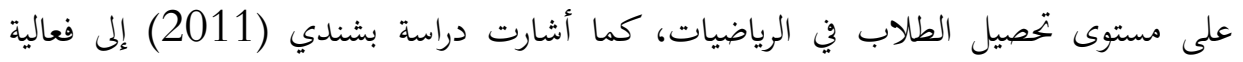
استخدام نموذج التعلم البنائي في تدريس العلوم على مستوى التحصيل المعريف وتنمية بعض المهارات

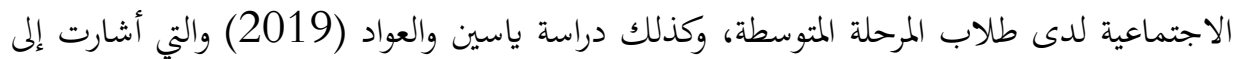
فعالية استخدام استراتيجية ثنائية التحليل والتركيب في تحصيل مادة العروض عند طلاب اللغة العربية. 4) التنبؤ بتحصيل المتعلمين، ومعرفة فرص نجاحهم في مواد دراسية أخرى.

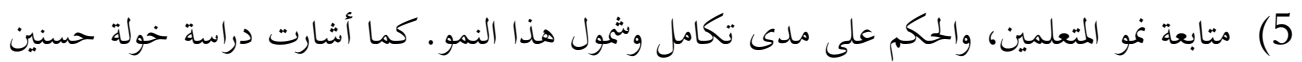

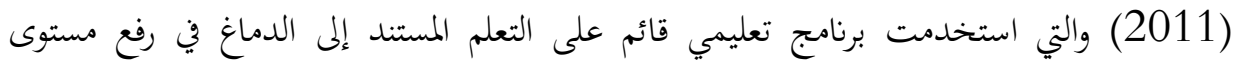




\section{الجمعية المصرية للقر اءة والمعرفة عضو الجمعية الدولية للمعرفة ILA}

التحصيل، وإكساب المفاهيم العلمية، وزيادة الدافعية للتعلم لدى طالبات الصف الرابع الابتدائي في

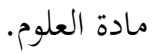

كما يعد تقويم التحصيل عند الطلاب أحد مجالات التقويم المهمة والرئيسية في العملية التعليمية، وقد ذكر الخليلي وحيدر ويونس (2004، 40) أن "تقويم الناحية المعرفية للطلاب - المتمثلة في التحصيل- من أبرز

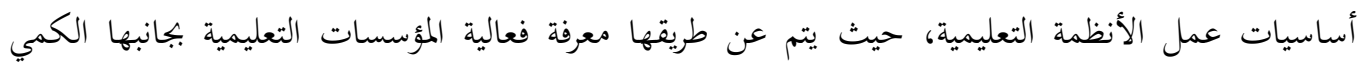

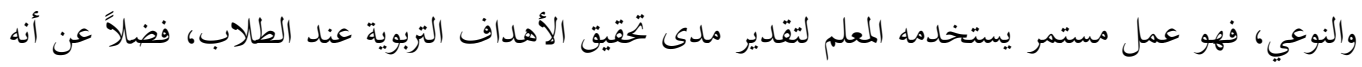

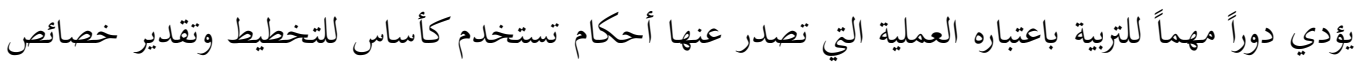
المدرسة من حيث النظام والمناهج وطرق التدريس والنتائج".

ومن خلال ما سبق يمكن القول أن التحصيل يعد من أهم ما يميز الطالب عن غيره من الطلاب، فمن

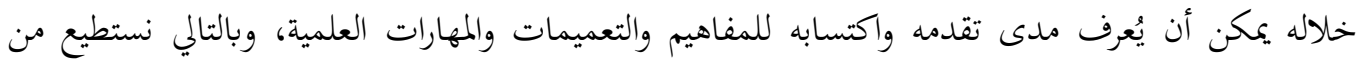

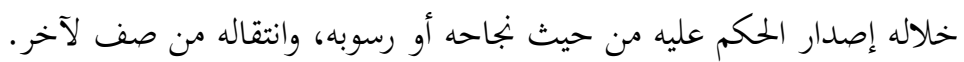

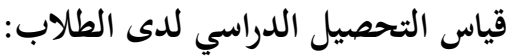

يهتم رجال التربية وغيرهم من المعنيين بالتعليم بالتحصيل الدراسي اهتماماً كبيراً نظراً لأهميته في حياة الفرد

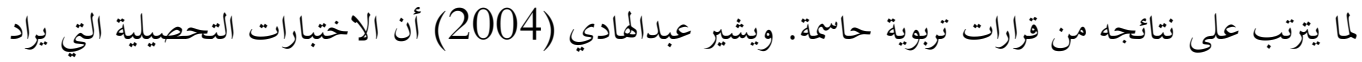

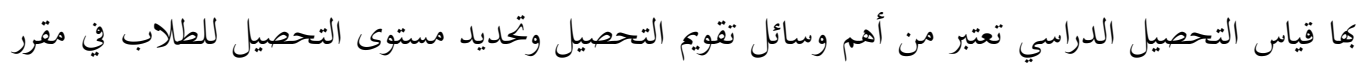

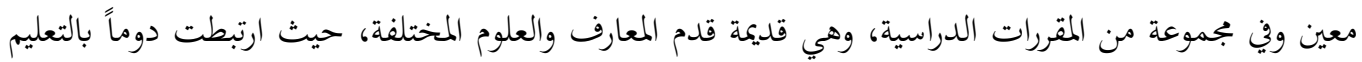
وبمعرفة نتائجه.

كما يذكر أبو علام (2006) أن التحصيل الدراسي يقاس باختبارات تحصيلية يعدها المعلم بنفسه،

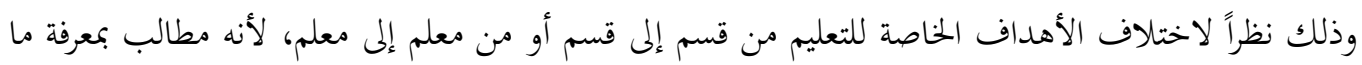
إذا كان طلابه قد تعلموا المفاهيم والخبرات والمهارات التي قدمت لهم في حجرة الدراسة أم لا. لا. وعلى الرغم من تعدد الوسائل المستخدمة في التقويم، إلا أن اختبارات التحصيل تُعُدُ الأكثر شيوعًا بين

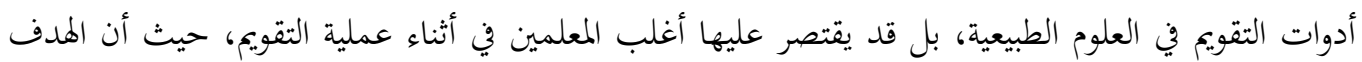

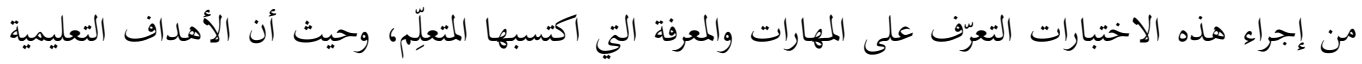
تقسم إلى ثلاثة ججالات: معرفية، ومهارية، ووجدانية، لذا فإن الاختبارات التحصيلية تختص بقياس المجال المعريف 


\section{ILA الجمعية المصرية للقر اءة والمعرفة عضو الجمعية الدولية للمعرفة}

بجميع مستوياته، والتي صنفها بلوم (سعادة وإبراهيم، 2014؛ عبيدات وسهيلة أبو السميد، 2014؛ عطيو،

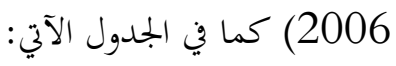

جدول (2): المستويات المعرفية للأهداف حسب تصنيف بلوم

\begin{tabular}{|c|c|c|}
\hline الأفعال الإجرائية & المقصود به & مستوى الهدف \\
\hline 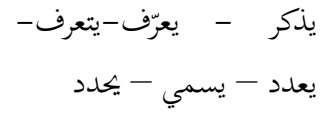 & قدرة المتعلِّم على تذكر واسترجاع المعلومات المكتسبة التي سبق تعلمها، ويمثّل & التذكر \\
\hline يتنبأ يتنج - يعلل - يفسر - & قدفرة المتعلِّم على إدراك معنى المعلومات بطريقة تمكنه من إعادة صياغتها، أو أو إولى إستناجات من خلالها. & الفهم \\
\hline 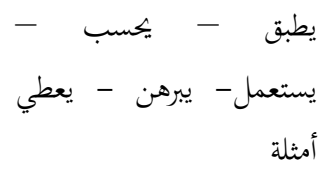 & قدرة المتعلِّم على استخدام المعلومات التي لديه في مواقف جديدة ومحسوسة لم & التطبيق \\
\hline 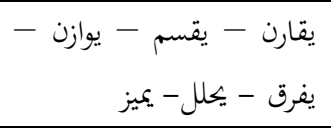 & 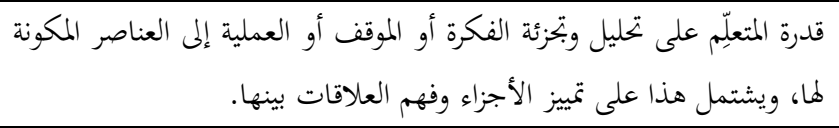 & \\
\hline 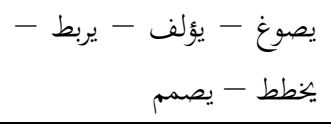 & مدرة المتعلِّم على تنظيم وربط الأجزاء بعضها ببعض؛ لتشكيل كل جديد له & التركيب \\
\hline 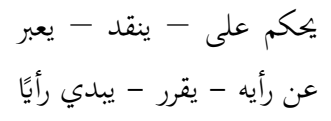 & 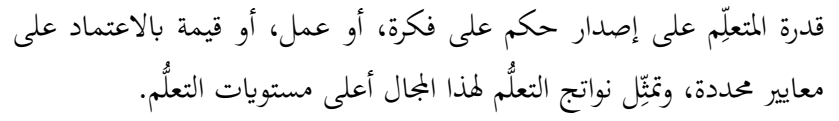 & التقويم \\
\hline
\end{tabular}

العوامل المؤثرة في التحصيل الدراسي: - 20 - n

يتزايد الاهتمام بين المختصين للتعرف على العوامل المؤثرة في التحصيل الدراسي للطلاب، ويأتي هذا الاهتمام من منطلق الكشف عن الطرق التي تساعد على زيادة التفوق الدراسي لتدعيمها وتعزيزها، إضافة إلى لى لئل التعرف على العوامل التي قد تؤدي إلى الإخفاق الدراسي لتجنبها.

ويتداخل عدد من العوامل في التأثير على تحصيل الطالب، وذكر هذه العوامل لا يعني أها السبب الوحيد

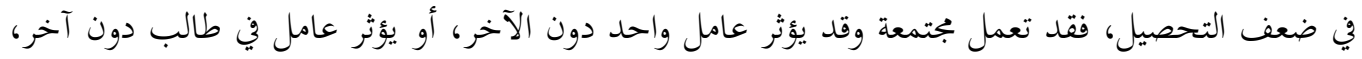

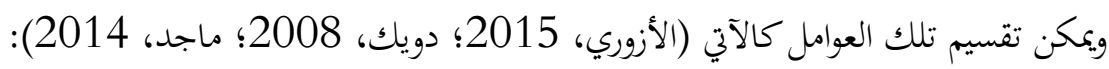




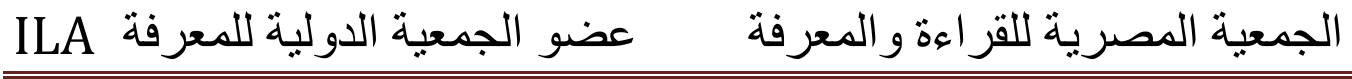

\section{- عوامل عقلية عامة:}

وتشمل التأخر في القدرة على القراءة لعدم الإلمام بأساسياها في وقت مبكر، وأيضاً عدم القدرة على القى

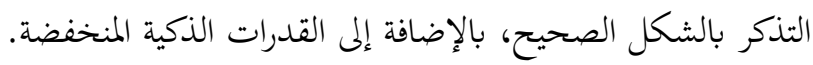

$$
\text { - - عوامل جسمية (صحية) عامة: }
$$

وتشمل ضعف السمع والبصر والهزال والإصابة بالأمراض التي تفقد الجسم حيويته، وبالتالي لا تتيح له الفرصة لبذل الطاقة المطلوبة في عمليتي التعليم والتعلم. - عوامل بيئية تتعلق بالبيئة المدرسية، أو المنزل، أو خارجهما ومن أمثلتها: أ- - انتقال الطالب بين مدارس مختلفة في بيئات مختلفة تبعاً لظروفه الأسرية مما يتبعه تباين بين الطرق التعليمية التي يتلقاها الطالب وعدم إلمامه لبعض أجزاء المنهج الدراسي.

$$
\text { ب- كثرة تغيب الطالب عن المدرسة. }
$$

ج- عدم شعور الطالب بالأمن النفسي داخل المدرسة أو في المنزل.

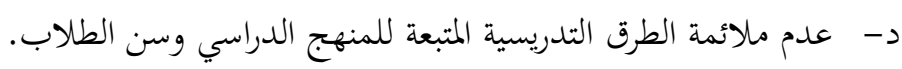
هـ - علاقة الطالب بوالديه ومعلميه وزملائه بالمدرسة.

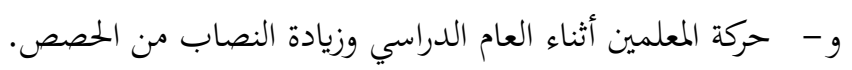

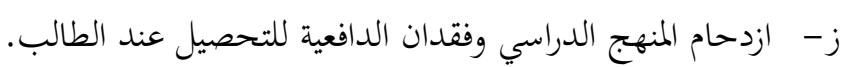

$$
\text { ح- المستوى الاقتصادي والتعليمي للأسرة. }
$$

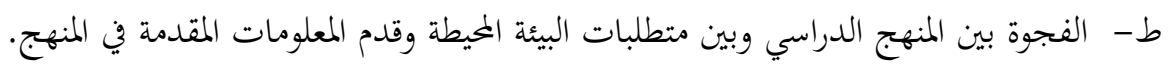

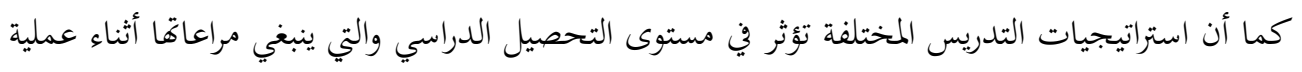

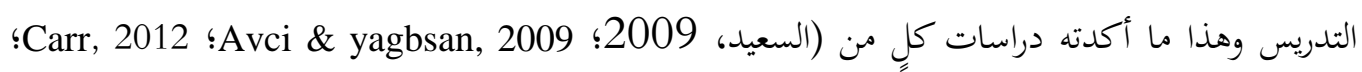

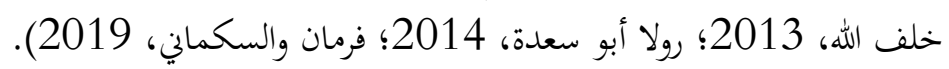
كما يرى (بسماء آدم، 2004؛ نُمَّ، 2004؛ دمنهوري،

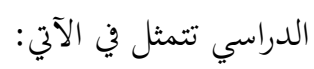




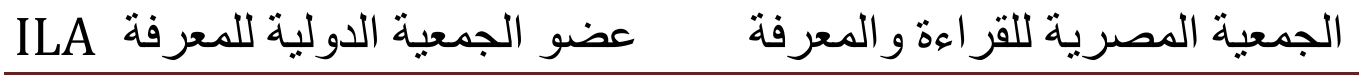

أولًا : العوامل الموضوعية والخارجية:

1) طريقة التدريس الكلية والجزئية: اختلف العلماء في إحدى الطريقتين على الأخرى ، ولكن من الموريه

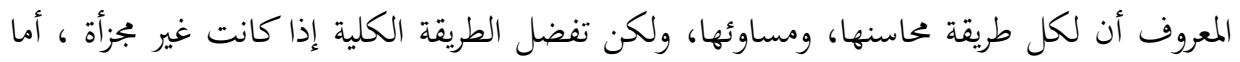
الطريقة الجزئية فيفضل استخدامها في حالة تعدد أجزاء المادة أو صعوبتها.

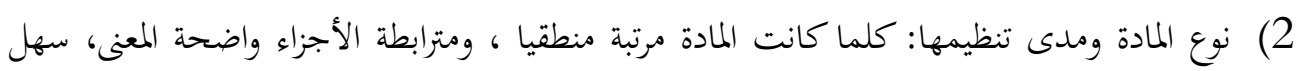
حفظها ومراجعتها. التسميع الذاتي: وهي محاولة استرجاع المعلومات أثناء الحفظ مما يساعد على تثبيت المعلومات والقدرة

$$
\text { على استدعائها. }
$$

4) التوجيه والإرشاد: ثبت أن التحصيل الذي يقترن بالإرشاد والتوجيه أفضل من التحصيل بدوغما حيث أن المتعلم يعي أهمية المراد تحصيله.

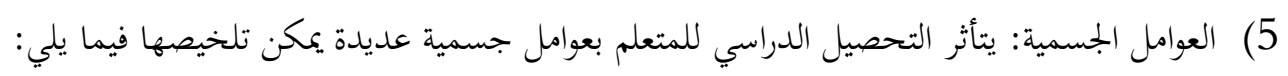

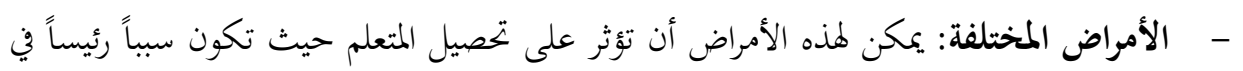

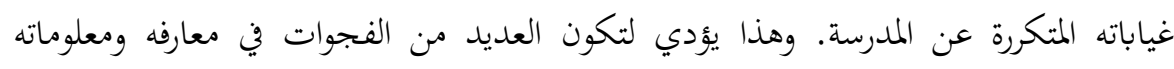

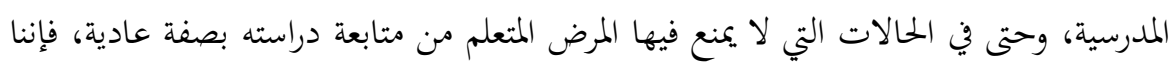

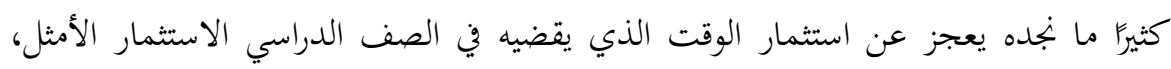

$$
\text { وذلك بسبب عجزه عن التركيز في البعض أو الكثير من الأحيان. }
$$

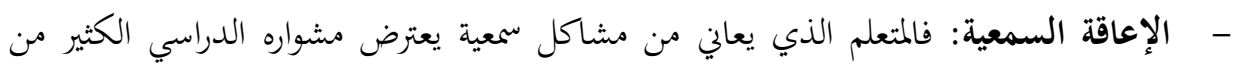

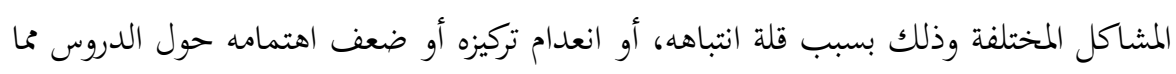

$$
\text { يؤدي إلى تدني التحصيل الدراسي. }
$$

- - الإعاقة البصرية: اكتشاف هذه الإعاقة بالنسبة للمعلم أسهل من اكتشاف الإعاقة السمعية،

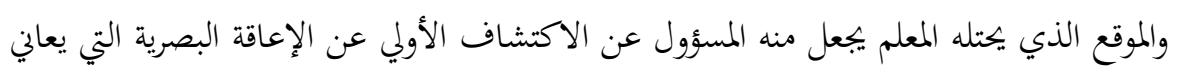

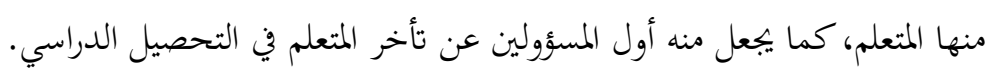

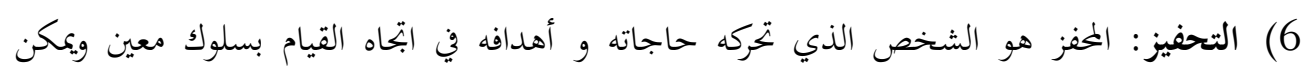

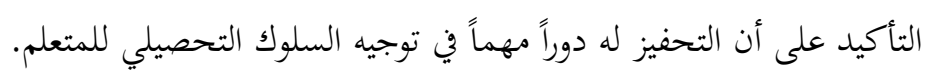

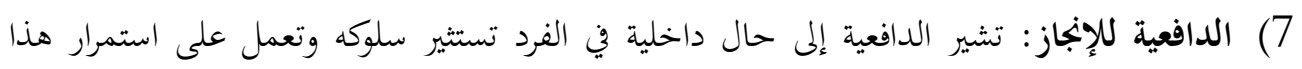

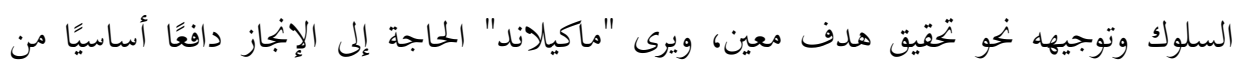




\section{ILA الجمعية المصرية للقر اعة والمعرفة عضو الجمعية الدولية للمعرفة}

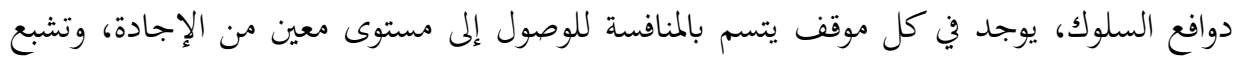

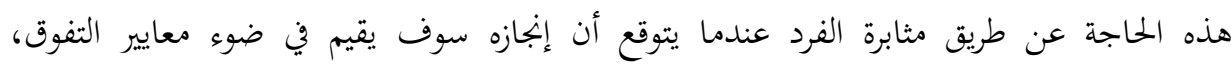

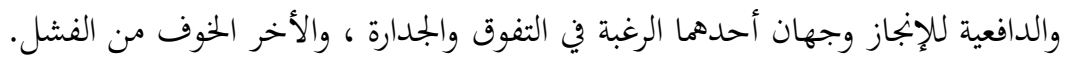

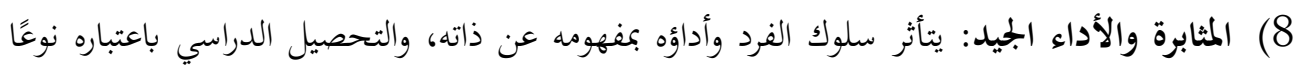

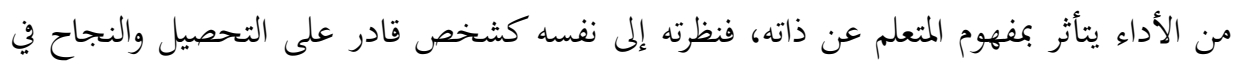
تعلمه المدرسي، تعمل كقوة منشطة تدفعه إلى تأكيد هذه النظرة والحفاظ عليها.

ثانيًا: العوامل الذاتية والداخلية:

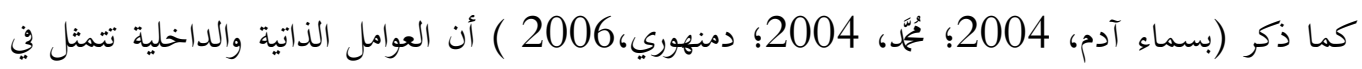

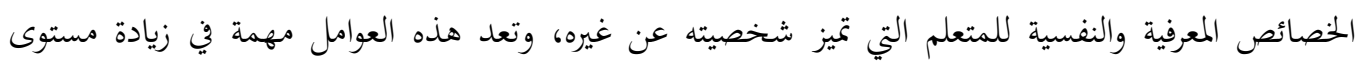
التحصيل عند المتعلم ومن هذه الخصائص ما يلي:

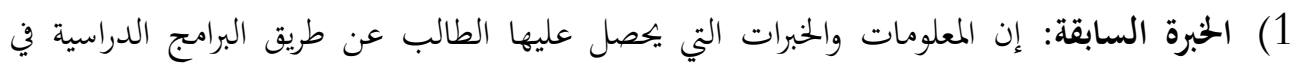

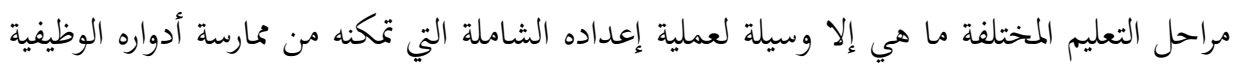

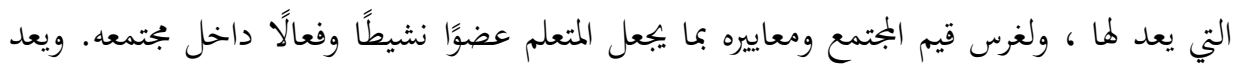

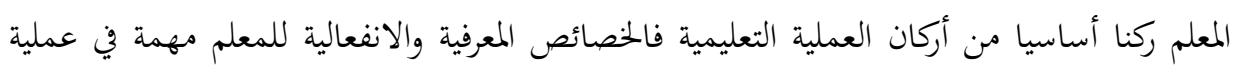

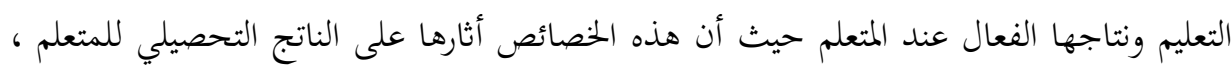

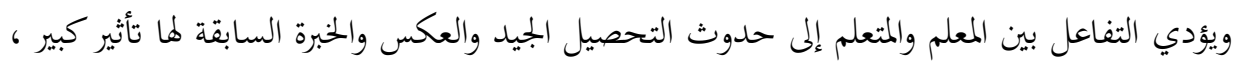
فإلمام التلميذ باللغة الإنجليزية من الممكن أن يعينه في تعلم اللغة الفرنسية.

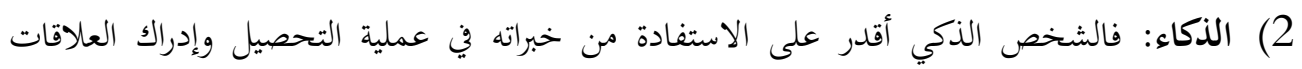

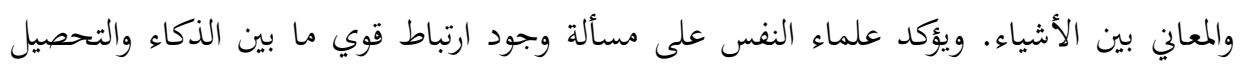

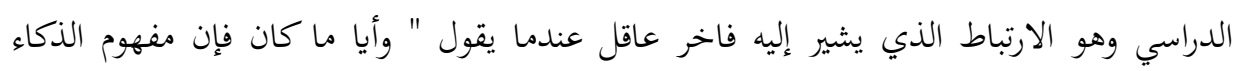
يتصل اتصالاً وثيقًا بالقدرة على التعلم. 3) الشخصية: وهي عبارة عن التراكيب والعمليات السيكولوجية الثابتة التي تنظم الخبرة الإنسانية

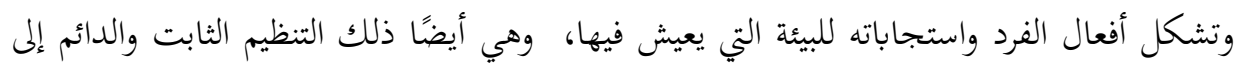

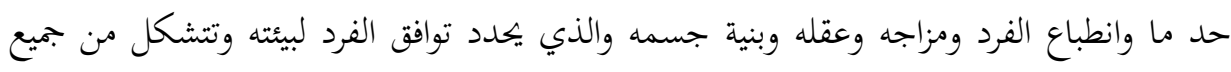

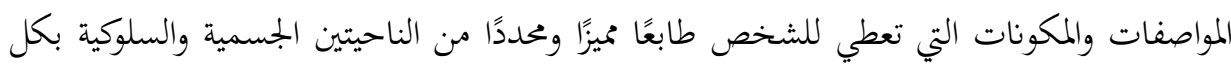

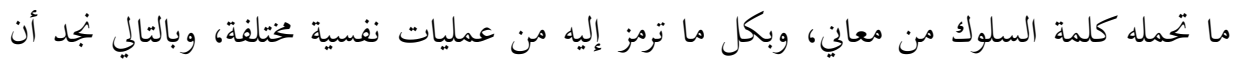




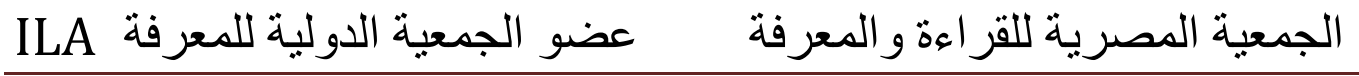

دافعية المتعلمين للإنجاز تتعلق بخصائص شخصيتهم وقدراقم العقلية، ومن الخصائص الشخصية المهمة: - - الثقة بالنفس والثبات الانفعالي وامتلاك ابتحاتات إيجابية نخو التعلم والتفاعل الشخصي الجيد مع نشاطات المدرسة. - اتخاذ القرارات والأساليب المعرفية والعقلية التي تتمثل في المرونة الفكرية والاستدلال بشقيه الاستقرائي والاستباطي، والقدرة على مواجهة المشكلات.

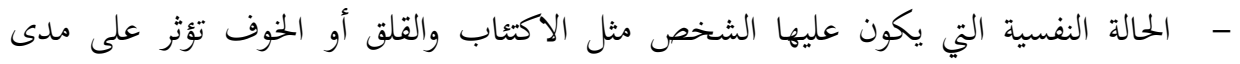
تحصيله الدراسي.

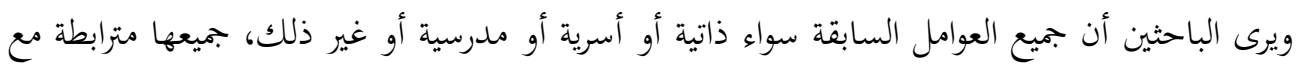
بعضها البعض وكل واحدة تؤثر على الأخرى، ولها دور كبير في التأثير على التحصيل الدراسي، ويتوقف نجاح

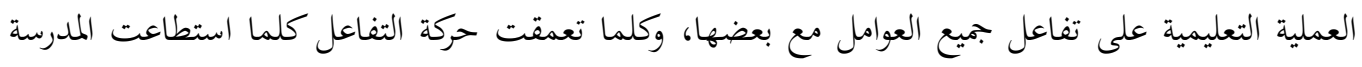
تحقيق ما تصبو إليه من خلق جيل واع، متسلح بسلاح العلم والمعرفة، ملتزم بالأخلاق الإنسانية العليا.

\section{الاختبارات المركزية:}

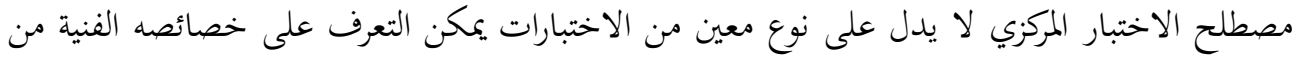

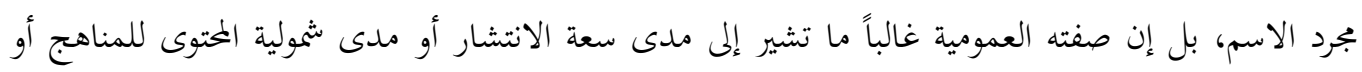
المقرر أو مدى مركزية ولا مركزية الإدارة.

وتعرّف الاختبار ات التحصيلية (المركزية): بأنها: اختبار ات تحصيلية (مركزية)

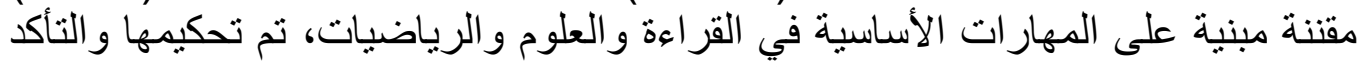

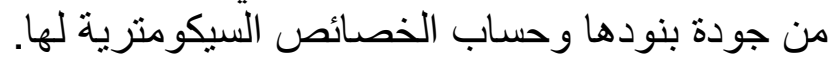

$$
\text { أهداف الاختبارات المركزية: - من جوده }
$$

$$
\text { تحدف الاختبارات المركزية لمجموعة من الأهداف يمكن تلخيصها فيما يلي: }
$$

1) تقديم مؤشرات علمية وموضوعية عن مستويات الطلبة للحكم على جودة التعليم في المملكة. 2) تقديم تغذية راجعة للمدارس ومكاتب وإدارات التعليم وقطاعات الوزارة عن نواتج تعلم الطلبة.

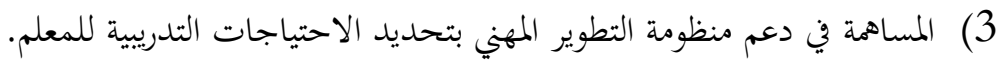




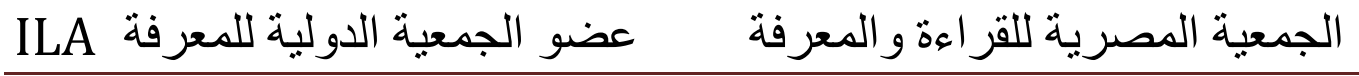

4) توفير بيانات عن مستوى أداء الطلبة تفيد في متابعة نمو مستوى أدائهم الدراسي.

\section{أهمية الاختبارات المركزية:}

$$
\text { تعود أهمية الاختبارات المركزية إلى دوره فيما يلي: }
$$

- - توفير مؤشرات حقيقية توضح مقدار التقدم الذي أحرزه المتعلم قياساً بالأهداف التعليمية المرصودة

$$
\text { على نحو مسبق. }
$$

- - مساعدة المعلم على إصدار أحكام موضوعية على مدى فعالية أساليب التدريس التي استخدمها في

تنظيم العملية التعليمية التعلمية.

- - تحديد الجوانب الإيجابية في أداء المتعلم والعمل على تعزيزها، فضلاً عن تشخيص جوانب الضعف في الفيه

تحصيل الطلبة، تمهيداً لبناء الخطط العلاجية.

- - استثارة دافعة الطلبة للتعلم، وحثهم على تركيز الانتباه في الخببرات التعليمية المقدمة، والاستمرار في

$$
\text { النشاط والاندماج في هذه الخبرات لتحقيق أهداف التعلم. }
$$

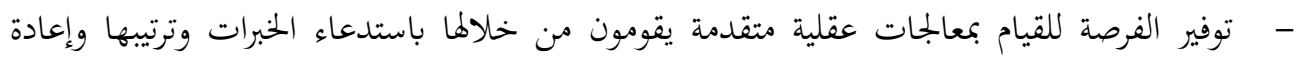

$$
\text { تنظيمها لتلاءم المواقف التي تفرضها المواقف الاختبارية. }
$$

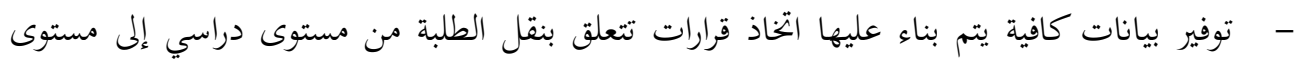
أعلى.

وقد وُجهت إلى الاختبارات المركزية انتقادات من حيث الأسس والإجراءات والنتائج السلبية التي تنتج عنها، إلا أهما تكتسب أهميتها من اعتبارات متعددة منها:

1) مركزية الإدارة، حيث يكون الإشراف المباشر على وضع الأسئلة وإدارة الاختبار، وتصحيح

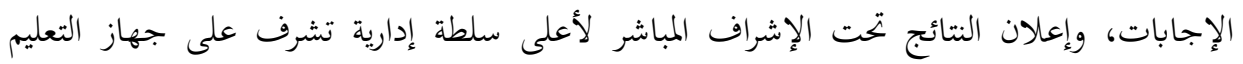

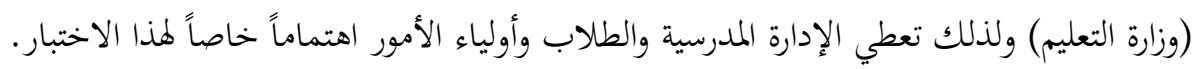
2) العادات والأعراف والقيم الاجتماعية المرتبطة بنتائج هذا الاختبار، حيث يتم الاعلان عن النتائج

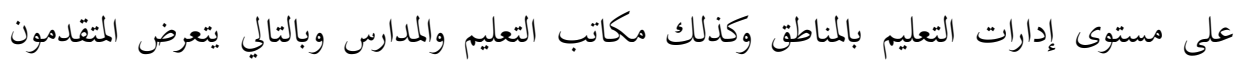
للاختبار إلى تصنيفات مختلفة. 


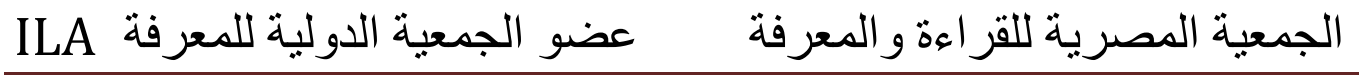

3) الاستخدام الذي توضع فيه النتائج، حيث تستخدم نتائج الاختبار لاتخاذ قرارات هامة تؤخذ بناءً على نتائج هذه الاختبارات.

$$
\text { ويتم التركيز في الوضع المدرسي على (التحصيل) وذلك لأسباب منها: }
$$

- - سهولة بناء أدوات القياس (بالمقارنة مع المجالات الأخرى) وذلك لأن التحصيل يرتبط بشكل مباشر

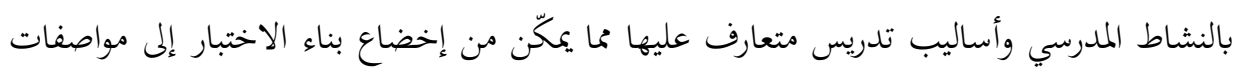
ومعايير مقبولة ومتفق عليها مثل صدق المحتوى. - شيوع الخببرة اللازمة لبناء الاختبار بين عدد كبير نسبياً من التربويين في المجال التعليمي بسبب الخبرة والممارسة . - سهولة اختيار المعايير وتفسير النتائج سواءً كانت المعايير المختارة نسبية أو محكية أو غير ذلك. - - تعود المتعلمين والمعلمين على الأنماط السائدة في هذا النوع من الاختبارات مما يجعله مألوفاً ومقبولاً. كما أن هذه الممارسات تضغط على نظام التعليم باتجاه التركيز على التحصيل أو بعض عناصره وفي

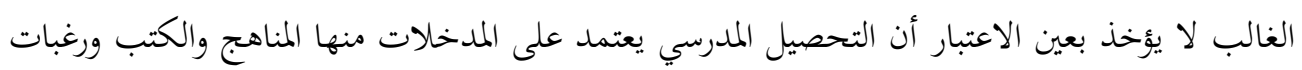

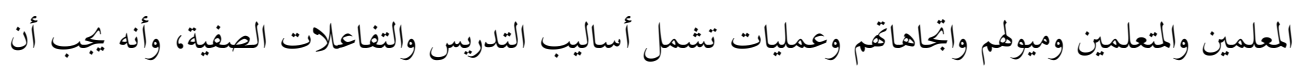
تخضع هذه المدخلات والعمليات إلى التقييم أيضاً وأن تفسر نتائج الأفراد بدلالتها. لذلك فإن أي نظام تعليمي متكامل لابد أن يتناول هذه العناصر (مدخلات، عمليات، مخرجات) بشكلٍ متكامل في التقييم، وهذا لا يعني بالضرورة أن تكون هذه الجوانب المختلفة موضوعاً للتقييم اليومي

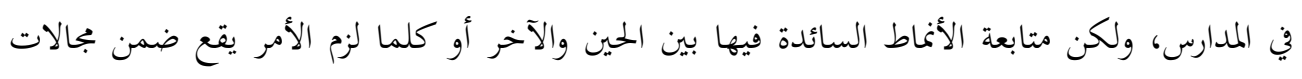
الاهتمام من أجل إعطاء المعنى المناسب لنتائج الاختبارات المدرسية بشكلٍ عام والاختبارات المركزية بشكل خاص. 


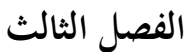

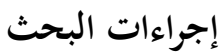

تناول هذا الفصل الإجراءات التي اتبعت للإجابة عن تساؤلات البحث، من حيث تحديد منهج وعينة

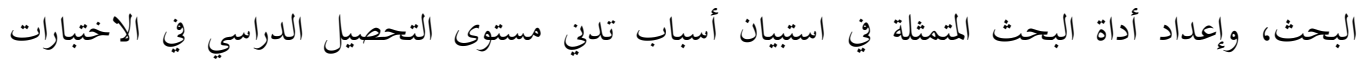
التحصيلية (المركزية) لدى بعض الطلاب والطالبات بمنطقة الباحة من وجهة نظر المعلمين والمعلمات وقادة

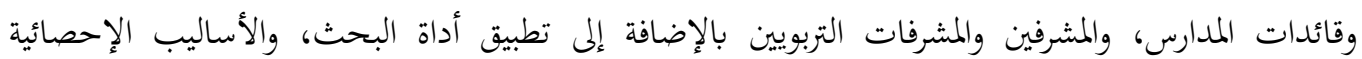

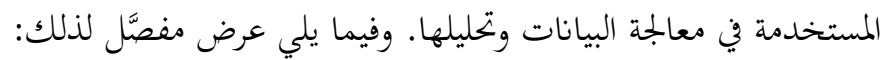

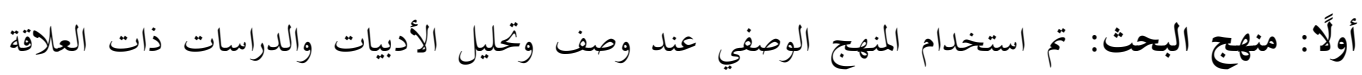

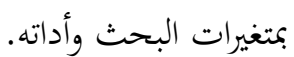
ثانيًا: مجتمع البحث: تكوَّن مجتمع البحث الحالي منسوبي إدارة التعليم بمنطقة الباحة التعليمية من المعلمين والمعلمات وقادة وقائدات المدارس، والمشرفين والمشرفات التربويين.

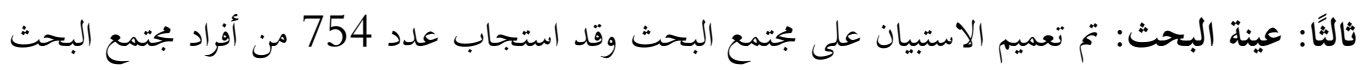

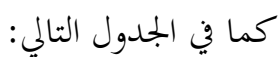

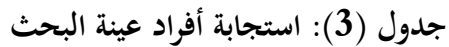

\begin{tabular}{|c|c|c|c|c|}
\hline مشرفين ومشرفات & قادة وقائدات & مرشدين ومرشدات & معلمين ومعلمات & أفراد العينة \\
\hline 67 & 227 & 82 & 387 & العدد \\
\hline \multicolumn{4}{|c|}{754} & الجموع \\
\hline
\end{tabular}

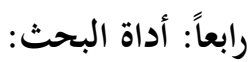

استبانة أسباب تدني نتائج طلاب وطاهبات المرحلتين الابتدائية والمتوسطة في الاختبارات التحصيلية (المركية)

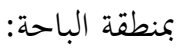

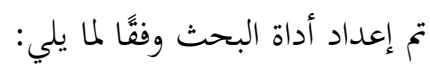
- متديد المدف من الاستبانة: حيث هدفت إلى تعرف أسباب تدني نتائج طلاب وطالبات المرحلتين الابتدائية والمتوسطة في الاختبارات التحصيلية (المركزية) بمنطقة الباحة من وجهة نظر المعلمين والمعلمات وقادة وقائدات المدارس، والمشرفين والمشرفات التربويين. 
- تزويد الاستبانة بمقدمة تعرّف المفحوصين بطبيعة الاستبانة، وتوضح لم طريقة الإجابة على فقراتما من خلال مثال توضيحي. - - محديد فقرات الاستبانة حسب بمالاتا، ودرجة الممارسة وذلك وفقاً لمقياس ليكرت الخماسي.

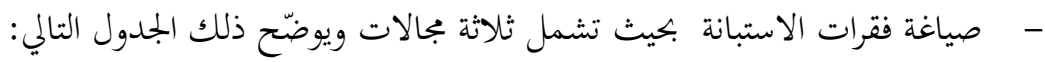
جدول (4): مواصفات فقرات الاستبانة

\begin{tabular}{|c|c|c|c|}
\hline الوزن النسبي & إجمالي عدد الفقرات & 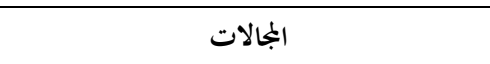 & م \\
\hline$\% 35$ & 15 & العوامل المتعلقة بالمتعلم & 1 \\
\hline$\% 37$ & 16 & العوامل المتعلقة بالمعلم & 2 \\
\hline$\% 28$ & 12 & العوامل المتعلقة بالبيئة المدرسية والصفية & 3 \\
\hline$\% 100$ & 43 & المجموع & \\
\hline
\end{tabular}

طريقة تقدير الدرجات لفقرات الاستبانة: - م

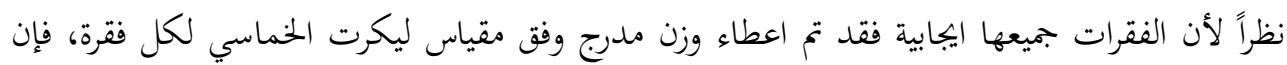

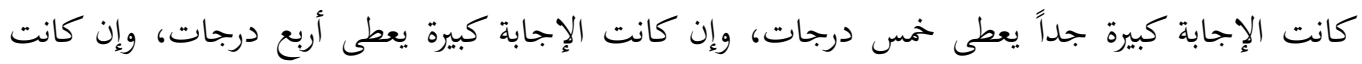

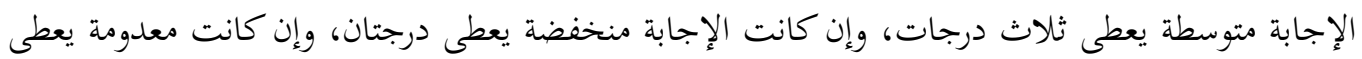
درجة واحدة فقط. ضبط الاستبانة، حيث تم القيام بالتالي: أ) عرض الاستبانة على بجموعة من المتخصصين لضبطها موضوعيا في ضوء صحة ودقة الصياغة اللغوية

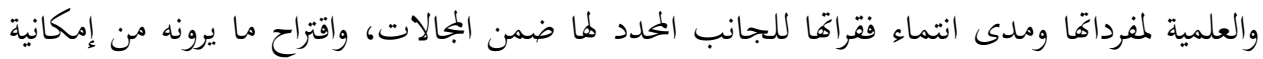

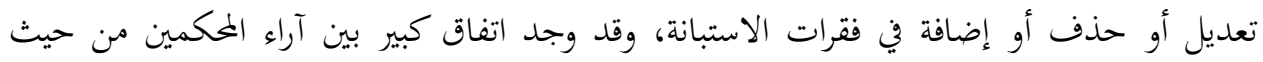

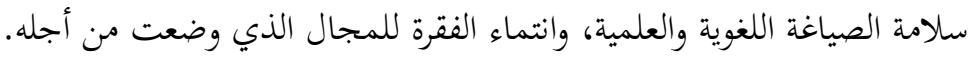

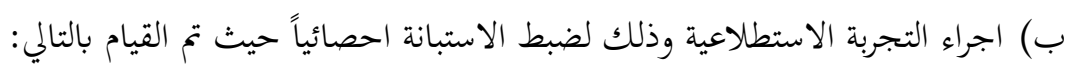

أولًا : صدق الاتساق الداخلي للأداة (Internal Consistency): مع التحقق من توفر مؤشر الصدق الظاهري للاستبانة تم تطبيقها على عينه استطلاعية من معلمين

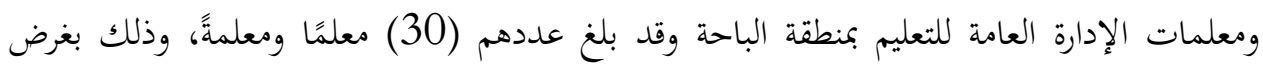




\section{الجمعية المصرية للقر اعة والمعرفة عضو الجمعية الدولية للمعرفة ILA}

الإفادة من بيانات هذا التطبيق في استخلاص معايير صدق البناء الداخلي وهذا ما أمكن اجراؤه على :

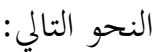

جدول (5): معاملات الارتباط بين درجات كل عبارة من عبارات الخور الأول بالدرجة الكلية للمحور نفسه

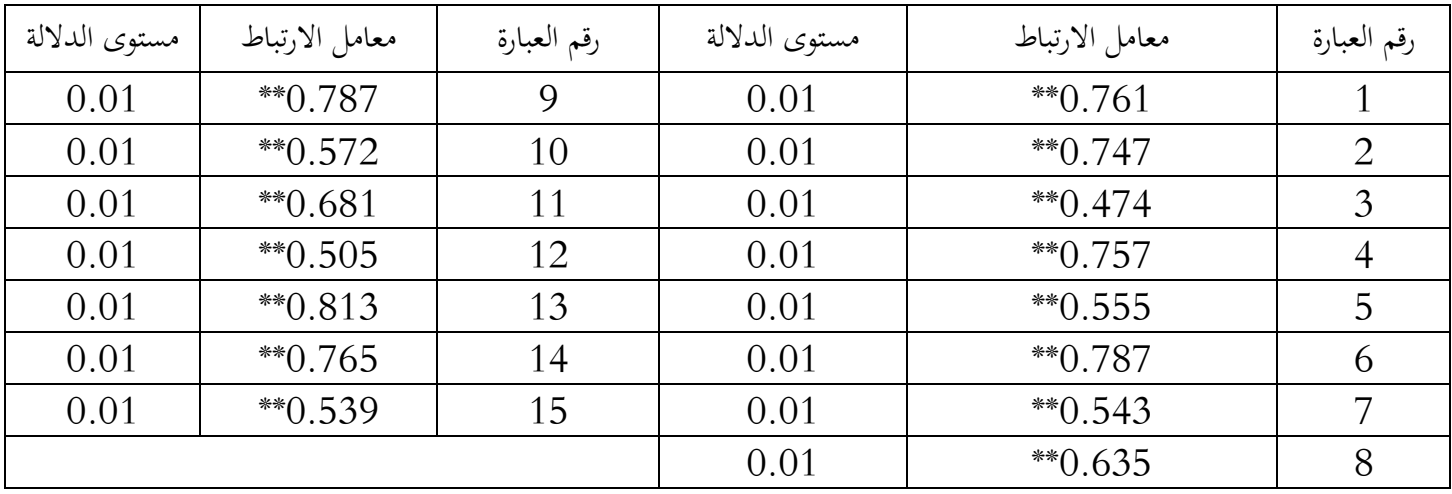

جدول (6): معاملات الارتباط بين درجات كل عبارة من عبارات الخور الثاني بالدرجة الكلية للمحور نفسه

\begin{tabular}{|c|c|c|c|c|c|}
\hline مستوى الدلالة & معامل الارتباط & رقم العبارة & مستوى الدلالة & معامل الارتباط & رقم العبارة \\
\hline 0.01 & *** 0.852 & 9 & 0.01 & *** 0.492 & 1 \\
\hline 0.01 & *** 0.824 & 10 & 0.01 & *** 0.512 & 2 \\
\hline 0.01 & **0.712 & 11 & 0.01 & **0.557 & 3 \\
\hline 0.01 & $* * 0.719$ & 12 & 0.01 & ***0.714 & 4 \\
\hline 0.01 & **0.538 & 13 & 0.01 & **0.864 & 5 \\
\hline 0.01 & $* * 0.786$ & 14 & 0.01 & *** 0.868 & 6 \\
\hline 0.01 & *** 0.884 & 15 & 0.01 & ***0.848 & 7 \\
\hline 0.01 & *** 0.747 & 16 & 0.01 & ***0.777 & 8 \\
\hline
\end{tabular}

جدول (7): معاملات الارتباط بين درجات كل عبارة من عبارات الخور الثالث بالدرجة الكلية للمحور نفسه

\begin{tabular}{|c|c|c|c|c|c|}
\hline مستوى الدلالة & معامل الارتباط & رقم العبارة & مستوى الدلالة & معامل الارتباط & رقم العبارة \\
\hline 0.01 & *** 0.842 & 7 & 0.01 & ***0.754 & 1 \\
\hline 0.01 & $* * 0.716$ & 8 & 0.01 & ***0.857 & 2 \\
\hline 0.01 & **0.588 & 9 & 0.01 & $* * 0.653$ & 3 \\
\hline 0.01 & **0.876 & 10 & 0.01 & $* * 0.631$ & 4 \\
\hline 0.01 & ***0.588 & 11 & 0.01 & $* * 0.721$ & 5 \\
\hline 0.01 & ${ }^{* * *} 0.675$ & 12 & 0.01 & **0.882 & 6 \\
\hline
\end{tabular}




\section{الجمعية المصرية للقر اءة والمعرفة عضو الجمعية الدولية للمعرفة ILA}

تُظهر نتائج الجداول أعلاه (7,6,5) أن جميع العبارات ترتبط بمحاورها التي تم تصنيفها إليها بدلالة إحصائية عند مستوى (0,01) وقد تراوحت معاملات الارتباط بين العبارات والدرجة الكلية للمحور الاول

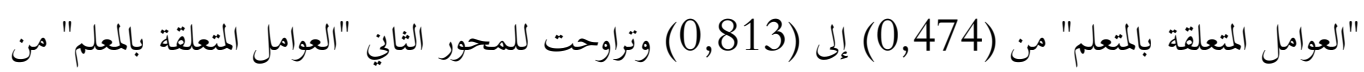

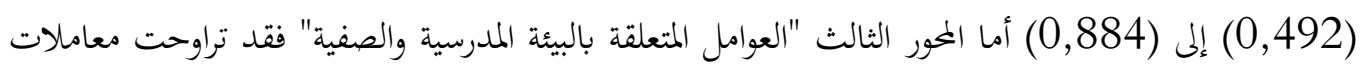

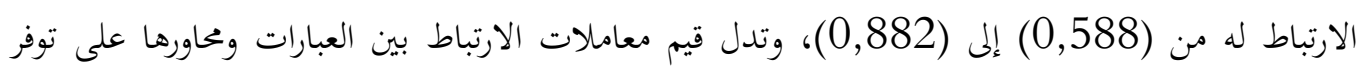
الاتساق بين استجابات العينة على تلك العبارات بمحاورها التي تم تصنيفها فيها. جدول (8): معامل الارتباط بين درجة كل محور من محاور الاستبانة والدرجة الكلية لها

\begin{tabular}{|c|c|c|}
\hline مستوى الدلالة & معامل الارتباط & الخور \\
\hline 0.01 & ***853 & العوامل المتعلقة بالمتعلم \\
\hline 0.01 & *** 0.748 & العوامل المتعلقة بالمعلم \\
\hline 0.05 & ${ }^{*} 0.432$ & العوامل المتعلقة بالبيئة المددرسية والصفية \\
\hline
\end{tabular}

يتضح من نتائج الجدول رقم (8) أنّ معاملات الارتباط بين الدرجة الكلية لأداة البحث (الاستبانة)

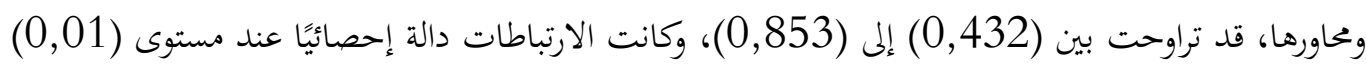

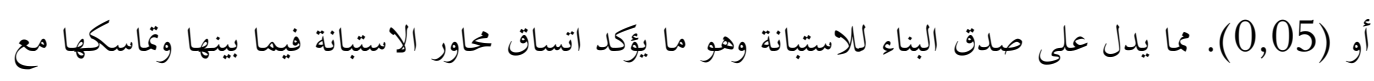
بعضهما البعض. 
ثانيًا: ثبات الاستبانة (Reliability)

للتحقق من ثبات الاستبانة استخدمت معادلة الفاكرونباخ للثبات - وهي اقوى معاملات الثبات كما

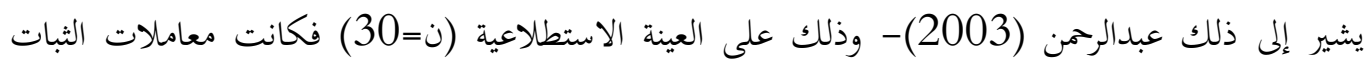
للمحاور والدرجة الكلية للاستبانة على النحو التالي:

جدول (9): قيم معامل ألفاكرونباخ لأداة البحث

\begin{tabular}{|c|c|c|}
\hline معامل ثبات ألفا & عدد الفقرات & محاور الاستبانة \\
\hline 0.909 & 15 & العوامل المتعلقة بالمتعلم \\
\hline 0.940 & 16 & العوامل المتعلقة بالمعلم \\
\hline 0.922 & 12 & العوامل المتعلقة بالبيئة المدرسية والصفية \\
\hline 0.923 & 43 & الثبات العام لأداة البحث \\
\hline
\end{tabular}

يتضح من الجدول رقم (9) أن قيم معاملات الثبات على نطاق محاور أداة البحث تراوحت ما بين

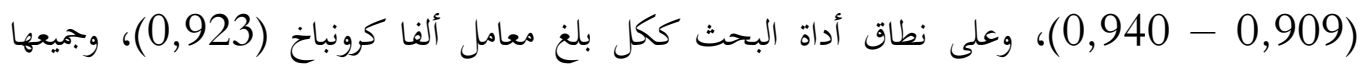

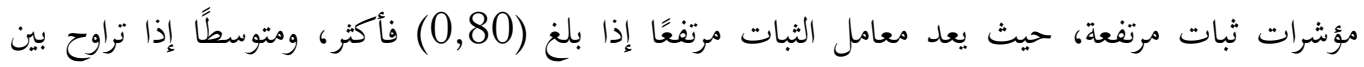

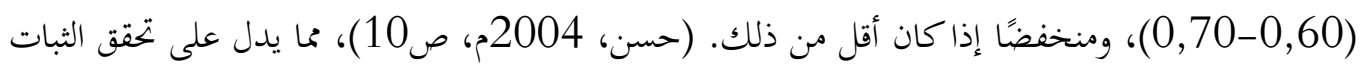

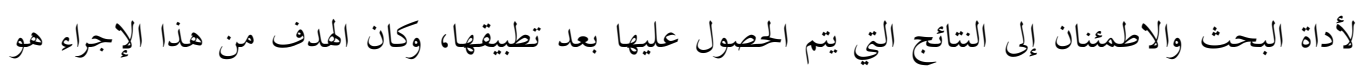

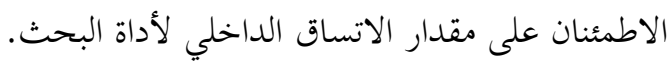

\section{الوصف الإحصائي لمفردات عينة البحث:}

تتسم مفردات عينة البحث بعدد من الخصائص في ضوء متغيرات البحث الديموغرافية المتمثلة في: (العمل

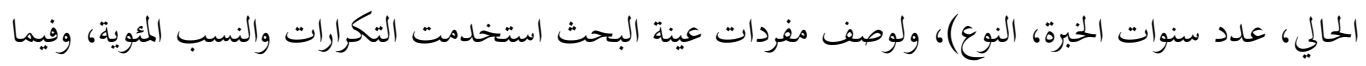

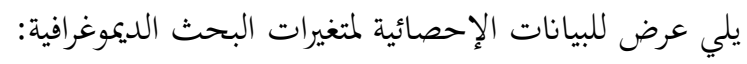


جدول (10): وصف خصائص مفردات عينة البحث وفق متغير العمل الحالي

\begin{tabular}{|c|c|c|c|}
\hline النسبة & النكرار & \multicolumn{2}{|c|}{ المتغير } \\
\hline$\% 30.1$ & 227 & قائد/ة مدرسة & \multirow{4}{*}{ عمل الحالي } \\
\hline$\% 8.9$ & 67 & مشرف/ة تربوي/ة & \\
\hline$\% 50.1$ & 378 & معلم/ة & \\
\hline \%10.9 & 82 & مرشد/ة طلابي/ة & \\
\hline$\% 100$ & 754 & \multicolumn{2}{|c|}{ الجمموع } \\
\hline
\end{tabular}

تُظهر المؤشرات الإحصائية للتكرارات والنسب المئوية للجدول رقم (10) الخاص بوصف عينة البحث

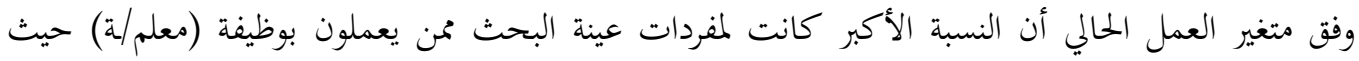

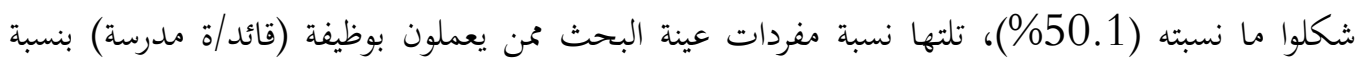
تمثيل بلغت (30.1\%)، أما مفردات عينة البحث الذين يعملون بوظيفة (مرشد/ة طلابي/ة) فمثلوا ما نسبته

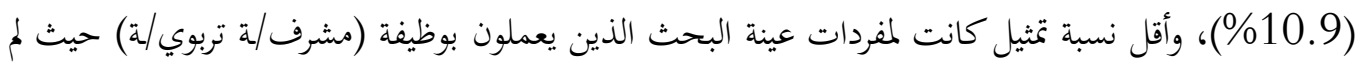
يشكلوا سوى ما نسبته (8.9\%) من مجمل مفردات عينة البحث.

جدول (11): وصف خصائص مفردات عينة البحث وفق متغير عدد سنوات الحبرة

\begin{tabular}{|c|c|c|c|}
\hline النسبة & النكرار & تيغير & \\
\hline$\% 3.6$ & 27 & أقل من خمس سنوات & \multirow{3}{*}{ عدد سنوات الخبرة } \\
\hline$\% 14.5$ & 109 & من خمس سنوات إلى عشر سنوات & \\
\hline$\% 82$ & 618 & أكثر من عشر سنوات & \\
\hline$\% 100$ & 754 & & \\
\hline
\end{tabular}

يتضح من المؤشرات الإحصائية للتكرارات والنسب المئوية للجدول رقم (11) الخاص بوصف عينة

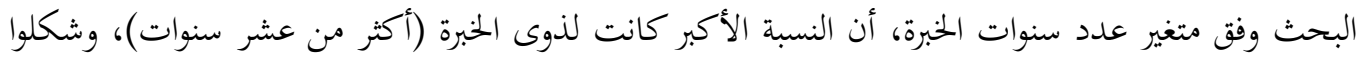

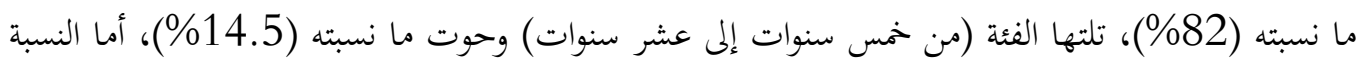

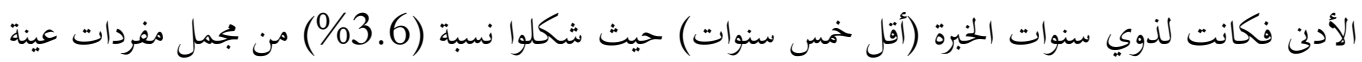
جدول (12): وصف خصائص مفردات عينة البحث وفق متغير النوع

\begin{tabular}{|c|c|c|c|}
\hline النسبة & النكرار & \multicolumn{2}{|c|}{ المتغير } \\
\hline$\% 70.6$ & 532 & بنين & \multirow{2}{*}{ النوع } \\
\hline$\% 29.4$ & 222 & بنات & \\
\hline$\% 100$ & 754 & \multicolumn{2}{|c|}{ الجمهوع } \\
\hline
\end{tabular}




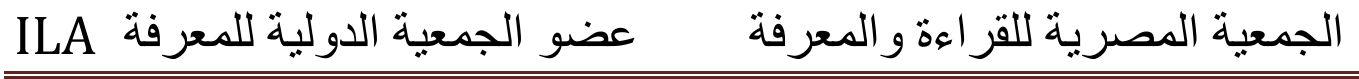

يتبيَّن من المؤشرات الإحصائية للتكرارات والنسب المئوية للجدول رقم (12) الخاص بوصف عينة البحث

وفق متغير النوع أن النسبة الأعلى من مفردات عينة البحث كانت للذكور وشكلوا ما نسبته (70.6\%)، أما نسبة الإناث فبلغت (29.4\%) من مجمل مفردات عينة البحث.

$$
\text { ج) طريقة تقدير الدرجات لفقرات الاستبانة: }
$$

نظراً لأن الفقرات جميعها ايجابية فقد تم اعطاء وزن مدرج وفق مقياس ليكرت الخماسي لكل فقرة، فإن كانت الإجابة كبيرة جداً يعطى خمس درجات، وإن كانت الإجابة كبيرة يعطى أربع درجات، وإن كانت الإجابة متوسطة يعطى ثلاث درجات، وإن كانت الإجابة منخفضة يعطى درجتان، وإن كانت معدومة يعطى درجة واحدة فقط.

خامساً: أساليب المعالجة الإحصائية:

لخدمة أغراض البحث وتحليل البيانات التي تم الحصول عليها، أستخدم عدد من الأساليب الإحصائية المناسبة باستخدام الحزم الإحصائية للعلوم الاجتماعية التي يُرمز إليها اختصارًا بالرمز (SPSS)، وفيما يلي مجموعة الأساليب الإحصائية التي تم استخدامها:

\section{الأساليب التي استخدمت في التحقق من صلاحية الاستبانة للتطبيق:}

1) معامل ارتباط بيرسون (Pearson Correlation)؛ للتحقق من صدق أداة البحث.

2) معامل ألفاكرونباخ (Cronbach's Alpha)؛ لاختبار مدى ثبات أداة البحث.

الأساليب التي استخدمت في الإجابة عن أسئلة البحث:

1) التكرارات والنسب المئوية (frequencies and percentages)؛ لوصف خصائص مفردات عينة

$$
\text { البحث، وتحديد استجاباقم بحاه عبارات المحاور التي تتضمّنها أداة البحث. }
$$

2) المتوسط الحسابي الموزون " المرجح" (Weighted Mean)؛ لمعرفة مدى ارتفاع أو الخفاض استجابات

مفردات عينة البحث عن كل عبارة من عبارات محاور أداة البحث، مع العلم بأنه يفيد في ترتيب

$$
\text { العبارات حسب أعلى متوسط حسابي موزون. }
$$




\section{الجمعية المصرية للقراعة والمعرفة عضو الجمعية الدولية للمعرفة ILA}

3) المتوسط الحسابي (Mean)؛ للتعرّف على مدى ارتفاع أو الخفاض استجابات مفردات عينة البحث

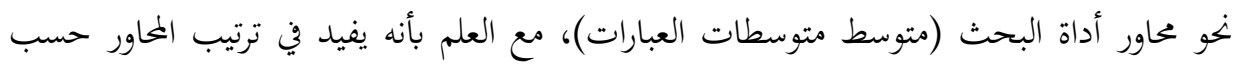
أعلى متوسط حسابي.

4) الانحراف المعياري (Standard deviation)؛ لمعرفة مدى انخراف استجابات مفردات عينة البحث

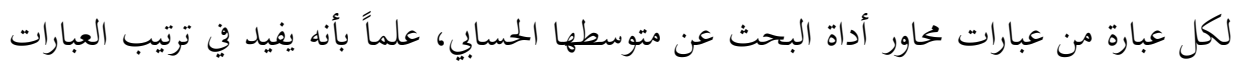

حسب المتوسط الحسابي لصالح أقل تشتت عند تساوي المتوسط الحسابي. 


\section{الفصل الرابع - - الف \\ نتائج البحث ومناقشتها وتفسيرها}

بعد أن عرض الفصل السابق للإجراءات المنهجية للبحث وما جاء فيها من تفصيلاتئات وتهبرما حول منهج

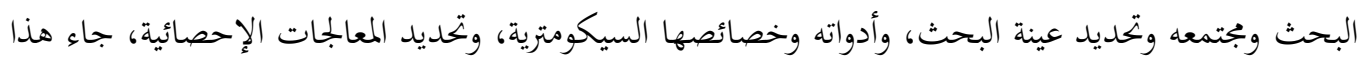

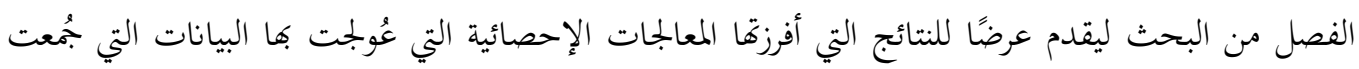

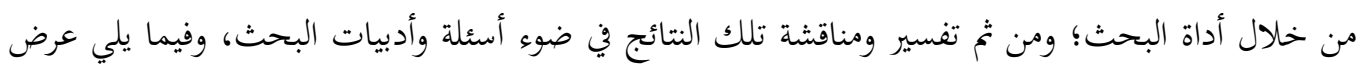
تفصيلي لنتائج الإجابة عن أسئلة البحث.

أولَا: نتائج السؤال الأول للبحث وتفسيرها ومناقشتها:

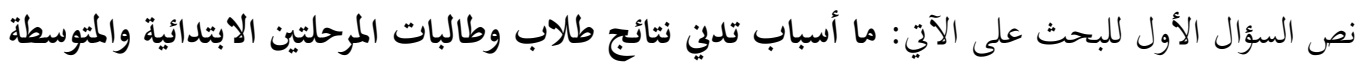

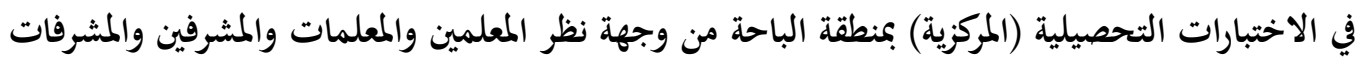

بتعليم منطقة الباحة؟

للإجابة عن هذا السؤال وللتعرّف على أسباب تدني نتائج طلاب وطالبات المرحلتين الابتدائية والمتوسطة

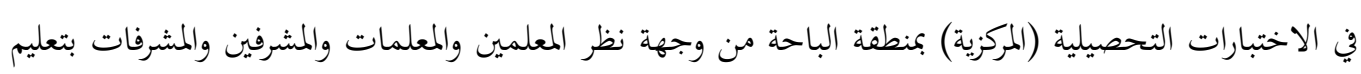

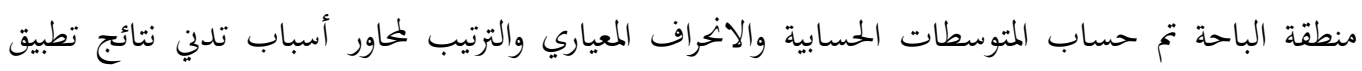

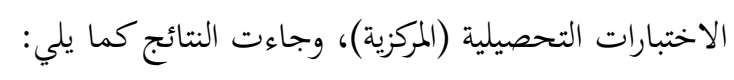

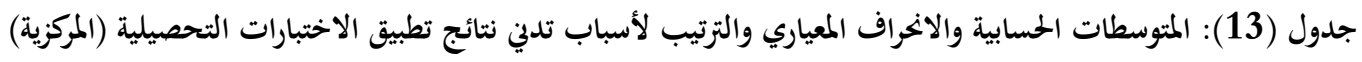

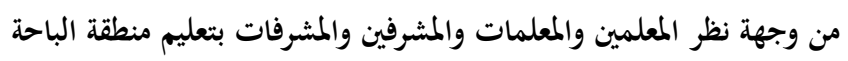

\begin{tabular}{|c|c|c|c|c|}
\hline 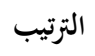 & الانخراف المعياري & المتوسط الحسابي & 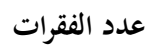 & أسباب تدلي نتائج تطبيق الاختبارات التحصيلية (المركزية) \\
\hline 1 & 0.479 & 3.56 & 15 & العوامل المتعلقة بالمتعلم \\
\hline 2 & 0.760 & 3.31 & 12 & العوامل المتعلقة بالبيئة المدرسية والصفية \\
\hline 3 & 0.794 & 3.13 & 16 & العوامل المتعلقة بالمعلم \\
\hline \multicolumn{2}{|c|}{ الانخراف الممياري= 0.553} & \multicolumn{2}{|c|}{ المتوسط الحسابي العام=3.33 } & الدرجة الكلية لأسباب تدني نتائج تطبيق الاختبارات التحصيلية \\
\hline \multicolumn{4}{|c|}{ درجة الموافقة (متوسطة) } & (المركزية) \\
\hline
\end{tabular}

من خلال تحليل نتائج الجدول رقم (13) يتضح أن المتوسط الحسابي لدرجة موافقة المعلمين والمعلمات

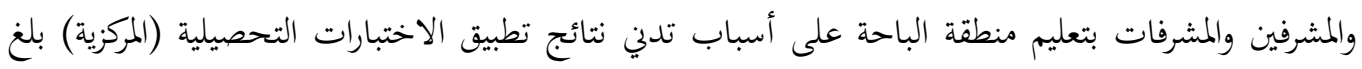


(3,33) من أصل (5) درجات، وهو متوسط يقع في الفئة الثالثة من المقياس المتدرج الخماسي والتي تبدأ

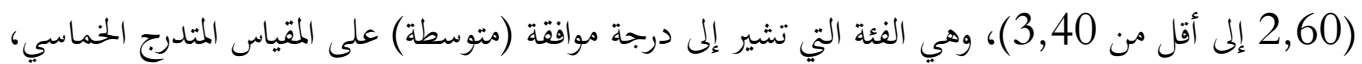
وعند قيام الباحث بترتيب أسباب تدني نتائج تطبيق الاختبارات التحصيلية (المركزية) تبيَّن أن محور (العوامل

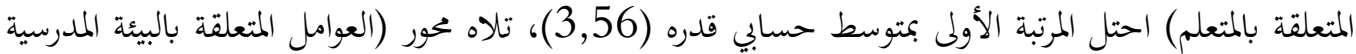

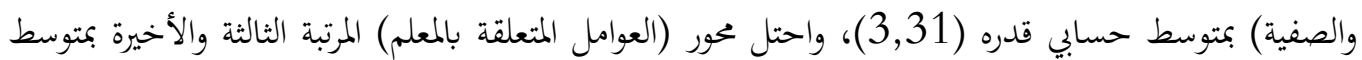

$$
\text { حسابي قدره }(3,13) .
$$

ومن أجل تفسير نتائج السؤال الثاني، تم حساب التكرارات والنسب المئوية والمتوسطات الحسابية والاخرافات المعيارية والرتب لإجابات مفردات تلاتجات عينة البحث لكل عبارة من عبارات محاور أسباب تدني نتائج

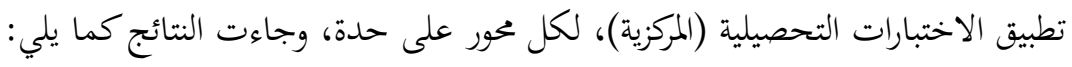
جدول (14): نتائج النكرارات والنسب المئوية والمتوسطات الحسابية والانخرافات المعيارية لإجابات عينة البحث حول الخور الأول (العوامل المتعلقة بالمتعلم)

\begin{tabular}{|c|c|c|c|c|c|c|c|c|c|c|c|}
\hline \multirow{2}{*}{ الموافقة } & \multirow{2}{*}{ المعياري } & \multirow{2}{*}{ المستوسط } & \multicolumn{5}{|c|}{ درجة الموافقة } & \multirow{2}{*}{ والنسب } & \multirow{2}{*}{ 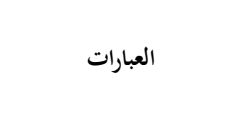 } & \multirow{2}{*}{ ترتيب } & \multirow{2}{*}{ رقمارة } \\
\hline & & & معدومة & منخفضة & متوسطة & كبيرة & كبيرةجدًا & & & & \\
\hline \multirow{2}{*}{ كبيرة جدًا } & \multirow{2}{*}{0.738} & \multirow{2}{*}{4.55} & 5 & 11 & 49 & 184 & 505 & ك) & \multirow{2}{*}{ الشغال المتعلم بالأجهزة } & \multirow{2}{*}{1} & \multirow{2}{*}{10} \\
\hline & & & 0.7 & 1.5 & 6.5 & 24.4 & 67 & $\%$ & & & \\
\hline \multirow{2}{*}{ كبيرة جدًا } & \multirow{2}{*}{0.842} & \multirow{2}{*}{4.27} & 3 & 20 & 114 & 248 & 369 & ك & \multirow{2}{*}{ إهمال المتعلم ملتابعة الدروس } & \multirow{2}{*}{2} & \multirow{2}{*}{4} \\
\hline & & & 0.4 & 2.7 & 15.1 & 32.9 & 48.9 & $\%$ & & & \\
\hline \multirow{2}{*}{ كبيرة جدًا } & \multirow{2}{*}{0.834} & \multirow{2}{*}{4.24} & 2 & 20 & 120 & 261 & 351 & 5) & \multirow{2}{*}{ تدني الدافعية لدى المتعلم } & \multirow{2}{*}{3} & \multirow{2}{*}{6} \\
\hline & & & 0.3 & 2.7 & 15.9 & 34.6 & 46.6 & $\%$ & & & \\
\hline \multirow{2}{*}{ كبيرة } & \multirow{2}{*}{0.865} & \multirow{2}{*}{4.10} & 6 & 21 & 148 & 294 & 285 & S5 & \multirow{2}{*}{ قلة اهتمام ولي الأمر بمتابعة } & \multirow{2}{*}{4} & \multirow{2}{*}{8} \\
\hline & & & 0.8 & 2.8 & 19.6 & 39 & 37.8 & $\%$ & & & \\
\hline \multirow{2}{*}{ كبيرة } & \multirow{2}{*}{0.866} & \multirow{2}{*}{4.02} & 5 & 23 & 176 & 298 & 252 & ك & اعتماد المتعلم كلياً على & & \\
\hline & & & 0.7 & 3.1 & 23.3 & 39.5 & 33.4 & $\%$ & والتطبيقات المتنوعة. & & \\
\hline ك & 0923 & 381 & 8 & 44 & 223 & 283 & 196 & ك & التأثير السلبي للأقران على & 6 & 12 \\
\hline مبيزن & 0.02 & 5.01 & 1.1 & 5.8 & 29.6 & 37.5 & 26 & $\%$ & المتعلم. & 0 & 12 \\
\hline & & & 7 & 38 & 252 & 264 & 193 & ك & ضعف تركيز المتعلم مع & & \\
\hline كبيزة & 0.915 & 3.19 & 0.9 & 5 & 33.4 & 35 & 25.6 & $\%$ & المعلم أثناء الشرح. & 7 & 1 \\
\hline
\end{tabular}




\begin{tabular}{|c|c|c|c|c|c|c|c|c|c|c|c|}
\hline \multirow{2}{*}{ الموافقة } & \multirow{2}{*}{ المعياري } & \multirow{2}{*}{ المستوسط } & \multicolumn{5}{|c|}{ درجة الموافقة } & \multirow{2}{*}{ والنسب } & \multirow{2}{*}{ العبارات } & \multirow{2}{*}{ ت العبارة } & \multirow{2}{*}{ العبارة } \\
\hline & & & معدومة & منخفضة & متوسطة & كبيرة & كبيرةجدًا & & & & \\
\hline \multirow{2}{*}{ كبيرة } & \multirow{2}{*}{1.04} & \multirow{2}{*}{3.54} & 9 & 122 & 245 & 209 & 169 & ك & \multirow{2}{*}{ تمصل داخل الأسرة الأسرية التي } & \multirow{2}{*}{8} & \multirow{2}{*}{9} \\
\hline & & & 1.2 & 16.2 & 32.5 & 27.7 & 22.4 & $\%$ & & & \\
\hline \multirow{2}{*}{ متوسطة } & \multirow{2}{*}{1.12} & \multirow{2}{*}{3.39} & 32 & 138 & 235 & 202 & 147 & ك & \multirow{2}{*}{ للملة الحوافز التشجيعية } & \multirow{2}{*}{9} & \multirow{2}{*}{15} \\
\hline & & & 4.2 & 18.3 & 31.2 & 26.8 & 19.5 & $\%$ & & & \\
\hline \multirow{2}{*}{ متوسطة } & \multirow{2}{*}{1.07} & \multirow{2}{*}{3.38} & 14 & 153 & 268 & 171 & 148 & ك) & \multirow{2}{*}{ كثرة غياب المتعلم عن } & \multirow{2}{*}{10} & \multirow{2}{*}{5} \\
\hline & & & 1.9 & 20.3 & 35.5 & 22.7 & 19.6 & $\%$ & & & \\
\hline \multirow{2}{*}{ متوسطة } & \multirow{2}{*}{1.09} & \multirow{2}{*}{3.14} & 43 & 170 & 281 & 159 & 101 & ك & \multirow{2}{*}{ التعامل مع ورقة الاختبارات } & \multirow{2}{*}{11} & \multirow{2}{*}{14} \\
\hline & & & 5.7 & 22.5 & 37.3 & 21.1 & 13.4 & $\%$ & & & \\
\hline \multirow{2}{*}{ متوسطة } & 101 & 200 & 47 & 146 & 333 & 154 & 74 & S & الحوف والقلق من & 12 & 11 \\
\hline & 1.01 & 0.00 & 6.2 & 19.4 & 44.2 & 20.4 & 9.8 & $\%$ & الاختبارات. & 12 & 11 \\
\hline ith & $10 ?$ & 308 & 35 & 190 & 278 & 179 & 72 & ك5 & التنمر والحالة النفسية & 12 & 13 \\
\hline متوسطة & 1.02 & 0.00 & 4.6 & 25.2 & 36.9 & 23.7 & 9.5 & $\%$ & ل للمتعلم. & 10 & 10 \\
\hline It & 0841 & 261 & 46 & 306 & 321 & 56 & 25 & ك & تدني الوضع الاقتصادي & 11 & 7 \\
\hline & 0.071 & 2.01 & 6.1 & 40.6 & 42.6 & 7.4 & 3.3 & $\%$ & لأسرة المتعلم. & 17 & r \\
\hline منخف & 0.874 & 237 & 92 & 379 & 217 & 45 & 21 & ك & ضعف الحالة الصحية & 15 & 3 \\
\hline ضة & & & 12.2 & 50.3 & 28.8 & 6 & 2.8 & $\%$ & للمتعلم. & (N) & \\
\hline & & & 0,47 & .6 & & & 3,56 & 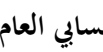 & المتوسط & & \\
\hline & & & & & & 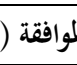 & & & & & \\
\hline
\end{tabular}

من خلال تحليل نتائج الجدول رقم (14) يتضح ما يلي:

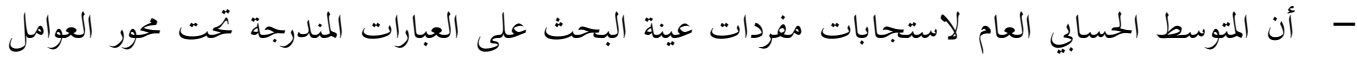

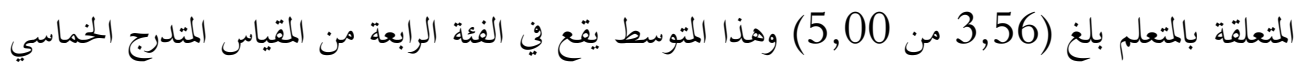

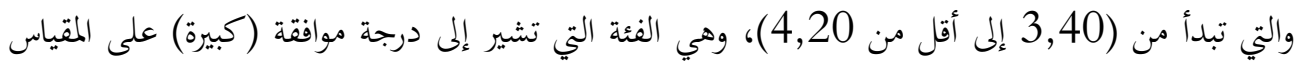
المتدرج الخماسي. - - تراوحت المتوسطات الحسابية لعبارات محور العوامل المتعلقة بالمتعلم ما بين (2,37 - 4,55) درجة من أصل (5) درجات، مما يُشير إلى أن هناك تباين في آراء مفردات عينة البحث حول العوات العوامل المتعلقة

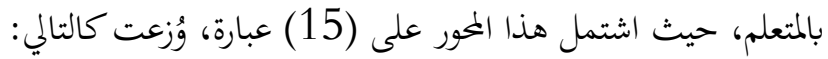


هاءت ثلاث (3) عبارات بدرجة موافقة (كبيرة جدًا) حيث تراوحت المتوسطات الحسابية لهذه

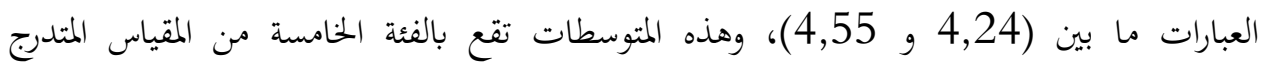

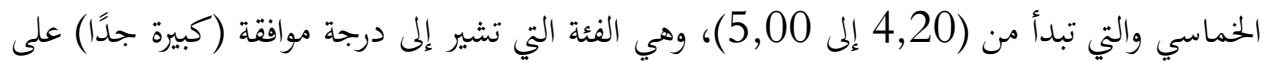
المقياس المتدرج الخماسي. جاءت خمس (5) عبارات بدرجة موافقة (كبيرة) حيث تراوحت المتوسطات الحسابية لمذه العبارات ما بين (3,54 و 4,10)، وهذه المتوسطات تقع بالفئة الرابعة من المقياس المثدرج الخماسي والتي تبدأ من (3.40 إلى أقل من 4,20)، وهي الفئة التي تشير إلى درجة موافقة (كبيرة) على المقياس المتدرج

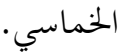
هاءت ست (6) عبارات بدرجة موافقة (متوسطة) حيث تراوحت المتوسطات الحسابية لمذه العبارات

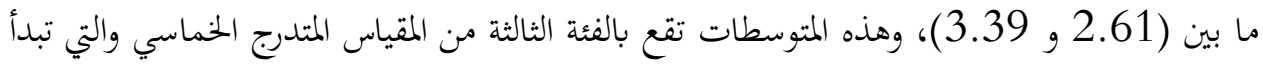
من (2.60 إلى أقل من 3.40)، وهي الفئة التي تشير إلى درجة موافقة (متوسطة) على المقياس باس المتدرج الخماسي. جاءت عبارة واحدة بدرجة موافقة (منخفضة) وهي العبارة رقم (3) والتي تنص على اضعف الحالة الصحية للمتعلمه، بمتوسط حسابي (2.37)، وهذا المتوسط يقع بالفئة الثانية من المقياس المتثدرج الخماسي والتي تبدأ من (1,80 إلى أقل من 2,60)، وهي الفئة التي تشير إلى درجة موافقة (منخفضة) على المقياس المتدرج الخماسي. ويمكن من خلال الجدول الموضح أعلاه أن نقوم بترتيب عبارات محور (العوامل المتعلقة بالمتعلم) ترتيبًا تنازليًا من حيث درجة الموافقة كما يلي:

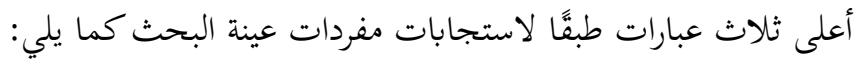
- - استجابات مفردات عينة البحث على العبارة رقم (10) والتي تنص على ا(انشغال المتعلم بالأجهزة الذكية

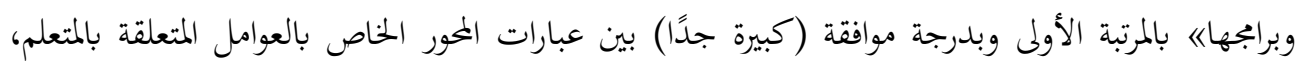
بمتوسط حسابي (4,55) وانحراف معياري (0,738).

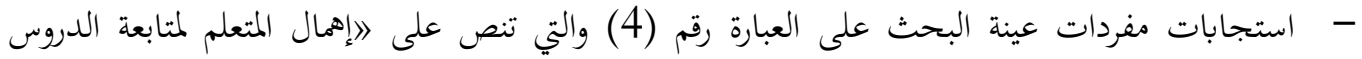

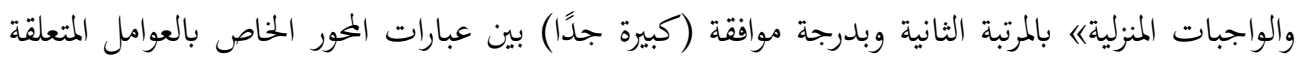
بالمتعلم، بمتوسط حسابي (4,27) وانخراف معياري (0,842). 
- - استجابات مفردات عينة البحث على العبارة رقم (6) والتي تنص على اتدني الدافعية لدى المتعلم نحو

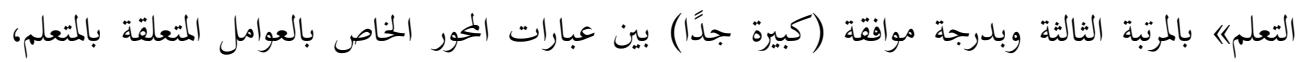

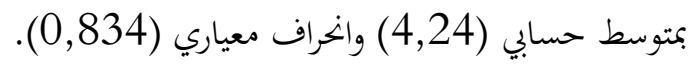

أما أدنى ثلاث عبارات طبقًا لاستجابات مفردات عينة البحث فكانت كما يلي:

- - استجابات مفردات عينة البحث على العبارة رقم (13) والتي تنص على 》التنمر والحالة النفسية للمتعلمه

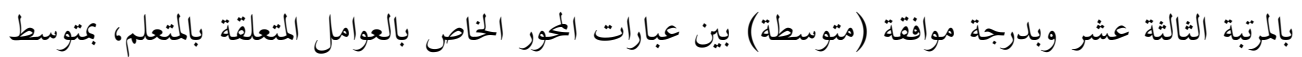

$$
\text { حسابي (3,08) وانحراف معياري (1,02). }
$$

- - استجابات مفردات عينة البحث على العبارة رقم (7) والتي تنص على التدين الوضع الاقتصادي لأسرة

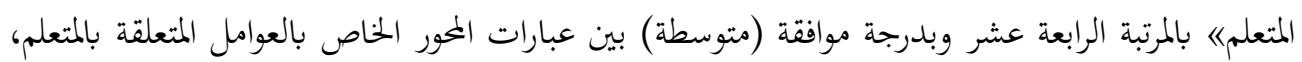

$$
\text { بمتوسط حسابي (2.61) وانحراف معياري (0,841). }
$$

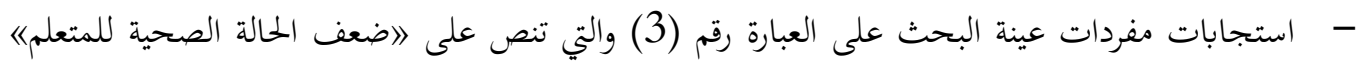

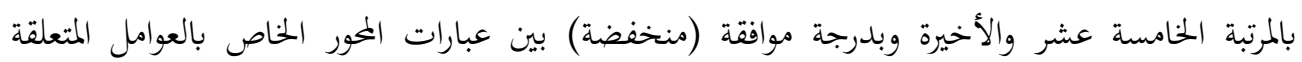

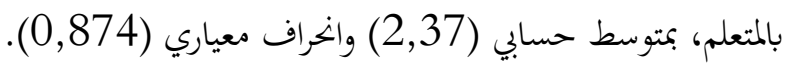

ومن خلال النظر إلى قيم الانحراف المعياري في الجدول رقمر (12) يتبيّن أن قيم الانحراف المعياري لعبارات محور العوامل المتعلقة بالمتعلم تراوحت بين (1,738- 1,12) وكان أقل انحراف معياري للعبارة رقم

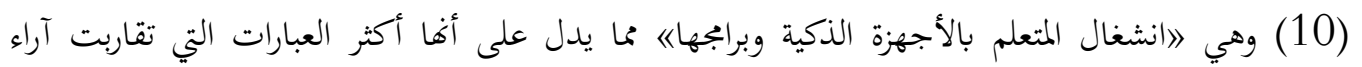

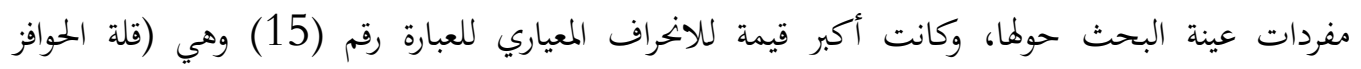

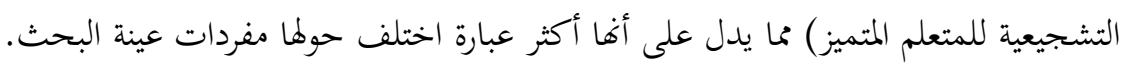

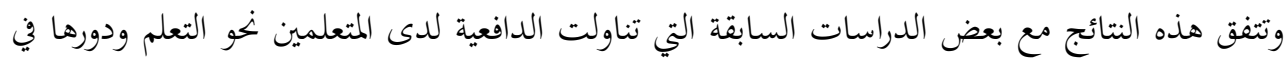

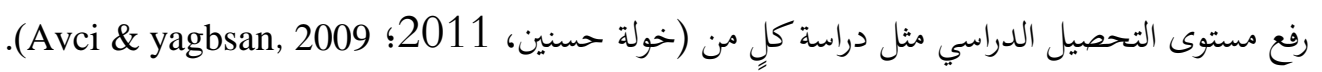
ويمكن تفسير هذه النتيجة كما يلي:

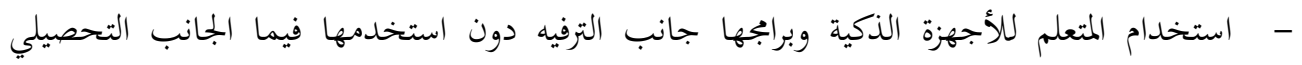

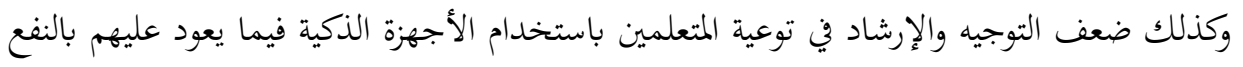

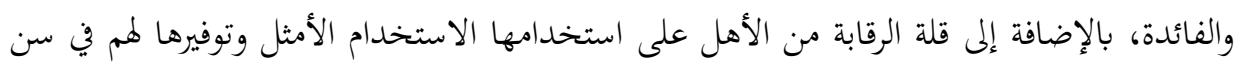
مبكر دون توجيه. 


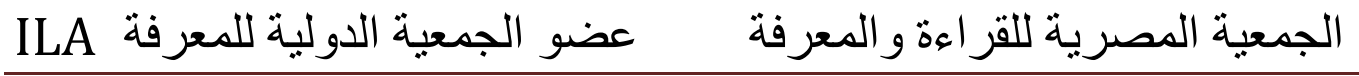

- قلة الاهتمام والمتابعة من قبل قائد المدرسة والمرشد الطلابي والمعلمين وأولياء الامور في الواجبات

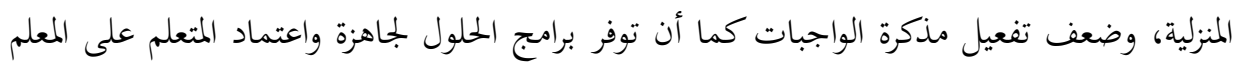

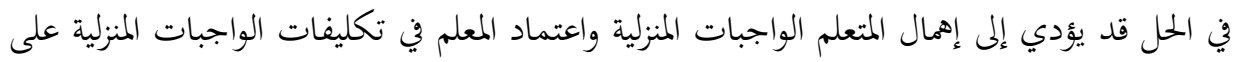
الكم دون الكيف وافتقارها لإشباع رغبات وميول المتعلمين وخلوها من الابتكار والإبداع.

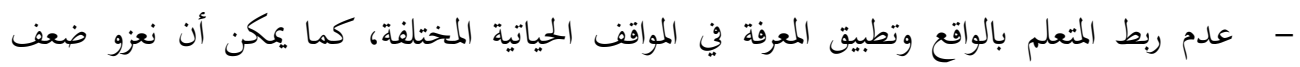
التحصيل الى العديد من المشاكل الأسرية كالطلاق والانفصال والوفاة والظروف المادية للأسرة.

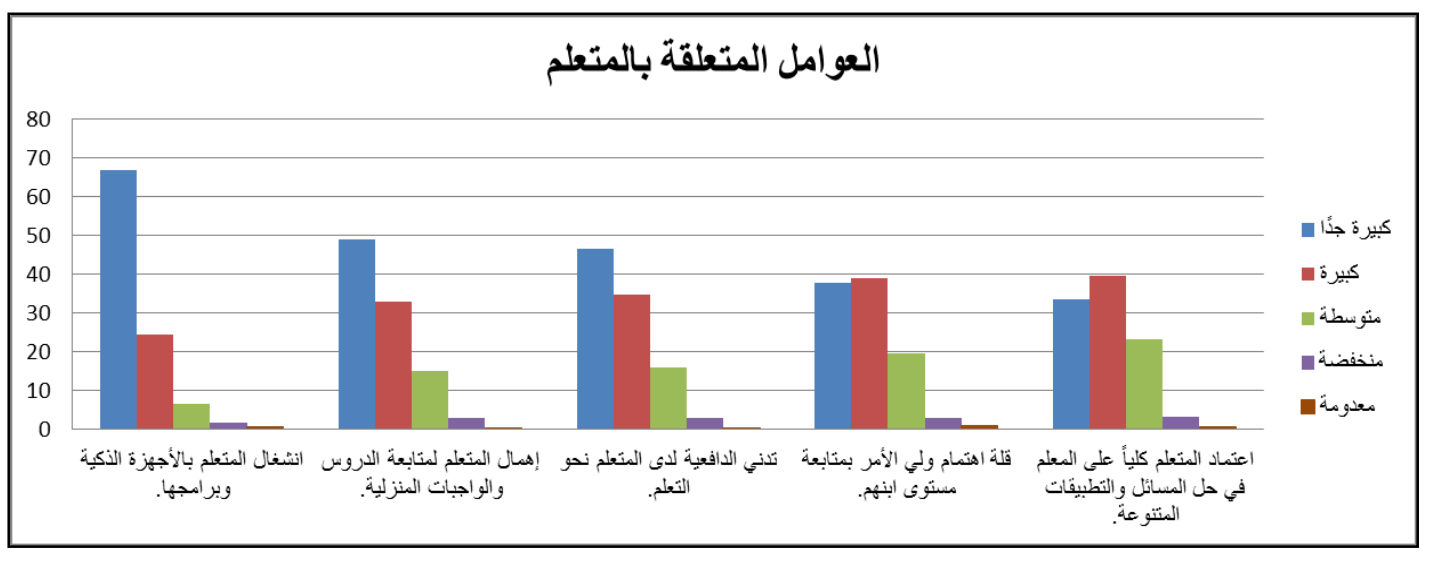

شكل (2): النسب المئوية لأعلى خمس عبارات بالمور الأول (العوامل المتعلقة بالمتعلم) من حيث درجة الموافقة طبقًا لاستجابات مفردات عينة البحث

جدول (15): نتائج النكرارات والنسب المئوية والمثوسطات الحسابية والانحرافات المعيارية لإجابات عينة البحث حول الخحور الثاني (العوامل المتعلقة بالمعلم)

\begin{tabular}{|c|c|c|c|c|c|c|c|c|c|c|c|}
\hline \multirow{2}{*}{ الموافقة } & \multirow{2}{*}{ الانمعياري } & \multirow{2}{*}{ المسابي } & \multicolumn{5}{|c|}{ درجة الموافقة } & \multirow{2}{*}{ والنكرارات } & \multirow{2}{*}{ العبارات } & \multirow{2}{*}{ ترتيب } & \multirow{2}{*}{ العبارة } \\
\hline & & & معدومة & منخفضة & متوسطة & كبيرة & كبيرة & & & & \\
\hline \multirow{2}{*}{ كبيرة } & \multirow{2}{*}{1.24} & \multirow{2}{*}{3.77} & 42 & 96 & 147 & 180 & 289 & ك & \multirow{2}{*}{ إسناد تدريس المواد لغير } & \multirow{2}{*}{1} & \multirow{2}{*}{13} \\
\hline & & & 5.6 & 12.7 & 19.5 & 23.9 & 38.3 & $\%$ & & & \\
\hline \multirow{2}{*}{ كبيرة } & \multirow{2}{*}{1.09} & \multirow{2}{*}{3.44} & 32 & 115 & 233 & 233 & 141 & ك & \multirow{2}{*}{ ضعف تطبيق أدوات } & \multirow{2}{*}{2} & \multirow{2}{*}{16} \\
\hline & & & 4.2 & 15.3 & 30.9 & 30.9 & 18.7 & $\%$ & & & \\
\hline \multirow{2}{*}{ كبيرة } & \multirow{2}{*}{1.05} & \multirow{2}{*}{3.43} & 30 & 111 & 238 & 251 & 124 & ك) & \multirow{2}{*}{ ضلتعلّّ عهارة إثارة الدافعية } & \multirow{2}{*}{3} & \multirow{2}{*}{15} \\
\hline & & & 4 & 14.7 & 31.6 & 33.3 & 16.4 & $\%$ & & & \\
\hline متوسطة & 1.08 & 3.34 & 41 & 123 & 244 & 233 & 113 & ك & قلة ربط المادة العلمية & 4 & 14 \\
\hline
\end{tabular}




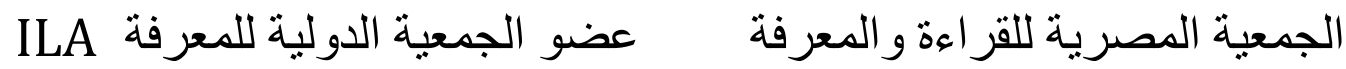

\begin{tabular}{|c|c|c|c|c|c|c|c|c|c|c|c|}
\hline \multirow{3}{*}{ الموافقة } & \multirow{3}{*}{ المعياري } & \multirow{3}{*}{ الملمسابي } & \multicolumn{5}{|c|}{ درجة الموافقة } & \multirow{2}{*}{ والنكرارات } & \multirow{3}{*}{ بالحياة اليومية للمتعلم. } & \multirow{3}{*}{ ترتيب } & \multirow{3}{*}{ العبارة } \\
\hline & & & 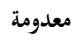 & منخفضة & متوسطة & كبيرة & كبيرة & & & & \\
\hline & & & 5.4 & 16.3 & 32.4 & 30.9 & 15 & $\%$ & & & \\
\hline \multirow{2}{*}{ متوسطة } & \multirow{2}{*}{1.07} & \multirow{2}{*}{3.21} & 45 & 144 & 261 & 217 & 87 & ك & \multirow{2}{*}{ 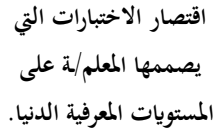 } & \multirow{2}{*}{$\mathbf{5}$} & \multirow{2}{*}{8} \\
\hline & & & 6 & 19.1 & 34.6 & 28.8 & 11.5 & $\%$ & & & \\
\hline \multirow{2}{*}{ متوسطة } & \multirow{2}{*}{1.08} & \multirow{2}{*}{3.18} & 52 & 147 & 247 & 228 & 80 & 5 & \multirow{2}{*}{ عدم تنويع المعلم لأساليب } & \multirow{2}{*}{6} & \multirow{2}{*}{9} \\
\hline & & & 6.9 & 19.5 & 32.8 & 30.2 & 10.6 & $\%$ & & & \\
\hline \multirow{2}{*}{ 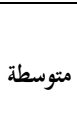 } & \multirow{2}{*}{1.08} & \multirow{2}{*}{3.16} & 46 & 153 & 284 & 172 & 99 & 5 & \multirow{2}{*}{ قلملة البرامج المنفذة لتحقيق } & \multirow{2}{*}{7} & \multirow{2}{*}{2} \\
\hline & & & 6.1 & 20.3 & 37.7 & 22.8 & 13.1 & $\%$ & & & \\
\hline \multirow{2}{*}{ متوسطة } & \multirow{2}{*}{1.09} & \multirow{2}{*}{3.12} & 55 & 165 & 246 & 209 & 79 & ك & \multirow{2}{*}{ استخدام المعلم لأسلوب } & \multirow{2}{*}{8} & \\
\hline & & & 7.3 & 21.9 & 32.6 & 27.7 & 10.5 & $\%$ & & & \\
\hline & 100 & 200 & 68 & 147 & 267 & 201 & 71 & ك & قلة تحفيز المعلم & 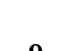 & 10 \\
\hline & & & 9 & 19.5 & 35.4 & 26.7 & 9.4 & $\%$ & للمتعلمين. & & \\
\hline & 100 & 201 & 66 & 161 & 271 & 188 & 68 & s & عدم مراعاة الفروق & 10 & 11 \\
\hline & & & 8.8 & 21.4 & 35.9 & 24.9 & 9 & $\%$ & الفردية لدى المتعلمين. & & \\
\hline & & & 55 & 187 & 264 & 181 & 67 & ك & قلة استخدام المعلم//ـــة & & \\
\hline متوسطة & 1.06 & 3.02 & 7.3 & 24.8 & 35 & 24 & 8.9 & $\%$ & الحديثة في التدريس. & 11 & \\
\hline & & & 58 & 194 & 243 & 197 & 62 & ك & ضعف إلمام المعلم/ـة & & \\
\hline متوسطة & 1.07 & 3.01 & 7.7 & 25.7 & 32.2 & 26.1 & 8.2 & $\%$ & باستراتيجيات التدريس & 12 & 5 \\
\hline & & & 72 & 213 & 254 & 144 & 71 & ك & ضعف إلمام المعلم/_ـــة & & \\
\hline & & & 9.5 & 28.2 & 33.7 & 19.1 & 9.4 & $\%$ & بأهداف المنهج المطور . & & \\
\hline F & 104 & 288 & 61 & 221 & 270 & 151 & 51 & ك) & عدم قدرة المعلم على & 14 & 4 \\
\hline & & & 8.1 & 29.3 & 35.8 & 20 & 6.8 & $\%$ & إدارة الصف بنجاح. & & \\
\hline & & & 66 & 217 & 270 & 144 & 57 & ك & ضعف الاعداد الأكادي & & \\
\hline & & & 8.8 & 28.8 & 35.8 & 19.1 & 7.6 & $\%$ & للمعلم/سـة & & \\
\hline
\end{tabular}




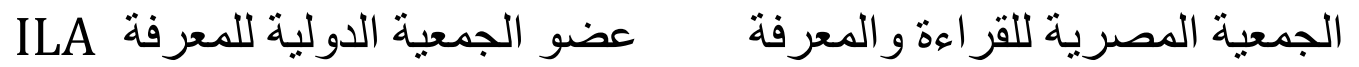

\begin{tabular}{|c|c|c|c|c|c|c|c|c|c|c|c|}
\hline \multirow{2}{*}{ الموافقة } & \multirow{2}{*}{ الالمعراف } & \multirow{2}{*}{ المسابي } & \multicolumn{5}{|c|}{ درجة الموافقة } & \multirow{2}{*}{ والنكرارات } & \multirow{2}{*}{ العبارات } & \multirow{2}{*}{ العبارة } & \multirow{2}{*}{ العبارة } \\
\hline & & & معدومة & منخفضة & متوسطة & كبيرة & كبيرة & & & & \\
\hline \multirow{2}{*}{ منخفضة } & \multirow{2}{*}{0.900} & \multirow{2}{*}{2.56} & 83 & 279 & 297 & 78 & 17 & ك & \multirow{2}{*}{ قلة التدريسية للمعلم/_سـة. } & \multirow{2}{*}{16} & \multirow{2}{*}{3} \\
\hline & & & 11 & 37 & 39.4 & 10.3 & 2.3 & $\%$ & & & \\
\hline \multicolumn{12}{|c|}{ الانخراف المعياري=0.794 } \\
\hline & & & & & & & & & & & \\
\hline
\end{tabular}

$$
\text { من خلال تحليل نتائج الجدول رقم (15) يتضح ما يلي: }
$$

- - أن المتوسط الحسابي العام لاستجابات مفردات عينة البحث على العبارات المندرجة تحت محور العوامل

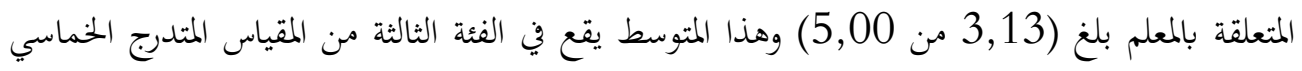
والتي تبدأ من (2,60 إلى أقل من 3,40)، وهي الفئة التي تشير إلى درجة موافقة (متوسطة) على

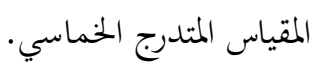
- - تراوحت المتوسطات الحسابية لعبارات محور العوامل المتعلقة بالمعلم ما بين (2,56 - 3,77) درجة من

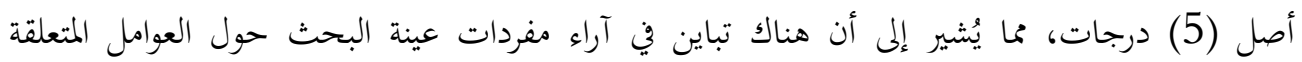

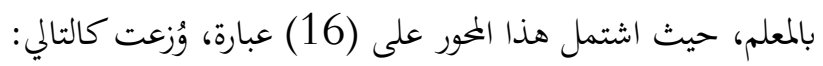
هاءت ثلاث (3) عبارات بدرجة موافقة (كبيرة) حيث تراوحت المتوسطات الحسابية لمذه العبارات

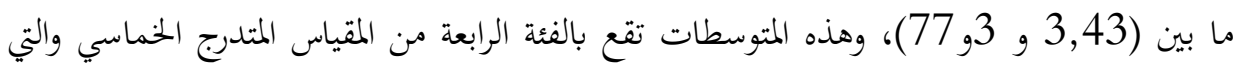

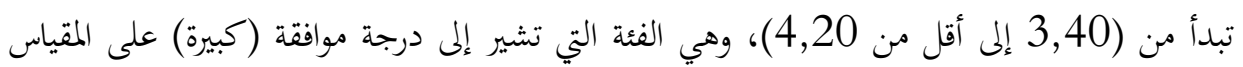
المتدرج الخماسي. جاءت اثنتا عشرة (12) عبارة بدرجة موافقة (متوسطة) حيث تراوحت المتوسطات الحسابية لهذه

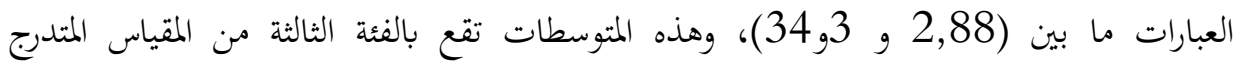

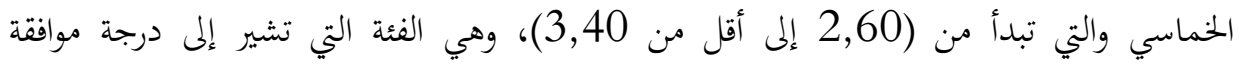
(متوسطة) على المقياس المتدرج الخماسي.

جاءت عبارة واحدة بدرجة موافقة (منخفضة) وهي العبارة رقم (3) والتي تنص على \قلة عدد

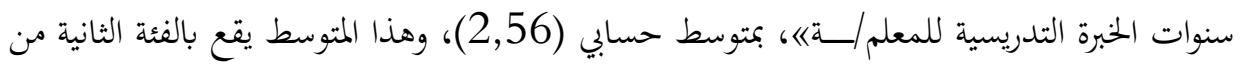




\section{الجمعية المصرية للقر اءة والمعرفة عضو الجمعية الدولية للمعرفة ILA}

المقياس المتدرج الخماسي والتي تبدأ من (1,80 إلى أقل من 2,60)، وهي الفئة التي تشير إلى درجة موافقة (منخفضة) على المقياس المتدرج الخماسي.

ويمكن من خلال الجدول الموضح أعلاه أن نقوم بترتيب عبارات محور (العوامل المتعلقة بالمعلم) ترتيبًا

$$
\text { تنازليًا من حيث درجة الموافقة كما يلي: }
$$

أما أعلى ثلاث عبارات طبقًا لاستجابات مفردات عينة البحث فكانت كما يلي:

- - استجابات مفردات عينة البحث على العبارة رقم (13) والتي تنص على 》إسناد تدريس المواد لغير

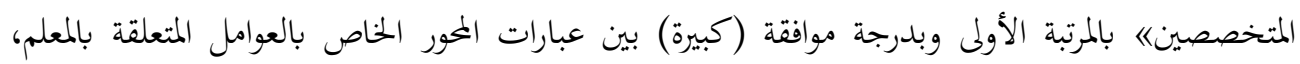

$$
\text { بمتوسط حسابي }(3,77) \text { وانخراف معياري (1,24). }
$$

- - - استجابات مفردات عينة البحث على العبارة رقم (16) والتي تنص على اضعف تطبيق أدوات التقويم

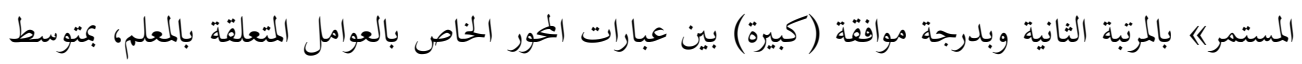

$$
\text { حسابي (3,44) وانحراف معياري (1,09). }
$$

- - استجابات مفردات عينة البحث على العبارة رقم (15) والتي تنص على لاضعف مهارة إثارة الدافعية

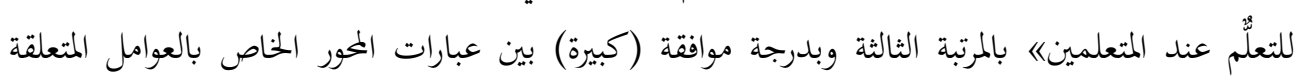
بالمعلم، بمتوسط حسابي (3,43) وانحراف معياري (1,05). وأما أدنى ثلاث عبارات طبقًا لاستجابات مفردات عينة البحث فكانت كما يلي:

- - متجابات مفردات عينة البحث على العبارة رقم (4) والتي تنص على لاعدم قدرة المعلم على إدارة الصف

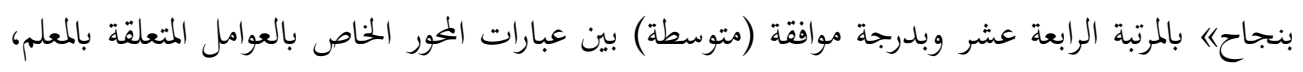
بمتوسط حسابي (2,88) وانخراف معياري (1,04). - - استجابات مفردات عينة البحث على العبارة رقم (1) والتي تنص على لاضعف الإعداد الأكاديمي

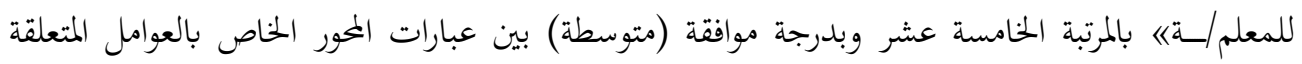
بالمعلم، بمتوسط حسابي $(2,88)$ وانحراف معياري (1,06). 
- - متجابات مفردات عينة البحث على العبارة رقم (3) والتي تنص على القلة عدد سنوات الخبرة التدريسية

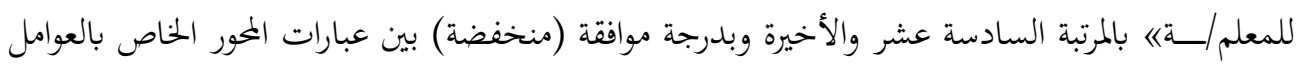

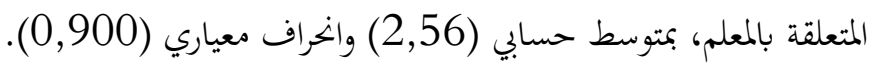

ومن خلال النظر إلى قيم الانراف المعياري في الجدول رقم (13) يتبيّن أن قيم الانخراف المعياري

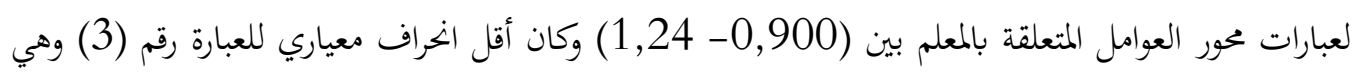

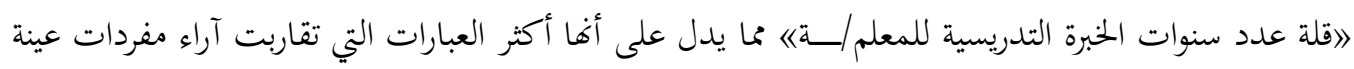

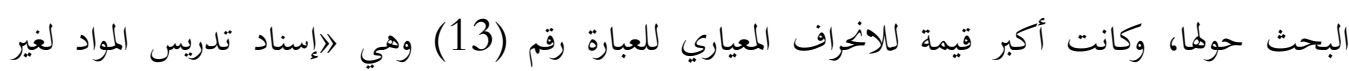

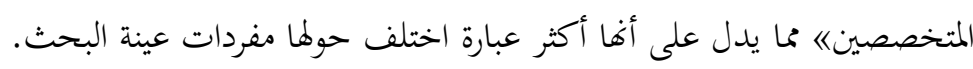

وتتفق هذه النتائج مع بعض الدراسات السابقة التي تناولت الدافعية لدى المتعلمين نخو التعلم ودور

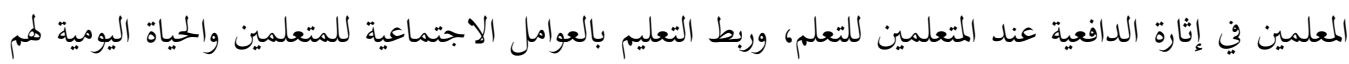

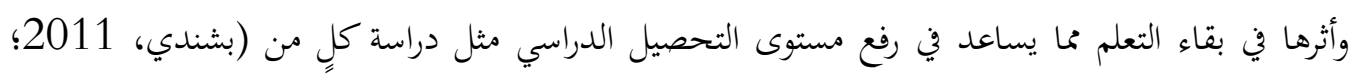
خولة حسنين، 2011). يمكن تفسير هذه النتيجة كما يلي: - مئي

- - قد يكون المعلم سبباً في ضعف التحصيل الدراسي لدى المتعلمين وذلك بإسناد مواد تدريس في

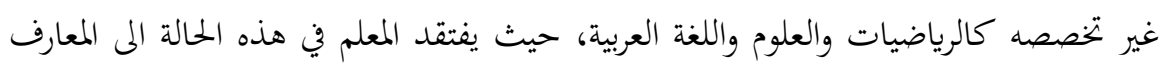

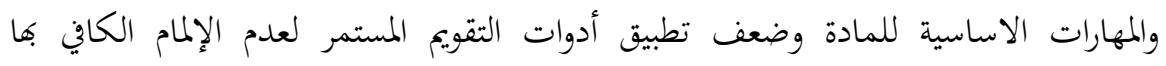
بالإضافة إلى ضعف وجود دورات تدريبية في هذا المجال.

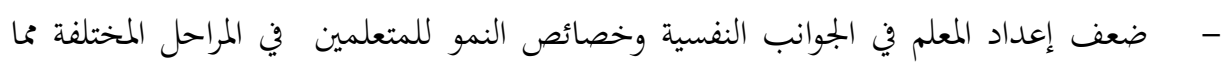

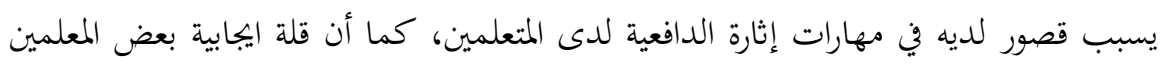
وانتمائه لمهنة التدريس قد تنعكس سلباً على أدائه وإثارته للدافعية عند المتعلمين.

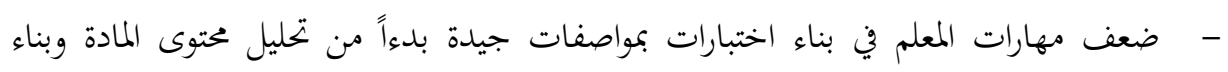
جدول المواصفات وانتهاءً بالأمور الفنية في إخراج ورقة الأسئلة ومضمونها.

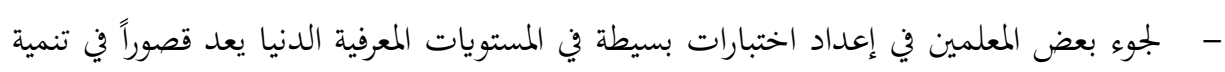

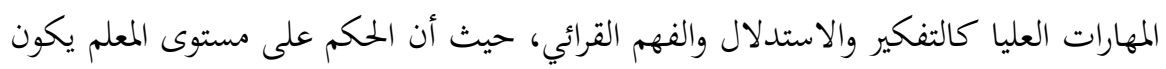
مبنياً على مستوى المتعلمين لديه. 


\section{الجمعية المصرية للقر اعة والمعرفة عضو الجمعية الدولية للمعرفة ILA}

- - كتابة أسئلة الاختبارات تتم عن طريق المعلم فقط دون مراجعتها من قائد المدرسة أو المشرف

$$
\text { التربوي للاطلاع عليها وتقديم التغذية الراجعة. }
$$

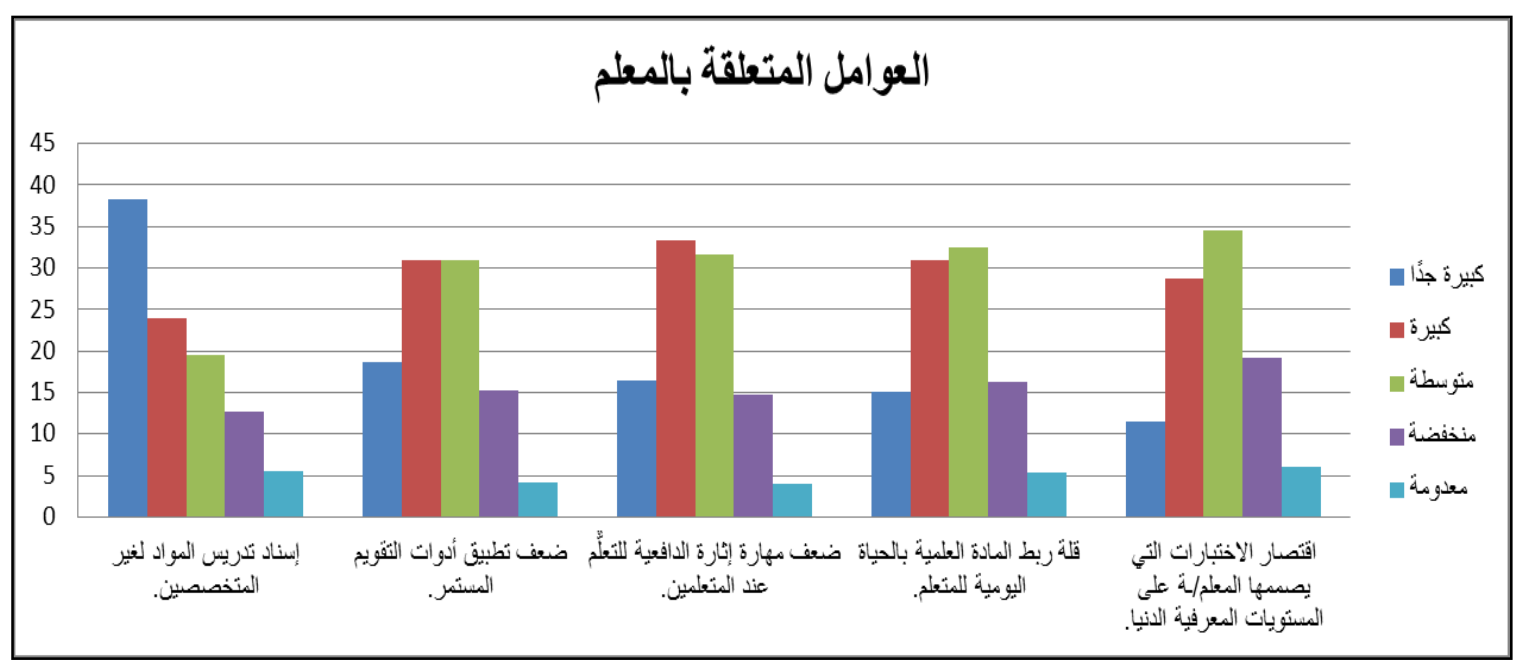

شكل (3): النسب المئوية لأعلى خمس عبارات بالمحور الثاني (العوامل المتعلقة بالمعلم) من حيث درجة الموافقة طبقًا لاستجابات

$$
\text { مفردات عينة البحث }
$$

جدول (16): نتائج النكرارات والنسب المئوية والمتوسطات الحسابية والانخرافات المعيارية لإجابات عينة البحث حول الخور الثالث (العوامل المتعلقة بالبيئة المدرسية والصفية)

\begin{tabular}{|c|c|c|c|c|c|c|c|c|c|c|}
\hline & \\
\hline
\end{tabular}




\section{ILA الجمعية المصرية للقر اءة والمعرفة عضو الجمعية الدولية للمعرفة}

\begin{tabular}{|c|c|c|c|c|c|c|c|c|c|c|c|}
\hline \multirow{3}{*}{ الموافقة } & \multirow{3}{*}{ المعياري } & \multirow{3}{*}{ المستوسط } & \multicolumn{5}{|c|}{ درجة الموافقة } & \multirow{2}{*}{ والنكرارات } & \multirow{3}{*}{ الرياضيات والعلوم. } & \multirow{3}{*}{ ترتيب } & \multirow{3}{*}{ لعبارة } \\
\hline & & & معدومة & منخفضة & متوسطة & كبيرة & كبيرة & & & & \\
\hline & & & 5 & 13.8 & 23.7 & 25.5 & 32 & $\%$ & & & \\
\hline \multirow{2}{*}{ كبيرة } & \multirow{2}{*}{1.07} & \multirow{2}{*}{3.62} & 23 & 86 & 236 & 208 & 191 & ك & \multirow{2}{*}{ التعلم الداعمة للتدريس فئل في } & \multirow{2}{*}{4} & \multirow{2}{*}{8} \\
\hline & & & 3.1 & 11.4 & 31.3 & 28.9 & 25.3 & $\%$ & & & \\
\hline \multirow{2}{*}{ كبيرة } & \multirow{2}{*}{1.08} & \multirow{2}{*}{3.53} & 29 & 101 & 223 & 240 & 161 & 5) & \multirow{2}{*}{ ضالأسفة للعماصل بعلم الألماءرة } & \multirow{2}{*}{5} & \multirow{2}{*}{11} \\
\hline & & & 3.8 & 13.4 & 29.6 & 31.8 & 21.4 & $\%$ & & & \\
\hline \multirow{2}{*}{ كبيرة } & \multirow{2}{*}{1.12} & \multirow{2}{*}{3.44} & 33 & 127 & 222 & 217 & 155 & ك & \multirow{2}{*}{ تلداني الانضباط والالتزام } & \multirow{2}{*}{6} & \multirow{2}{*}{4} \\
\hline & & & 4.4 & 16.8 & 29.4 & 28.8 & 20.6 & $\%$ & & & \\
\hline \multirow{2}{*}{ متوسطة } & \multirow{2}{*}{1.26} & \multirow{2}{*}{3.22} & 79 & 154 & 188 & 186 & 147 & ك & \multirow{2}{*}{ والاعتماد على الملذخصات. } & \multirow{2}{*}{7} & \multirow{2}{*}{5} \\
\hline & & & 10.5 & 20.4 & 24.9 & 24.7 & 19.5 & $\%$ & & & \\
\hline \multirow{2}{*}{ متوسطة } & \multirow{2}{*}{1.18} & & 62 & 165 & 207 & 202 & 118 & ك & عدم تعاون المعلمين في & & \\
\hline & & & 8.2 & 21.9 & 27.5 & 26.8 & 15.6 & $\%$ & للتعلم (القراءة والكتابة) & & \\
\hline & & & 67 & 189 & 242 & 139 & 117 & ك & قلة فاعلية الدور الإرشادي & & \\
\hline مسوسع & & & 8.9 & 25.1 & 32.1 & 18.4 & 15.5 & $\%$ & المستويات التحصيلية لدى & & \\
\hline & & & 117 & 223 & 210 & 119 & 85 & ك & & & \\
\hline سوس & & & 15.5 & 29.6 & 27.9 & 15.8 & 11.3 & $\%$ & وتغييره المستمر. . & & \\
\hline متسطة & 115 & 277 & 93 & 250 & 220 & 119 & 72 & ك & ضعف المتابعة الفنية من & 11 & 10 \\
\hline & & & 12.3 & 33.2 & 29.2 & 15.8 & 9.5 & $\%$ & المعلمين في التدريس & & \\
\hline
\end{tabular}




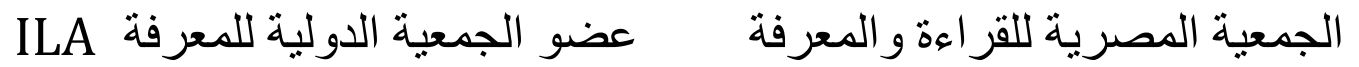

\begin{tabular}{|c|c|c|c|c|c|c|c|c|c|c|c|}
\hline \multirow{2}{*}{ الموافقة } & \multirow{2}{*}{ المعياري } & \multirow{2}{*}{ المستوسط } & \multicolumn{5}{|c|}{ درجة الموافقة } & \multirow{2}{*}{ والنكرارات } & \multirow{2}{*}{ 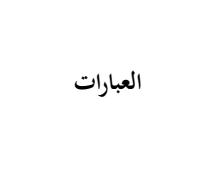 } & \multirow{2}{*}{ ترتيب } & \multirow{2}{*}{ رقم } \\
\hline & & & معدومة & منخفضة & متوسطة & كبيرة كبي & جيدًا & & & & \\
\hline \multirow{2}{*}{ متوسطة } & \multirow{2}{*}{1.21} & \multirow{2}{*}{2.74} & 114 & 251 & 191 & 115 & 83 & ك & \multirow{2}{*}{ تدني مستوى النظافة في } & \multirow{2}{*}{12} & \multirow{2}{*}{9} \\
\hline & & & 15.1 & 33.3 & 25.3 & 15.3 & 11 & $\%$ & & & \\
\hline \multicolumn{12}{|c|}{ الانخراف المعياري=0.760 } \\
\hline
\end{tabular}

من خلال تحليل نتائج الجدول رقم (16) يتضح ما يلي:

- - أن المتوسط الحسابي العام لاستجابات مفردات عينة البحث على العبارات المندرجة تحت محور العوامل

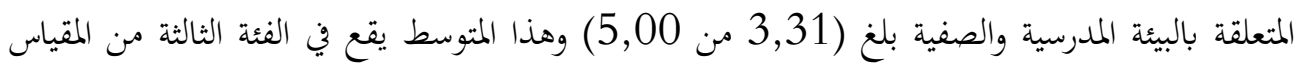

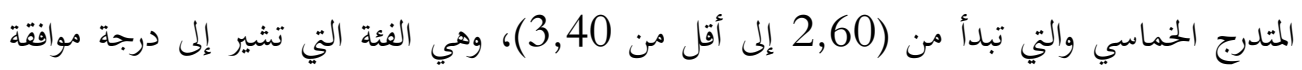
(متوسطة) على المقياس المتدرج الخماسي. تيداس من المني.

- - تراوحت المتوسطات الحسابية لعبارات محور العوامل المتعلقة بالبيئة المدرسية والصفية ما بين (2.74 -

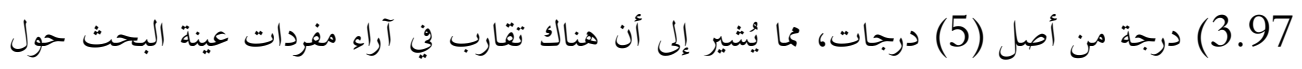

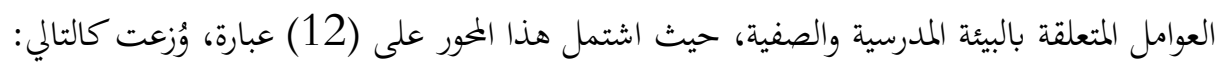
هاءت ست (6) عبارات بدرجة موافقة (كبيرة) حيث تراوحت المتوسطات الحسابية لهذه العبارات

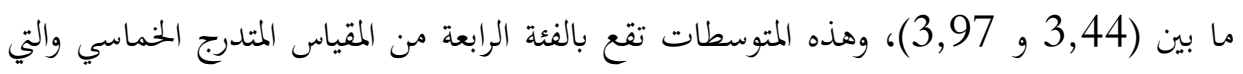

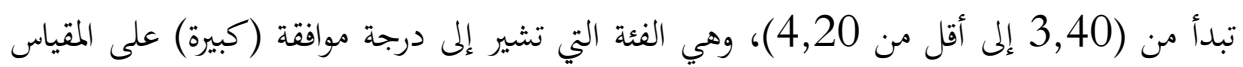
المتدرج الخماسي. جاءت ست (6) عبارات بدرجة موافقة (متوسطة) حيث تراوحت المتوسطات الحسابية لهذه

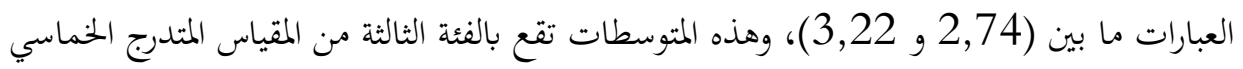

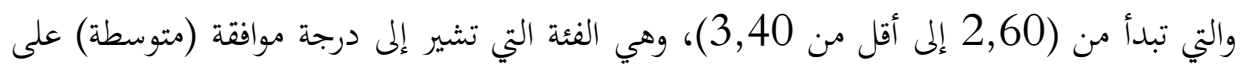

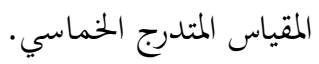




\section{الجمعية المصرية للقر اءة والمعرفة عضو الجمعية الدولية للمعرفة ILA}

ويمكن من خلال الجدول الموضح أعلاه أن نقوم بترتيب عبارات محور (العوامل المتعلقة بالبيئة المدرسية

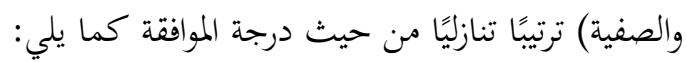
جاءت أعلى ثلاث عبارات طبقًا لاستجابات مفردات عينة البحث كما يلي: - - استجابات مفردات عينة البحث على العبارة رقم (2) والتي تنص على اضعف البنية التحتية والمرافق

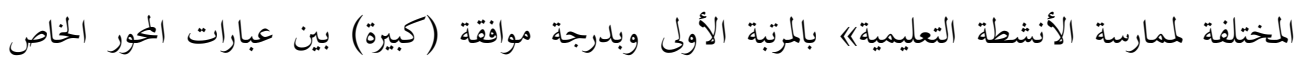

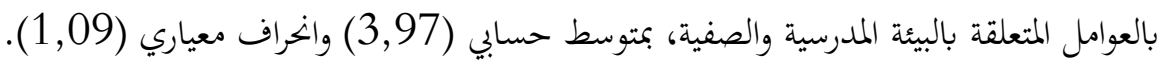
- - استجابات مفردات عينة البحث على العبارة رقم (1) والتي تنص على اكثرة أعداد الطلاب داخل

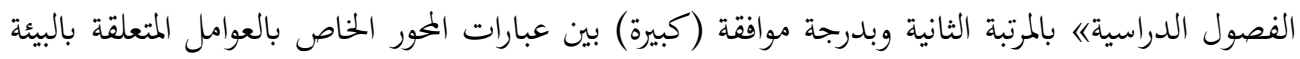

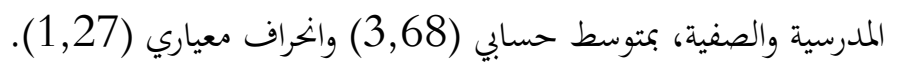

- - استجابات مفردات عينة البحث على العبارة رقم (3) والتي تنص على 》اعدم تفعيل معامل الرياضيات

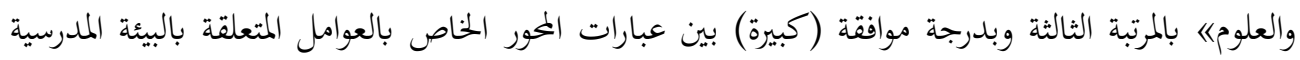

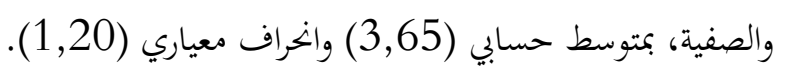

جاءت أدنى ثلاث عبارات طبقًا لاستجابات مفردات عينة البحث كما يلي:

- - استجابات مفردات عينة البحث على العبارة رقم (6) والتي تنص على 》اعدم ثبات الجدول الدراسي

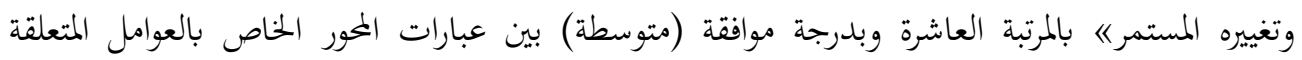
بالبيئة المدرسية والصفية، مبتوسط حسابي (2,78) وانخراف معياري (1,21)

- - متجابات مفردات عينة البحث على العبارة رقم (10) والتي تنص على لاضعف المتابعة الفنية من قبل

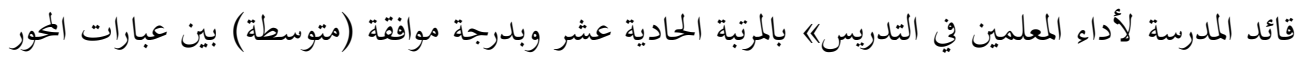

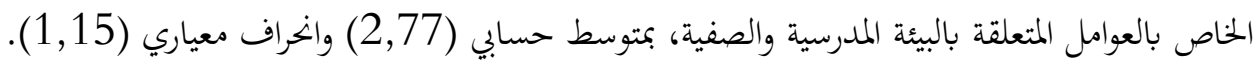
- - استجابات مفردات عينة البحث على العبارة رقم (9) والتي تنص على الدني مستوى النظافة في الفصول

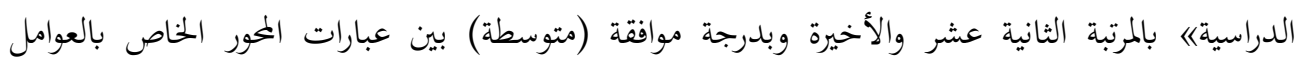
المتعلقة بالبيئة المدرسية والصفية، بمتوسط حسابي (2,74) وانخراف معياري (1,21) 


\section{الجمعية المصرية للقر اءة والمعرفة عضو الجمعية الدولية للمعرفة ILA}

ومن خلال النظر إلى قيم الانحراف المعياري في الجدول رقم (14) يتبيّن أن قيم الانحراف المعياري

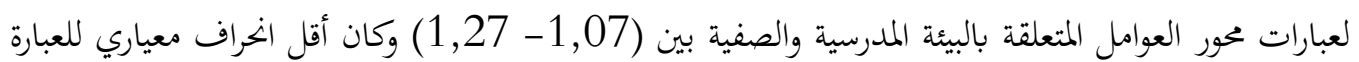

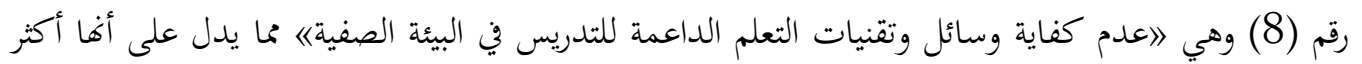

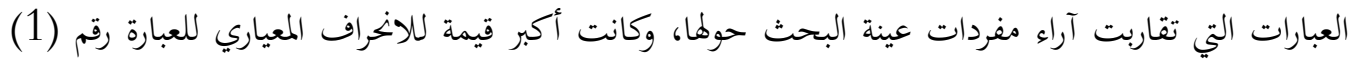

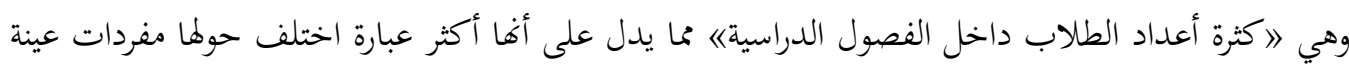
البحث. ويمكن تفسير هذه النتيجة كما يلي:

- - يُعد ضعف البنية التحتية للمرافق المختلفة لممارسة الأنشطة التعليمية سبيًا في تدني مستوى التحصيل

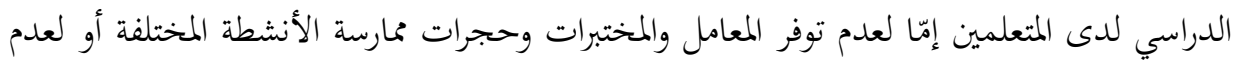

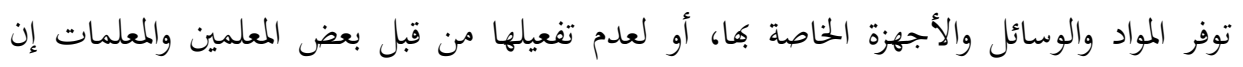
توفرت. - اختلاف مفهوم (كثرة المتعلمين) من مدرسة لأخرى حسب مساحة الفصل وبالتالي لا يمكن الجزم

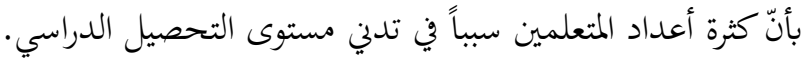

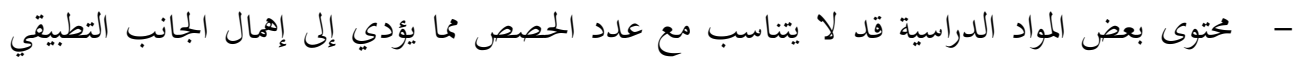

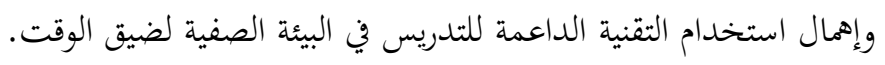

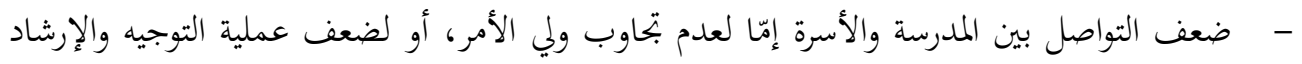
داخل المدرسة. 


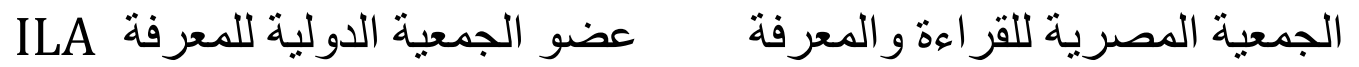

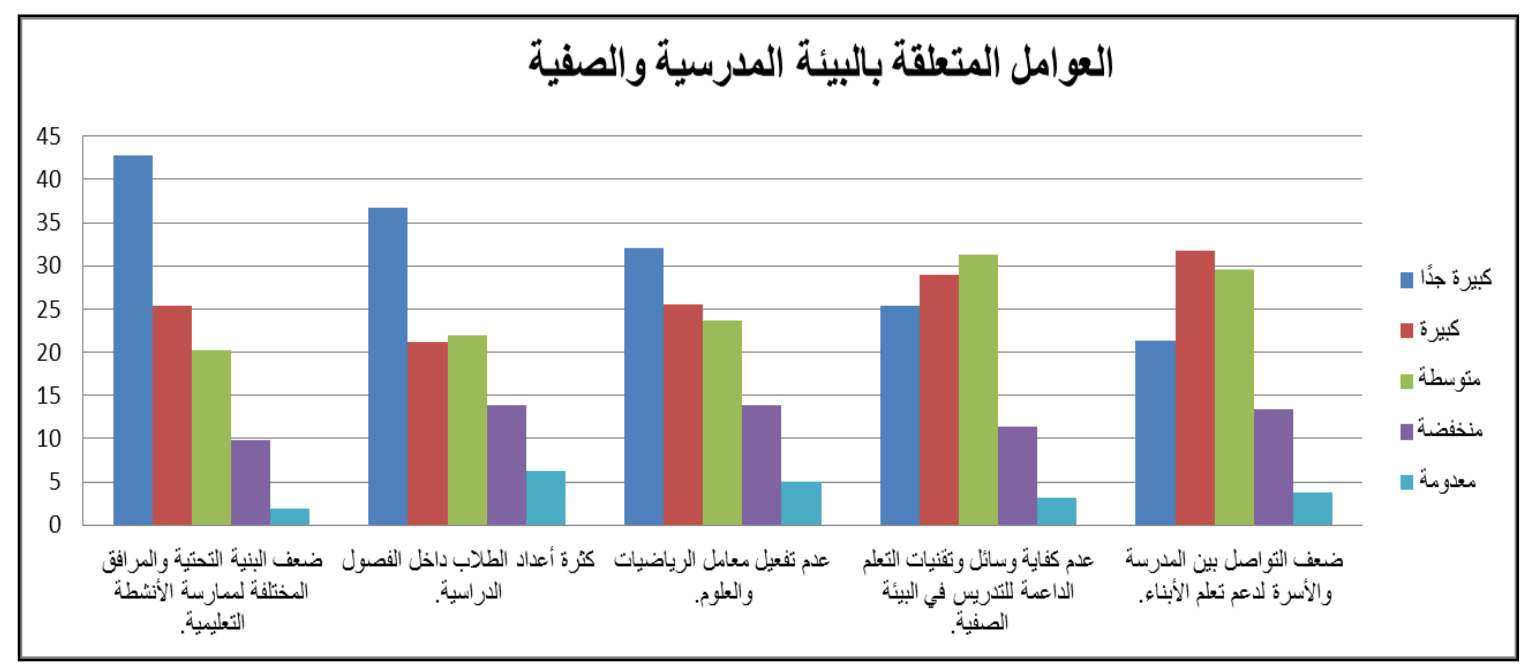

شكل (4): النسب المئوية لأعلى خمس عبارات بالمور الثالث (العوامل المتعلقة بالبيئة المدرسية والصفية) من حيث درجة الموافقة

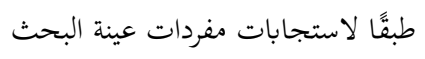

ومن خلال ما سبق من النتائج التي توصل لما البحث والدراسات السابقة التي دعمت نتائج البحث

وكذلك من خلال ما توصل له بعض المشرفين من تجربتهم الميدانية أثناء تطبيق الاختبارات التحصيلية (المركزية) خلال الأسبوع الخامس عشر من الفصل الدراسي الثاني للعام الدراسي 1440هـ، وأراء بعض قادة المدارس ومعلمي المواد المستهدفة فإن هذا التدني في مستوى التحصيل الدراسي للاختبارات التحصيلية (المركزية) يمكن أن يعزى إلى الأسباب السابقة بالإضافة إلى ما تم التوصل له من خلال التطبيق الميداني ومنها: - ـ وقت تطبيق الاختبارات كان متأخر جداً حيث طبق في الأسبوع الخامس عشر من الدراسة وهو وقت متأخر جداً، مما أضاف عبئاً على المتعلمين. - - عدم حرص بعض المتعلمين وأولياء الأمور على مثل هذا النوع من الاختبارات لعدم ربطه برسوب أو نجاح - - عدم الجدية في التطبيق من بعض المدارس من حيث الاهتمام بوضوح الطباعة والتصوير لأوراق الأسئلة والإجابة. - - قلة عدد المشرفين/ ات التربويين لمتابعة الاختبارات التحصيلية (المركزية) والإشراف عليها. - - اختلاف ابعاد ورقة الإجابة عما يجب أن تكون عليه في جهاز (ريمارك) مما شكل استبعاد بجموعة من إجابات الطلاب. 
- - معف التهيئة والاستعداد في الميدان التربوي قبل تطبيق الاختبارات التحصيلية (المركزية).

ثانياً: نتائج السؤال الثاني للدراسة وتفسيرها ومناقشتها

نص السؤال الثاني للدراسة على الآتي: ما التصور المقترح لمعالجة أسباب تدلي نتائج تطبيق الاختبارات

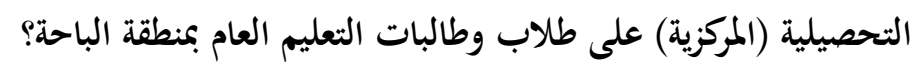

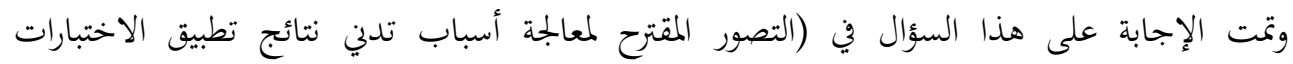

$$
\text { التحصيلية (المركزية) على طلاب وطابلات التعليم العام بمنطقة الباحة). }
$$

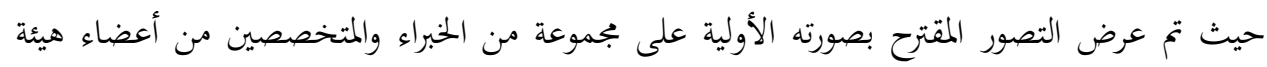

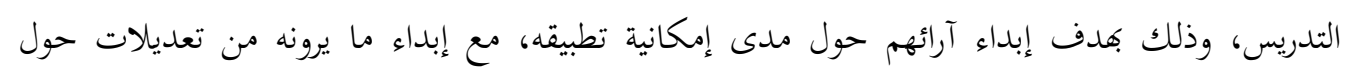

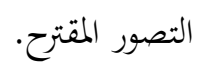

المدف العام:

تجويد أداء المتعلمين في الاختبارات التحصيلية (المركزية)

$$
\text { الأهداف التفصيلية: }
$$

2) الديب الطلاب والطالبات على نماذج من الأدوات التقويمية المستخدمة في الاختبارات التحرية التحصيلية

$$
\text { (المركزية). }
$$

3) تدريب المعلمين والمعلمات على استخدام أساليب وطرائق التدريس التي تنمي مهارات التفكر العليا. - الع

$$
\text { تدريب المعلمين والمعلمات على بناء اختبارات تحصيلية بمواصفات جيدة. }
$$

التحليل الرباعي SWOT (البيئة الداخلية والخارجية):

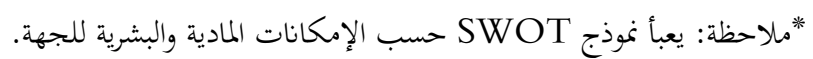

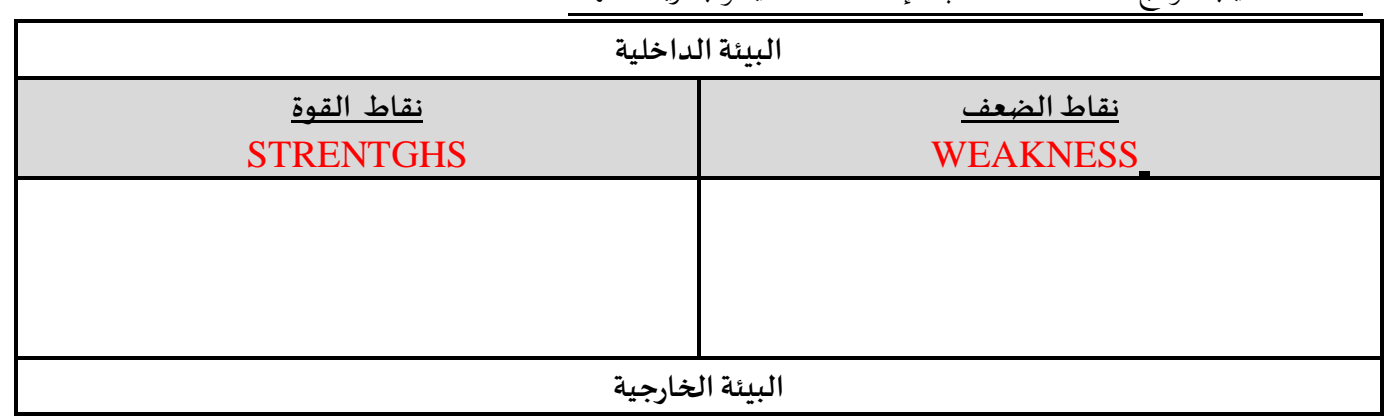




\section{ILA الجمعية المصرية للقراءة والمعرفة عضو الجمعية الدولية للمعرفة}

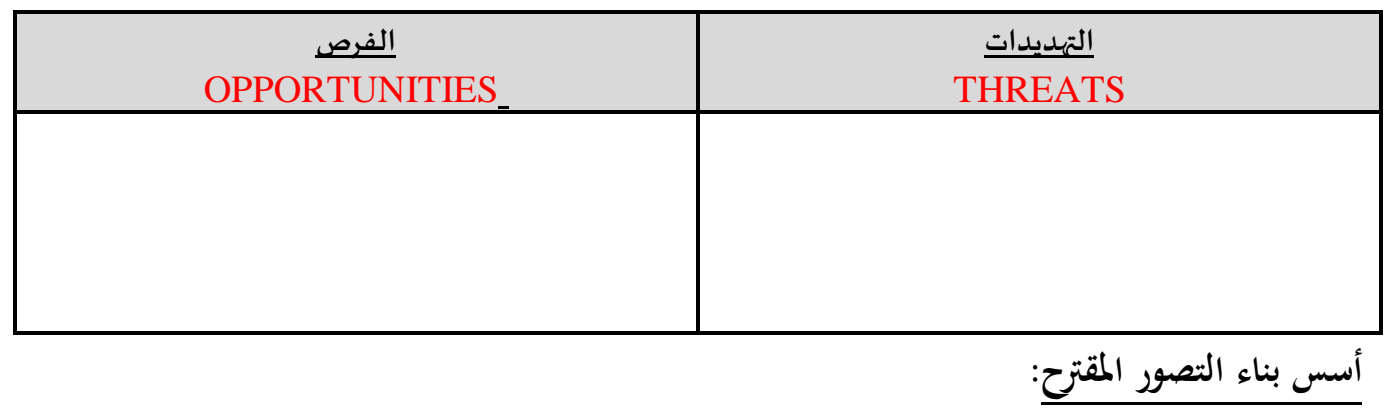

استند بناء التصور المقترح إلى ما يلي:

- مثيقة سياسة التعليم بالمملكة العربية السعودية. - - المراجعة التحليلية لوثائق رؤية المملكة العربية السعودية (2030). - - تحليل وتفسير نتائج إدارة التعليم في الاختبارات التحصيلية (المركزية) والاختبارات الوطنية والدولية لأأعوام السابقة.

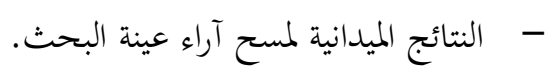
مبروات التصور المقتزح: من أهم المبررات التصور المقترح ما يلي: - - التوجه الرسمي لوزارة التعليم الذي أكد على الاهتمام بنواتج التعلم ورفع مستوى التحصيل الدراسي واتخاذ القرارات حول هذا الموضوع وقبولها والتوجيه بتنفيذها.

- - اهتمام الإدارة العامة للتعليم بمنطقة الباحة بنواتج التعلم وحرصها على رفع مستوى التحصيل الدراسي، وبناء الخطط الإجرائية على مستوى الإدارة ومكاتب التعليم والمدارس وتذليل الصعوبات التي قد تواجه الميدان أو تعيق عملية البناء والتنفيذ. - - ضعف نتائج الطلاب في الإدارة العامة للتعليم بمنطقة الباحة في الاختبارات التحصيلية (المركزية) والاختبارات الوطنية والدولية. - عيئة الميدان للاستعداد للاختبارات القادمة للوصول لنتائج متقدمة في كافة الاختبارات. 


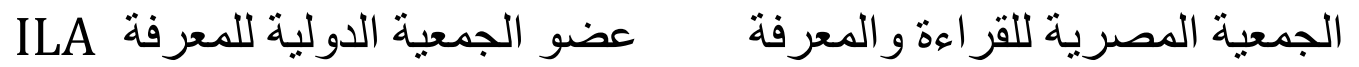

\section{يتطلب تنفيذ التصور المقترح عددًا من الإجراءات وتتمثل في الآتي:}

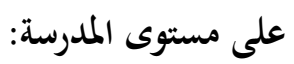

- - مشر ثقافة الاختبارات المركزية في مجتمع المدرسة.

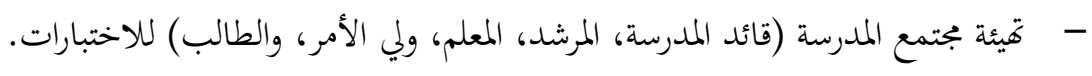

- - مقدير مجتمع المدرسة أهيّة الاختبارات المركزية.

- - تشكيل لجنة الاختبارات المركزية في المدرسة برئاسة قائد/ة المدرسة وعضوية كل من المنبارتهية (وكيل/ة،

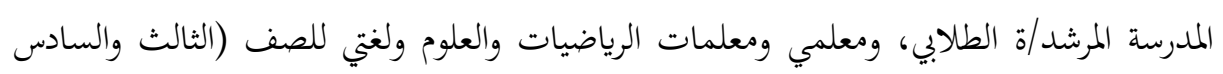
الابتدائي والثالث المتوسط) لمتابعة وتنفيذ آليات التطبيق.

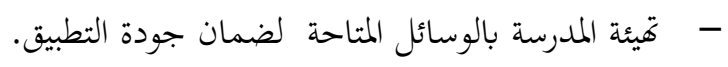

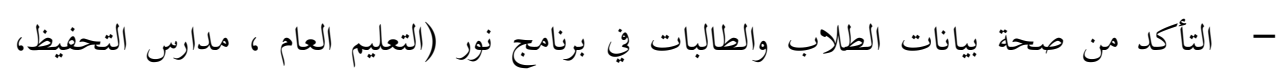

$$
\text { برنامج العوق السمعي، برنامج العوق البصري). }
$$

- - - تدريب المعلمين/ مات داخل المدرسة على إعداد اختبارات تحصيلية بمواصفات جيدة.

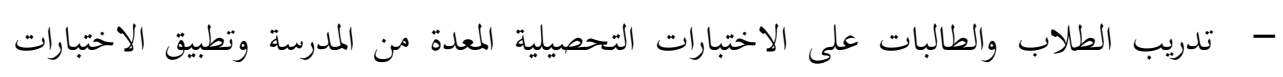

$$
\text { التجريبية المعدة من قبل الادارة. }
$$

- - التأكيد على الطلاب والطالبات بالحضور لأداء الاختبارات والجدية في الاجابة.

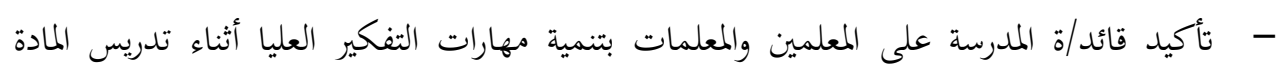

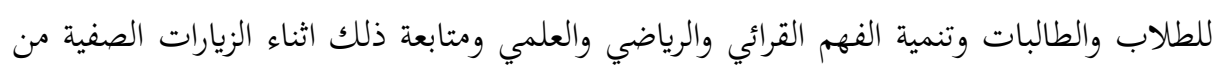

$$
\text { قبل المشرفين/ ات التربويين. }
$$

- - تخصيص برامج الاذاعة المدرسية للحديث حول الاختبارات المركزية. - - الاهتمام بالجوانب الفنية المتعلقة بآلية وسير الاختبارات وتصحيحها.

\section{على مستوى مكتب التعليم:}

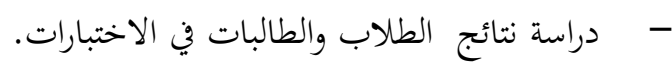
- - - تنمية الفهم القرائي لدى الطلاب والطالبات.

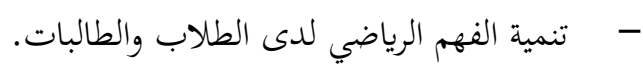
- - منمية المفاهيم العلمية لدى الطلاب والطالبات. 


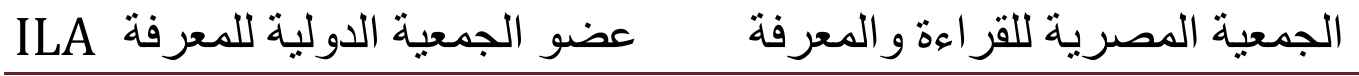

- - منعيل التعلم النشط من خلال استخدام مجموعة من الاستراتيجيات المتنوعة ومن خلال تشجيع

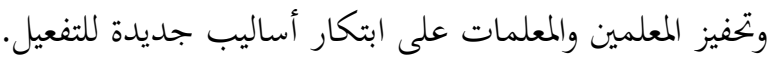
- - ملدريب الطلاب على نماذج من الاختبارات. - - مبيق اختبارات تحاكي الاختبارات التحصيلية.

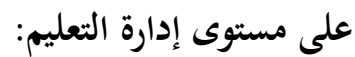

- مواجهة الملخصات والعمل بما يضمن استيفاء تدريس كافة مفردات المقررات الدراسية ومتابعة التنفيذ في المدارس ورفع تقارير دورية عن ذلك. تملكه

- - توفير بيانات كمية ونوعية عن نواتج التعلم وفقاً لاختبارات فهاية العام ، الاختبارات المركزية الوزارية ، الاختبارات المعدة من الإدارة، اختبارات قياس.

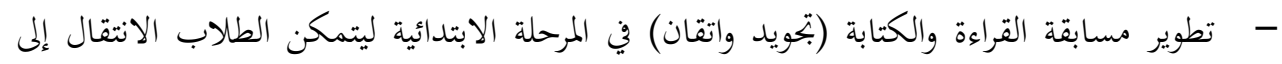
القراءة الناقدة، وبتويد مهارات الكتابة. - - حصر المبادرات النوعية وأفضل الممارسات التدريسية في الميدان من خلال إعداد معادية. معايير لعملية التقييم، والعمل على إبرازها وتعميمها بكافة الوسائل المتاحة. - - الإعلان عن مواعيد اختبارات القدرات والاختبار التحصيلي بكافة الوسائل. - - إقامة ملتقى لقادة وقائدات المدارس والمشرفين والمشرفات يتضمن المحاور الإجرائية التي تم الاتفاق عليها. - - - التدريب الكتابي لطلاب المرحلة الابتدائية وفق توجيه معالي الوزير.

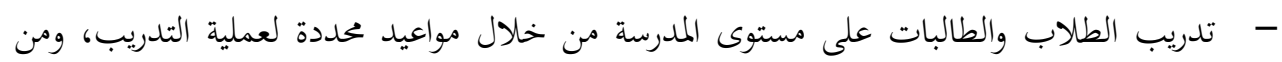
خلال إعداد حقائب تدريبية مبسطة في القراءة الناقدة، الكتابة المجودة (المرجلة الابتدائية)، مهارات التعلم الذاتي (للمرحلة المتوسطة والثانوية)، تدريب على نماذج من الاختبارات الدولية وفق الصفاف المستهدفة، التدريب على اختبارات القدرات، التدريب على الاختبارات التحصيلية.

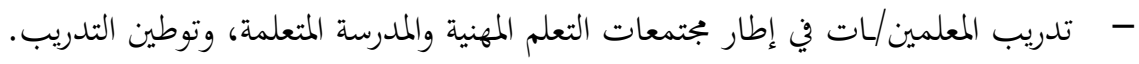

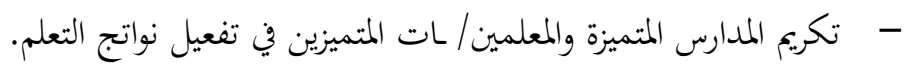

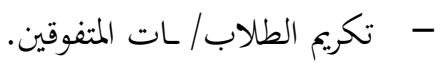




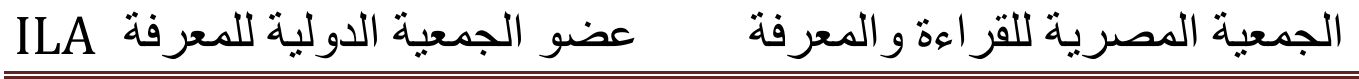

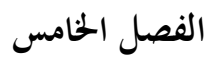

خاتمة البحث

تناول هذا الفصل ملخصًا للبحث، كما تناول التوصيات والمقترحات التي أسفرت عنها نتائج البحث

أولَا : ملخص نتائج البحث:

هدف هذا البحث إلى الإجابة عن الأسئلة الآتية:

1) ما أسباب تدني نتائج طلاب وطالبات المرحلتين الابتدائية والمتوسطة في الاختبارات التحصيلية

(المركزية) بمنطقة الباحة من وجهة نظر المعلمين والمعلمات والمشرفين والمشرفات بتعليم منطقة الباحة؟

2) ما التصور المقترح لمعالجة أسباب تدني نتائج طلاب وطالبات المرحلتين الابتدائية والمتوسطة في

الاختبارات التحصيلية (المركزية) بمنطقة الباحة؟

وقد تمت الإجابة عن أسئلة البحث.

حيث تم بناء استبانة لتحديد أسباب تدني مستوى التحصيل الدراسي تكونت من ثلاثة مجالات مجال المتعلم وبجال المعلم، وبجال البيئة المدرسية والصفية، طبقت على عينة مكونة من (754) معلماً ومعلمة وقائداً وقائدة ومشرفاً ومشرفة من منسوبي التعليم بمنطقة الباحة، تم اختيارهم بطريقة عشوائية.

وقد تم التوصل إلى النتائج التالية:

1) تدني عام في مستوى التحصيل الدراسي في الاختبارات التحصيلية (المركزية) لدى بعض الطلاب والطالبات بمنطقة الباحة، كما أشار البحث إلى أهم أسباب التدي وهي:

- - مجال المتعلم وهي: انشغال المتعلم بالأجهزة الذكية وبرامجها، إهمال المتعلم لمتابعة الدروس والواجبات المنزلية، وتدني الدافعية لدى المتعلم نحو التعلم.

- - مجال المعلم: إسناد تدريس المواد لغير المتخصصين، ضعف تطبيق أدوات التقويم المستمر للتعلّم عند المتعلمين، وضعف مهارة إثارة الدافعية. 


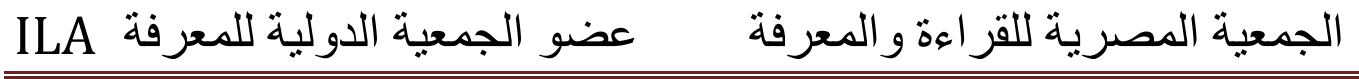

- - مجال البيئة المدرسية والصفية فقد كانت أهم الاسباب: ضعف البنية التحتية والمرافق المختلفة لممارسة الأنشطة التعليمية، عدم تفعيل معامل الرياضيات والعلوم، وعدم كفاية وسائل وتقنيات التعلم الداعمة للتدريس في البيئة الصفية.

2) توصل البحث لوضع تصور مقترح لمعالجة أسباب التدني شمل عدة إجراءات على مستوى المدرسة، ومكتب التعليم، وعلى مستوى إدارة التعليم.

\section{ثانيًا: توصيات البحث:}

في ضوء ما تم في هذا البحث من إجراءات، وما تم التوصل إليه من نتائج، يمكن أن يوصي البحث بما يلي:

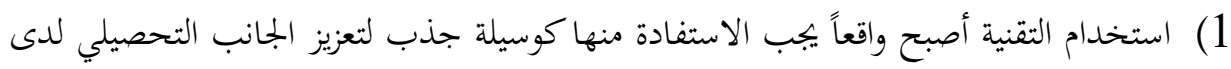
المتعلمين من خلال التطبيقات المساعدة على ذلك. 2) إعادة النظر في واقع تطبيق التعلم النشط لعدم وجود أثر يواكب ما يبذل من جهود. 3) إشراك المتعلم وولي الأمر في صنع القرار داخل المدرسة. 4) توجيه الجهود التي تمدف إلى رفع مستوى التحصيل الدراسي، ومتابعة الاختبارات المتنوعة تحت ظل إدارة واحدة. 5) التركيز على الممارسات داخل حجرة الصف والتقليل من الإجراءات الإدارية التي تعد عائقاً أم تحقيق الكثير من الأهداف. 6) تعزيز الشراكات المجتمعية لزيادة الوعي بأهمية التعلم. ثالثًا: مقترحات البحث: تنبثق من نتائج البحث الحالي بعض الدراسات المقترحة، منها: 1) إجراء دراسة مماثلة، تتضمن عينات عشوائية أكبر، مختارة من مجتمعات دراسية أخرى بمناطق ومدن المملكة العربية السعودية. 2) إجراء دراسة لتعرف التحاهات الطلاب والمعلمين نهو الاختبارات التحصيلية (المركزية). 3) ) إجراء دراسة لتعرف الفجوة بين نتائج الاختبارات المرحلية والاختبارات التحصيلية (المركزية). 4) إجراء دراسة لتعرف فاعلية الاختبارات التحصيلية (المركزية) في تحسين نواتج التعلم في مدارس التعليم 


\section{الجمعية المصرية للقر اعة والمعرفة عضو الجمعية الدولية للمعرفة}

\section{قائمة المر اجع}

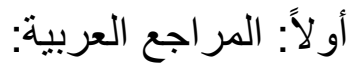

أبو دقة، سناء (2008). القياس والتقويم الصغي: المغاهيم والاجراءات لثعلم فعال، ط2. غزة: دار آفاق. أبو سعدة، رولا كمال تمُحَّم (2014). أثثر استخدام برنامج تدريسي يستند إلى البنائية في التحصيل وتنمية

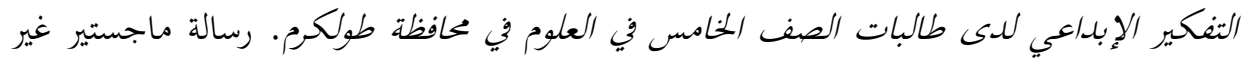

$$
\begin{aligned}
& \text { منشورة، جامعة النجاح الوطنية، كلية الدراسات العليا، فلسطين. } \\
& \text { أبو علام، رجاء محمود (2006). تقويم التعلم. عمان: دار المسيرة. } \\
& \text { آدم، بسماء (2004). قضية مدرسة وبيت وبجتمع.. التحصيل الدراسي. }
\end{aligned}
$$

بتاريخ: 2020/2/19

الأزوري، عبدالشكور مصلح (2015). العلاقة بين التصور البصري المكاني والتحصيل في مادة الرياضيات

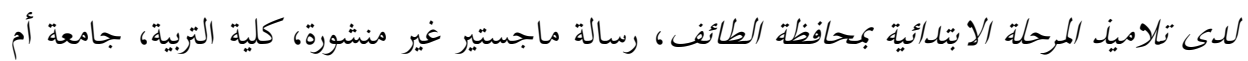

القرى، مكة المكرمة.

بشندي، خالد نُمَّمَ (2011). أثثر استخدام نموذج التعلم البنائي في تلدريس العلوم على التحصيل المعرفي وتنمية

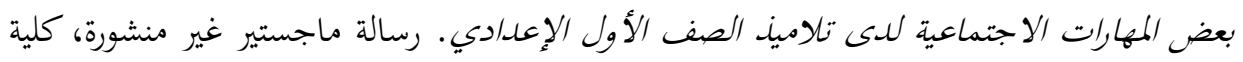
التربية، جامعة سوهاج، مصر.

حسنين، خوله يوسف (2011). فاعلية برنامج تعليمي قائم على التعلم المستند إلى الدماغ في تحسين

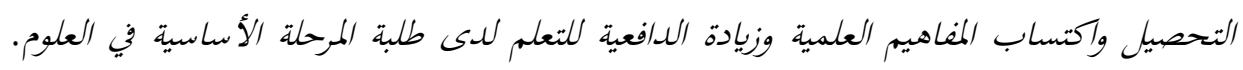
رسالة دكتوراه غير منشورة، الجامعة الأردنية، الأردن.

حمدان، مُحَّمَ (2008). معجمم مصطلحات التربية والتعليم. عمان: دار كنوز المعرفة. خلف الله، مروة (2013). فاعلية توظيف معمل الرياضيات في تنمية الهندسي والتحصيلي لدى طالبات

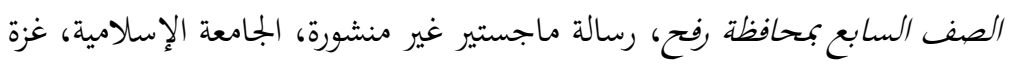

الخليلي، خليل يوسف؛ حيدر، عبداللطيف حسين؛ يونس، تُمَّمَ جمال الدين (2004). تدريس العلوم في مراحل التعليم العام. دبي: مكتبة دار التعلم. 


\section{الجمعية المصرية للقر اءة والمعرفة عضو الجمعية الدولية للمعرفة ILA}

دمنهوري، رشاد صالح (2006). التنشئة الاجتماعية والتأخر الدراسي، الاسكندرية: دار المعرفة الجامعية. دويك، نجاح أحمد مُجمَّم (2008). أساليب المعاملة الوالدية وعلاقتها بالنكاء والتحصيل الدراسي لدى الأطفال في مرحلة الطفولة المتأخرة، رسالة ماجستير غير منشورة، الجامعة الاسلامية بغزة، فلسطين. سعادة، جودت أحمد؛ إبراهيم، عبدالله مُحَّمَ (2014). المنهج المدرسي المعاصر. عمان: دار الفكر. السعيد، ممدوح (2009) فاعلية استخدام برنامج دروب الرياضيات للتعلم الالكتروني في التحصيل الدراسي لاسي

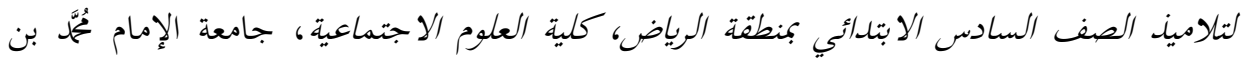

$$
\text { سعود الإسلامية، الرياض. }
$$

سمارة، نواف أحم؛ العديلي، عبدالسلام موسى (2008). مغاهيم ومصطلحات في العلوم التربوية. عمان: دار المسيرة.

الشايع، فهد سليمان (2010). أثر المدخل المنظومي على التحصيل الدراسي في العلوم والميول العلمية لدى

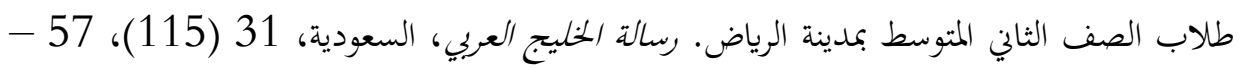

شحاته، حسن؛ النجار زينب (2003). معجم المصطلحات التربوية والنفسية. القاهرة: الدار المصرية اللبنانية. عبدالرمن، سعد (2003). القياس النفسي. ط4، القاهرة: دار الفكر العربي. عبد الهادي، جمال الدين توفيق (2004). تقويم كراسة التدريبات والأنشطة لمناهج العلوم بالمرحلة الابتدائية في

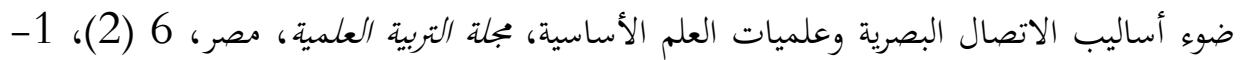

عبيدات، ذوقان؛ أبو السميد، سهيلة (2013). الدماغ والتعلم والتفكير. عمان: ديبونو للنشر والتوزيع. عطيو، تُمَّمَ نجيب مصطفى (2006). طرق تدريس العلوم بين النظرية والتطبيق. الرياض: مكتبة الرشد. عفانة، عزو إسماعيل؛ اللوح، أحمد حسن (2008). التدريس الممسرح (رؤية حديثة في التعليم). عمان: دار المسيرة.

علي، مُحمَّم السيد (2002). التربية العلمية وتدريس العلوم. القاهرة: دار الفكر العربي. 


\section{الجمعية المصرية للقر اءة والمعرفة عضو الجمعية الدولية للمعرفة ILA}

الغامدي، موفق علي أحمد (2016). فعالية أنموذج مقترح قائم على التكامل بين البنائية والتعلم المستند إلى المات

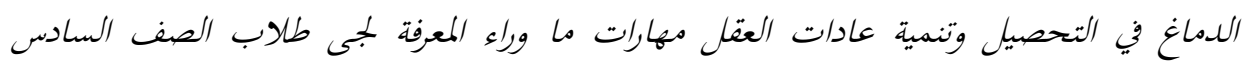
الابتدائي ، رسالة دكتوراه غير منشورة، جامعة الملك خالد الدية، السعودية.

فرمان، جلال عزيز السكماني، ذكاء عباس (2019). أثر استراتيجيتي التفكير بالمقلوب والتخيل الموجه في

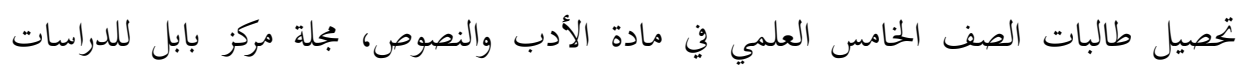

$$
\text { الإنسانية، } 9 \text { (4)، 233-264. }
$$

اللقاني، أحمد حسين؛ الجمل، علي أحمد (2003). معجم المصطلحات التربوية المعبرفة في المناهج وطرق التدريس، ط3. القاهرة: عالم الكتب.

ماجد، يوسف (2014). التحصيل العلمي: طرق التحصيل الدراسي. الإسكندرية: دار الكتب الجامعية. يُمَّمَ، مولاي بودخيلي (2004). نطق التحفيز المختلفة وعلاقتها بالتحصيل، الجزائر: ديوان المطبوعات الجامعية. ياسين، حاتم طه، عواد، حسن فهد (2019). أثر استراتيجية ثنائية التحليل والتركيب في تحصيل مادة

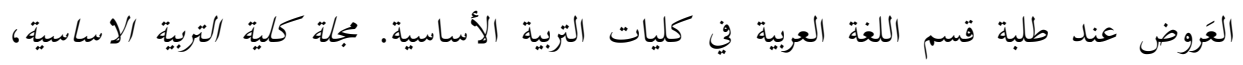
(104)25 
ثانياً: المراجع الأجنبية:

Avci, L. \& Yagbasan, L. (2009). Understanding a brain- based approach to learning and teaching. Educational Leadership, 48 (2), 66-71.

Carr, Jennie M. (2012). Does Math Achievement "h'APP'en" when iPads and GameBased Learning Are Incorporated into Fifth-Grade Mathematics Instruction? ,Journal of Information Technology Education: Research,v11:p269-286. http://eric.ed.gov. visit on 05/02/2020.

Tella, Adedeji(2013).The effect of peer tutoring and explicit instructional strategies on primary school pupils learning outcomes in Mathematics". Bulgarian Journal of Science and Education Policy (BJSEP), Vol.7, No.1: 5-25. http://bjsep.org/getfile.php?id=132. visit on 05/02/2020. 